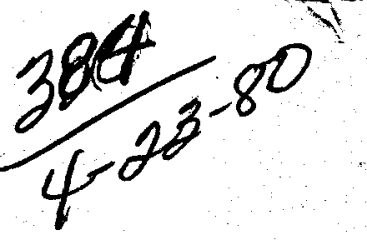

DOE/ET/28460-1(Vol.1)

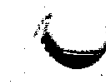

\title{
MASTER
}

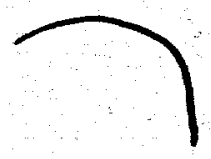

\section{INVESTIGATION AND EVALUATION OF \\ GEOPRESSURED-GEOTHERMAL WELLS}

Final Report; Fairfax Foster Sutter No. 2 Well

St. Mary Parish, Louisiana

Volume 1: Completion and Testing

By

M. H. Willits

R. L. McCoy

R. J. Dobson

J. H. Hartsock

MASTER

\section{December 1979}

Date Published

Work Performed Under Contract No. AC08-77ET28460

Gruy Federal, Inc.

Houston, Texas

U. S. DEPARTMENT OF ENERGY

Geothermal Energy

DISTRUBTION OF THIS DOEOMENT IS UNLIMIFERWT 


\section{DISCLAIMER}

This report was prepared as an account of work sponsored by an agency of the United States Government. Neither the United States Government nor any agency Thereof, nor any of their employees, makes any warranty, express or implied, or assumes any legal liability or responsibility for the accuracy, completeness, or usefulness of any information, apparatus, product, or process disclosed, or represents that its use would not infringe privately owned rights. Reference herein to any specific commercial product, process, or service by trade name, trademark, manufacturer, or otherwise does not necessarily constitute or imply its endorsement, recommendation, or favoring by the United States Government or any agency thereof. The views and opinions of authors expressed herein do not necessarily state or reflect those of the United States Government or any agency thereof. 


\section{DISCLAIMER}

Portions of this document may be illegible in electronic image products. Images are produced from the best available original document. 


\section{DISCLAIMER}

"This book was prepared as an account of work sponsored by an agency of the United States Government. Neither the United States Government nor any agency thereof, nor any of their employees, makes any warranty, express or implied, or assumes any legal liability or responsibility for the accuracy, completeness, or usefulness of any information, apparatus, product, or process disclosed, or represents that its use would not infringe privately owned rights. Reference herein to any specific commercial product, process, or service by trade name, trademark, manufacturer, or otherwise, does not necessarily constitute or imply its endorsement, recommendation, or favoring by the United States Government or any agency thereof. The views and opinions of authors expressed herein do not necessarily state or reflect those of the United States Government or any agency thereof."

This report has been reproduced directly from the best available copy.

Available from the National Technical Information Service, U.S. Department of Commerce, Springfield, Virginia 22161.

Price: Paper Copy $\$ 10.00$

Microfiche $\$ 3.50$ 
INVESTIGATION AND EVALUATION OF GEOPRESSURED-GEOTHERMAL WELLS

FINAL REPORT

FAIRFAX FOSTER SUTTER NO. 2 WELL ST. MARY PARISH, LOUISIANA

VOLUME I: COMPLETION AND TESTING

\author{
M. H. Willits \\ R. L. McCoy \\ R. J. Dobson \\ J. H. Hartsock
}

\author{
GRUY FEDERAL, INC. \\ 2500 Tanglewilde, Suite 150 \\ Houston, Texas 77063 \\ Date Published--December 1979 \\ Prepared for the \\ U.S. Department of Energy \\ Division of Geotherma 1 Energy \\ Under Contract No. DE*AC08-77ET28460
}




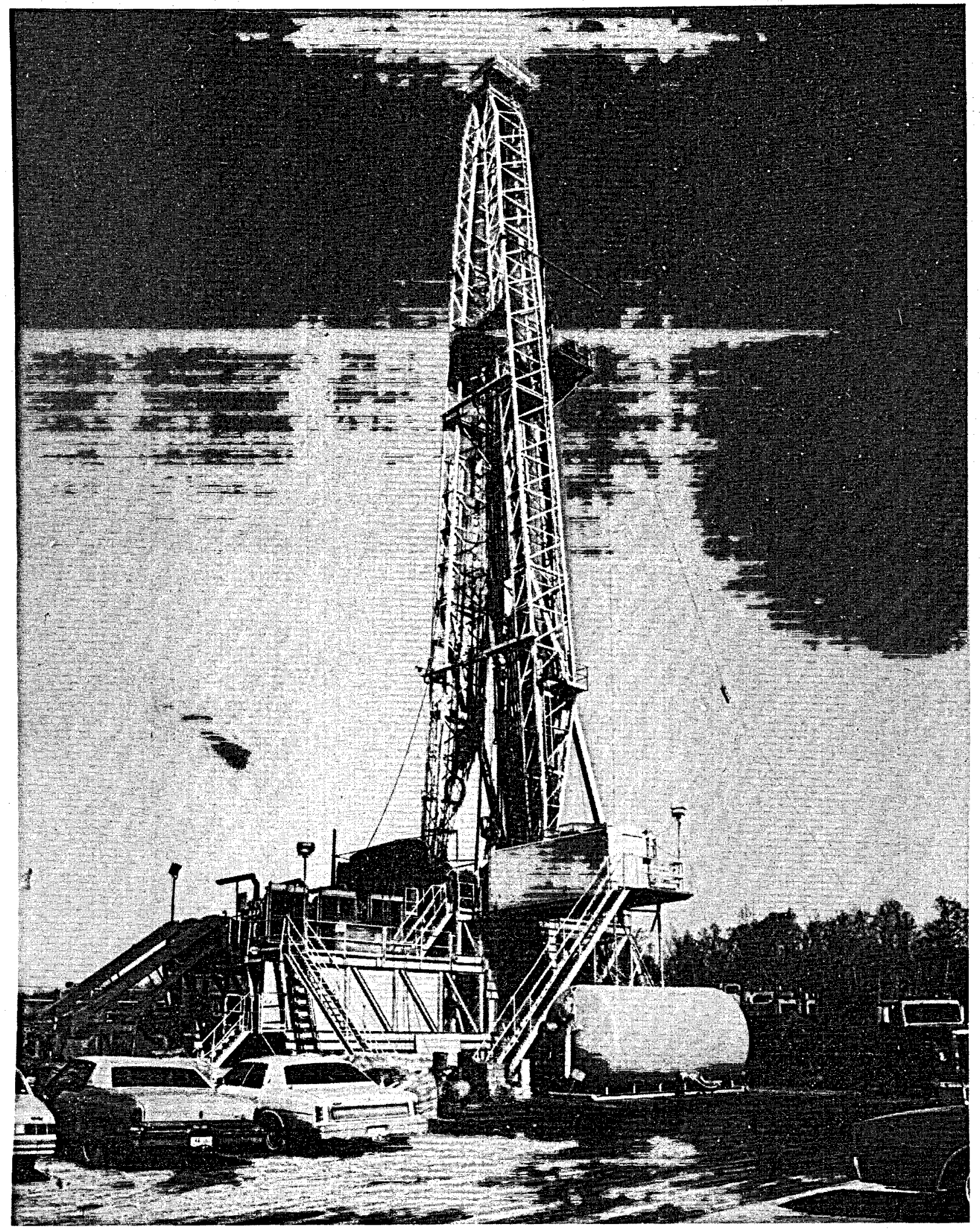

Goldrus Drilling Company Rig No. 15 on the Fairfax Foster Sutter No. 2 Well, St. Mary Parish, Louisiana. 


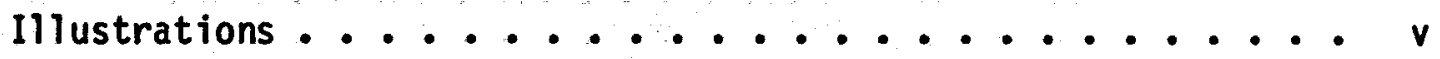

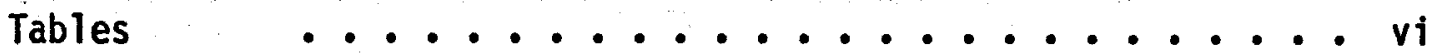

1.0 Executive Summary ................ vii

2.0 Introduction and Background ............ 1

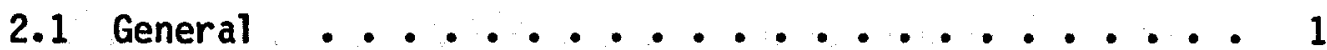

2.2 Geography ................. 2

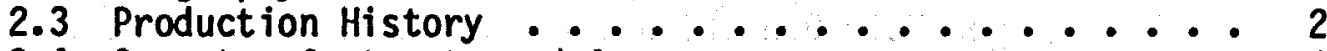

2.4 Operator Contracts and Agreements ........ 2

2.5 Drilling Contractor Agreements ......... 4

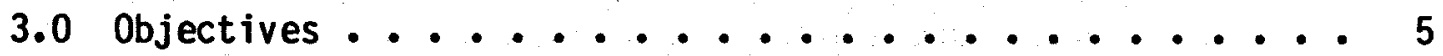

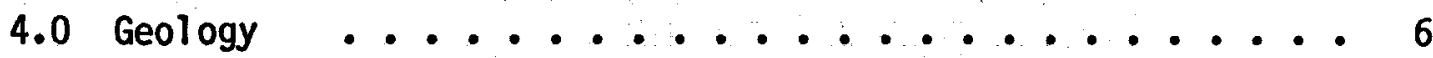

4.1 Regional Setting ............. 6

4.2 Local Geology ............... 6

5.0 Petrophysics .................... 14

5.1 Open-Hole Log Analysis - Test Well ....... 14

5.1 .1 Porosity ................ 14

5.1 .2 Net Thickness ............ 16

5.1.3 Reservoir Permeability .......... 16

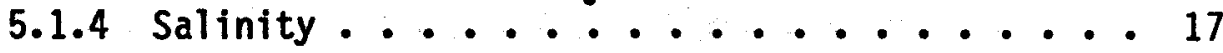

5.1.4.1 R Rethod ......... 17

5.1.4.2 SP-Derived $R_{\mathrm{w}} \ldots \ldots \ldots 19$

5.2 Open-Hole Log Analysis - Disposal Well ....... 20

5.3 Cased-Hole Log Analysis ........... 20

6.0 Drillsite and Support Facilities........... 21

6.0 .1 Site Layout ............ 21

6.0 .2 Living Quarters ............ 21

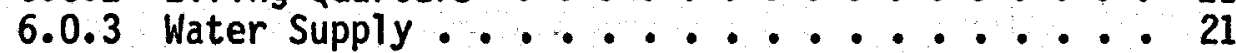

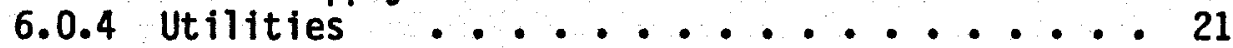

6.1 Test Well Design .............. 21

6.1.1 Initial and Anticipated Well

Completion Status .............. 21

6.1.2 Liner and Tubing Installation ....... 21 
Page

6.1.3 Wel thead Design ............ 25

6.1 .4 Logging Program ............. 25

6.1.4.1 Open-Hole Logs ......... 25

6.1 .4 .2 Cased-Hole Logs ........ 25

6.2 Drilling Operations: Test Well ........ 25

6.2.1 Blowout Preventers ........... 25

6.2.2. Drilling Fluids .............. 25

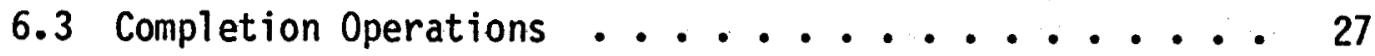

6.3.1 Open-Hole Operations ........... 27

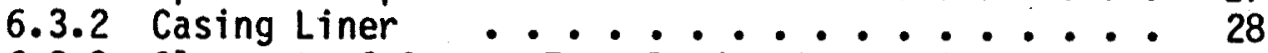

6.3.3 Cleanout of Cement From Production Casing .... 29

6.3 .4 Cased-Hole Logs ............... 30

6.3.5 Squeeze operations ........... 30

6.3.6 Completion Perforations .......... 32

6.3.7 Production Packer Setting ......... 32

6.3 .8 Production Tubing ............... 35

6.3.9 Christmas Tree ............ 36

7.0 Saltwater Disposal Well .................. 37

7.1 General $\ldots . . . . . . . . . . .37$

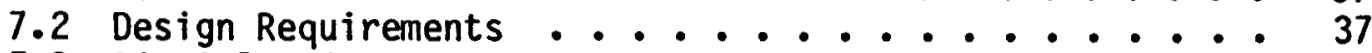

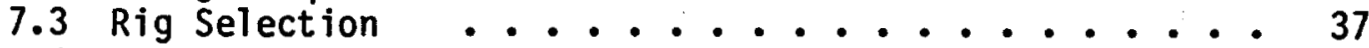

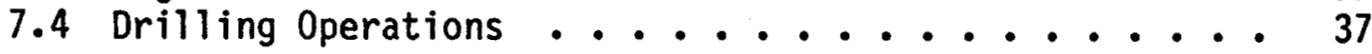

7.4.1 Conductor Casing ............. 37

7.4 .2 Surface Casing ............ 39

7.4.3 Completion Casing ............... 39

7.5 Completion Operations ..................... 39

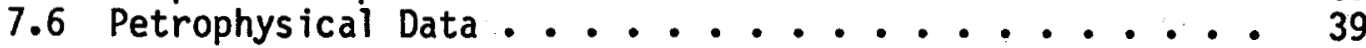

7.7 Perforation and Injectivity Tests ........ 40

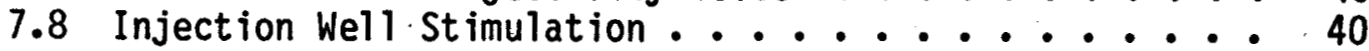

8.0 Test objectives .................... 43

9.0 Surface Testing Facilities ............ 44

9.1 Design ........................ 44

9.1 .1 Piping .......................... 44

9.1 .2 Separator .............. 44 44

9.1.3 Metering .............. 44 44

9.1.4 Air Cooler ............. 44

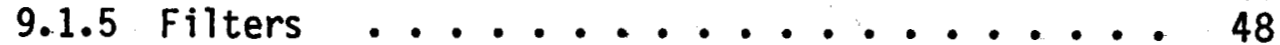

9.1 .6 Injection Pumps ............ 48

9.1.7 Safety Sensors ............ 48 
9.2 Data Collection .................... 48

9.3 Performance of Surface Equipment ......... 48

10.0 Pre-Test Operations .................. 51

10.1 Tubing Obstruction and Wellhead Problems ...... 51

10.2 Hewlett-Packard Gauge Problems .......... 52

11.0 Test Procedure ..................... 54

11.1 First Flow Test ............. 54

11.2 First Buildup Test ................. 54

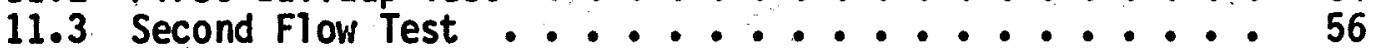

11.3.1 Hot Injectivity Test .......... 56

11.4 Final Buildup Test ................. 58

12.0 Test Analysis ....................... 59

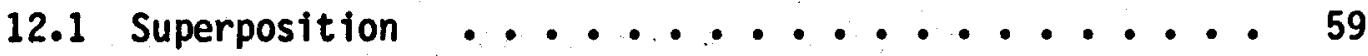

12.1.1 Rate Measurements ........... 59

12.2 Analysis of Second Buildup Data ......... 60

12.2.1 Intersecting Faults ........... 60

12.2.2 Parallel Faults ............ 60

12.3 Validation ......................... 63

12.4 Analysis of Second Drawdown Test ......... 63

12.4.1 Effect of Original Pressure ....... 65

12.5 Analysis of First Buildup Data ......... 65

12.6 Attempt to Compute Aquifer Volume ......... 68

12.7 Termination of the Flow and Buildup Tests ...... 68

12.8 Analysis of Gas and Liquid .......... 69

12.8.1 Chemical Analysis of Gas ........ 69

12.8.2 Chemical Analysis of Water ........ 69

12.8.3 Chemical Analysis of Scale ........ 73

12.8.4 PVT Analysis of the Recombined ........

Separator Sample ........... 73

13.0 Plugging and Abandonment .................. 78

13.1 Killing the Well ..................... 78

13.2 Operator Notification ................. 78

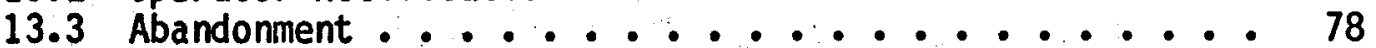


14.0 Conclusions ............................. 81

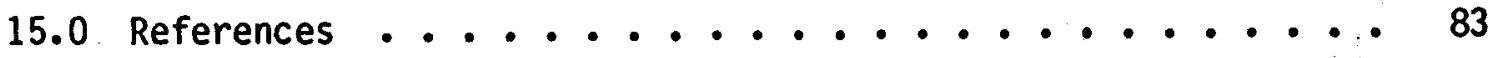

Appendix A, Test Well Drilling Contract .......... 85

Append ix B, Disposal Well Drilling Contract ......... 93

Appendix C, Report by Camco on Hewlett-Packard Gauge Fail ure ... 103

Appendix D, Theoretical Discussion of Superposition ....... 108 


\section{ILLUSTRATIONS}

Page

Figure 1 Location Map ................ 3

2 Structure Map, MA-6 Structure ......... 7

3 Cross-Section $B-B^{1} \ldots \ldots \ldots . \ldots . \ldots . . \ldots$

4 Structure, MA-6 Sand .................. 9

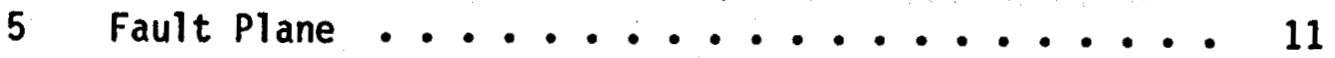

6 Thickness, MA-6 Sand ................ 12

7 Cross-Section A-A' ................. 13

8 Permeability vs. Sw irr $_{\text {for Porosity of } 19.3 \% \ldots \ldots} \ldots 18$

9 Schematic Location Plat . . . . . . . . 22

10 Schematic of Downhole Condition ........ 23

11-A Actual Welthead Design........... 26

11-B Future Wellhead Design ........... 26

12 Well Log Showing Perforation Interval ...... 33

13 Bottomhole Tubing Assembly .............. 34

14 Schematic for Disposal Well .......... 38

15 Injectivity Tests on Saltwater Disposal Well .... 41

16 Surface Facilities for Testing ......... 45

17 Pressure Production History During Test ..... 55

18 Pressure vs. Superimposed Time for Second Buildup . . 61

19 Bottomhole Pressure Minus Surface Pressure vs. Shut-in Time ................ 62

$20 \Delta p_{n} / q_{n}$ vs. Superimposed Time for Second Drawdown . . 64

21 Superimposed Rate - Time, Buildup No. $1 \ldots 66$

D-1 Schematic of Rate Variation Preceding

a Pressure Buildup ............. 113

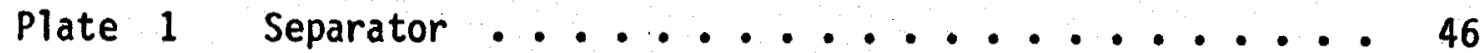

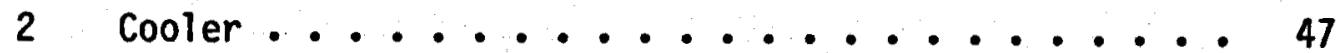

3 Data Collection Area ............ 49

4 Deadweight Tester ............ 57 


\section{TABLES}

Page

1 Tubular and Cementing Design Specifications ........ 24

2 Comparison of Amerada and Hewlett-Packard

Pressures Versus Depth .............. 53

3 Sumnary of Results of Reservoir Analysis ......... 67

4 Chemical Analysis of Gas ............. 70

5 Chemical Analysis of Produced Water .......... 71

6 Chemical Analysis of Produced Water (McNeese State University) ........... 72

7 Analysis of Scale ................... 74

8 Reservoir Fluid Properties of Water ......... 75

9 Pressure-Volume Relations of Well Stream at $270^{\circ} \mathrm{F} \ldots \ldots$

10 Nomenclature of P-V-T Symbols ........... 77

11 Analysis of Tubing Scale ............. 80 
The Fairfax Foster Sutter No. 2 well, located in the East Franklin area of St. Mary Parish, Louisiana, is the first successful test of a geopressured-geothermal aquifer under the Well-of-Opportunity program. Gruy Federal assumed operations on site on March 8,1978 , when the operator, Neuhoff $0 \mathrm{il}$ and Gas Company, abandoned the well as a dry hole at a total depth of 16,340 feet. Agreements with the operator, landowner, and drilling contractor were executed and the necessary permit applications were filed with the State of Louisiana and the Louisiana Department of Conservation.

The section tested was the MA- 6 sand of lower Miocene age which has produced large quantities of gas from the adjacent but structurally separated Garden City field. In Garden City this sand is characterized by pressure gradients of up to $0.94 \mathrm{psi} / \mathrm{ft}$ and reservoir temperatures in the $290^{\circ} \mathrm{F}$ $\left(143^{\circ} \mathrm{C}\right)$ range. In the subject well the observed temperature was $270^{\circ} \mathrm{F}$ $\left(132^{\circ} \mathrm{C}\right)$ and the measured gradient was $0.77 \mathrm{psi} / \mathrm{ft}$. The gross sand thickness was 270 feet, the net sand thickness 190 feet, and the tested interval 58 net feet.

While waiting on formal approval from the Department of Energy, operations were commenced to run and cement 2200 feet of 5-1/2 inch liner. Some problems were encountered in cementing the liner, in block squeezing the liner, and in the completion procedure which followed. Such problems, however, are not uncommon to conventional oil and gas field operations. A possible exception was the difficulty in releasing the liner and the corresponding tendency of the cement to set sooner than anticipated; thus some 4600 . feet of cement was left in the casing and had to be drilled.

The temperatures and pressures encountered approached the limits of the surface-recording bottomhole pressure gauge and particularly the single-conductor cables on which the gauges were run. Several failures were experienced initially, probably caused by wireline malfunctions. However, these downhole devices eventually became operational and important transient pressure data were recorded.

The objectives of the tests were all accomplished, and data were obtained which will contribute to the overall assessment of the geopressuredgeothermal resource of the Upper Gulf of Mexico basin. In general, the gas solubility $(22.8 \mathrm{scf} / \mathrm{bbl})$ was as expected for the temperature, pressure, and salinity of the brine. The produced water was more saline than expected $(160,000 \mathrm{mg} / 1)$. The high concentrations of dissolved solids, coupled with the evolution of $\mathrm{CO}_{2}$ from these waters during production, created a scaling problem in the tubular goods and surface equipment that will have to be addressed in future tests. 


\section{SUMMARY OF TEST RESULTS \\ Fairfax Foster Sutter No. 2 \\ East Franklin Area \\ St. Mary Parish, Louisiana}

TOTAL DEPTH: 16,340 feet

FORMATION: Marginulina ascensionensis (MA) 6 Lower Miocene

GROSS PERFORATIONS: $15,781-15,916$ feet

ORIGINAL RESERVOIR PRESSURE: 12,220 psia

ORIGINAL RESERVOIR TEMPERATURE: $270^{\circ} \mathrm{F}\left(132^{\circ} \mathrm{C}\right)$

AVERAGE POROSITY: 19\% (Formation density and compensated neutron logs)

TESTING:

Duration: 73 days including cleanup.

Tests: $\quad 3$-day drawdown

6.5-day buildup

11 day drawdown

19.5 day buildup

EFFECTIVE PERMEABILITY: $14.3 \mathrm{md}$ (Pressure transient tests)

GAS SOLUBILITY: 22.8 cubic feet per barrel

SAND PRODUCTION: None

SCALE FORMATION: Severe

ANALYSIS OF WATER:

Total Dissolved Solids - $203,475 \mathrm{mg} / 1$

Chlorides - $91,387 \mathrm{mg} / 1$

$\mathrm{pH}-6.18$

Density - $1.0932 \mathrm{gm} / \mathrm{cc}$

SuS Viscosity - 31.3

ANALYSIS OF GAS:

Methane 89.57 mol percent

$\mathrm{CO}_{2} \quad 7.85$ mol percent

AQUIFER GEOMETRY: Two parallel sealing faults 
2.0 INTRODUCTION AND BACKGROUND

2.1 General

During the latter half of the $1970^{\prime} s$ the demand for conventional energy in the United States has exceeded the supply from domestic sources. This shortfall was compounded by a decline in oil and gas productivity, reserves, and exploratory drilling; disruptions in the foreign supply followed by major price increases; and delays in the development of nuclear power and in conversion to coal for electrical generation under existing economic, sociological, and environmental constraints. Any appraisal of the energy choices facing this country cannot fail to conclude that all alternate sources must be assessed, evaluated, and, if economically viable, developed.

One such potential energy source consists of the porous geopressured sandstone reservoirs of Tertiary age encountered at depths generally below 10,000 feet in the Gulf Coast region of Texas and Louisiana. Several estimates have been made of the energy content of these reservpirs and of the energy recoverable under certain development scenarios. $1-5 *$ Such estimates are highly speculative, since no commercial or even experimental utilization of this potential energy source has ever been made. The U.S. Department of Energy (DOE) is conducting an extensive investigation of the thermal, hydrokinetic, and dissolved methane energy potentially available from such aquifers.

This report covers the acquisition, completion, and testing of a geopressured-geothermal (Geo ${ }^{2}$ ) well and reservoir by Gruy Federal, Inc. (Gruy) under a contract with the U.S. Department of Energy, Division of Geothermal Energy (DOE-DGE).** This contract, as extended, was in effect for the fiscal years 1978 and 1979. It provided for the "identification, qualification, acquisition, planning and conducting of geothermal-geopressured formation tests in up to six oil or gas wells, about to be drilled, being drilled, or being abandoned ...." The program is known as the "Well of Opportunity" (WOO) Program because the original concept was to take advantage of dry holes drilled by industry to obtain short-term test data on the methane content of the brines and the flowing characteristics of wellaquifer systems specifically designed to produce from rather than to avoid geopressured aquifers. Important monetary savings, at least 50 percent of the cost of drilling a new Geo test well, can be realized by taking over a well al ready drilled by others.

*References are listed in Section 15.

**Original contract No. EG-77-C-08-1528 between U.S. Energy Research and Development Administration (ERDA) and H. J. Gruy and Associates, Inc. dated September 14, 1977. 
This test was conducted on the well originally drilled as Neuhoff 0il and Gas Corporation Fairfax Foster Sutter No. 2 well in St. Mary Parish, Louisiana. This was an outstep exploratory well in the East Franklin gas field which failed to encounter commercial hydrocarbons. As described in this report, Gruy acquired use of the wellbore, tested a zone with no known gas accumulation updip, and returned the hole to the operator.

\subsection{Geography}

The Fairfax Foster Sutter No. 2 location is contained within the Alice C. Plantation, a large and historical agricultural enterprise largely engaged in growing sugar cane. The location is in T-15-S, R-10-E, St. Mary Parish, La., approximately four miles east of the town of Franklin. It is accessible by State Highway 87 and a short stretch of oyster shell and board roads (see Fig. 1). The terrain is flat and low-lying, subject to flooding, but the well was drilled as a land location in an area of extensive marshes and inland waterways. Bayou Teche lies less than a mile to the south.

\subsection{Production History}

The well site is associated with the East Franklin gas condensate field, where three wells produce from the MA-4 and MA-5 (Miocene) sand series at approximately 15,000 feet. The highly productive Garden city gas field lies some 3 miles to the south. Garden city is notable as one of the earliest deep geopressured gas fields capable of sustained production at high rates without the rapid decline in reservoir pressure and producibility commonly associated with geopressured reservoirs up to that time. This was one factor in the selection of the general area for a $\mathrm{Geo}^{2}$ test well search.

As of January 1, 1979, the MA-6 reservoir has produced 119 billion cubic feet of gas at Garden City, which indicates fair to good continuity, areal extent, and sand development. The East Frankl in field is separated from the Garden City field by faulting and a structural saddle. The MA-6 sand has not been found to contain gas in East Franklin.

\subsection{Operator Contracts and Agreements}

Neuhoff 0 il \& Gas Corporation (Neuhoff) and associates are the principal working interest owmers of a 15,482-foot well drilled in late 1978 at a location some 2000 feet to the east of the subject well. This well, styled as Alcorn Production Company et al Fairfax Foster Sutter No. 1, was offered to Gruy Federal as a WOO prospect should it prove to be a dry hole. The offer was withdrawn when the MA-4 and MA-5 sands at 14,75914,794 and 14,989-15,037 feet showed commercial gas condensate accumulations.

Because of the cooperative posture of Neuhoff, the progress of the second and subject well, Fairfax Foster Sutter No. 2, was closely monitored. The surface and mineral owners were equally cooperative. Thus when the operation resulted in a dry hole it was possible to conclude verbal negotiations with both parties within the day of notification. 


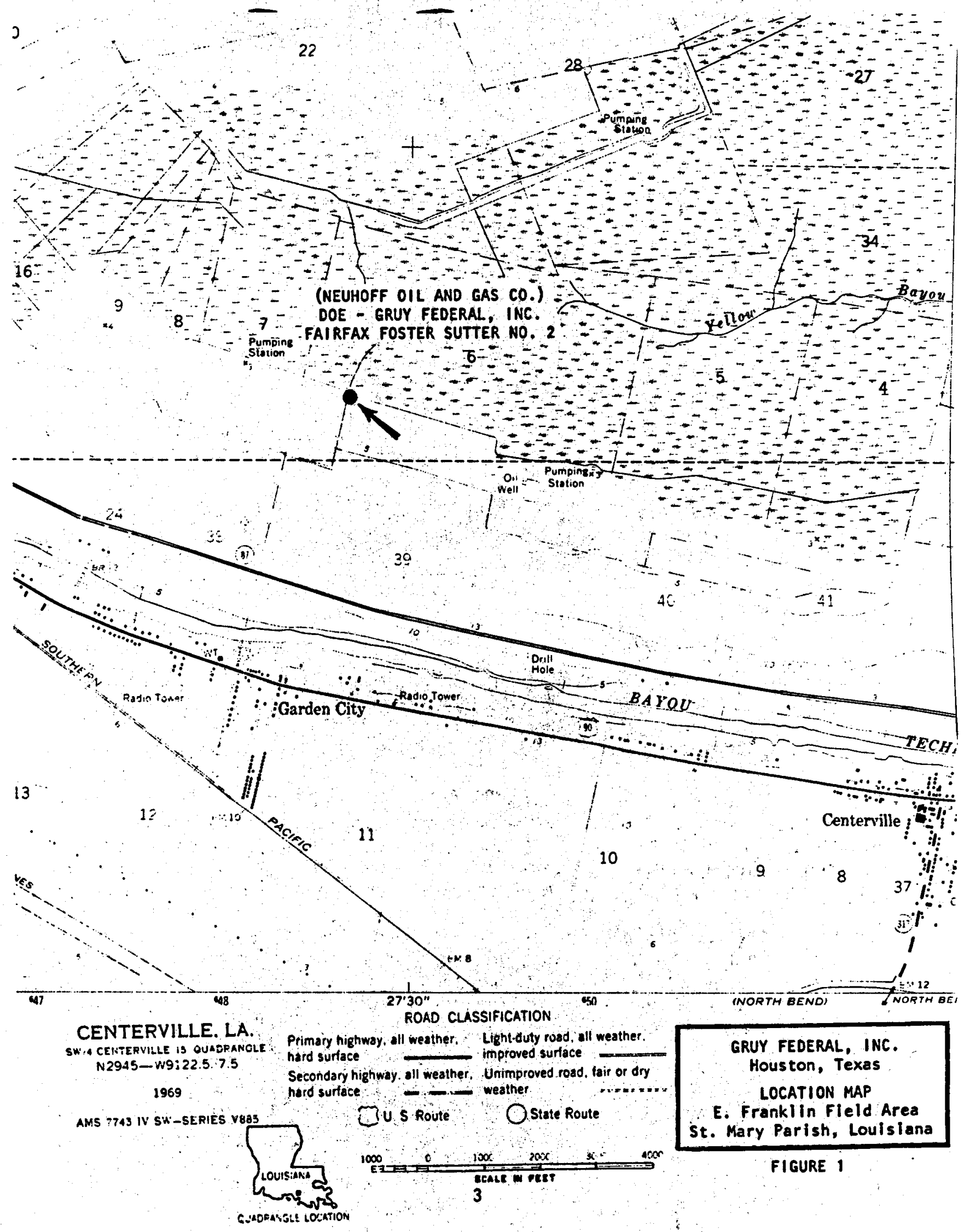


Notification of the dry hole was received on the morning of March 7, 1979. Tentative agreement was reached with the operator by phone. A formal contract, subject to DOE approval, was executed the following day.

In Louisiana it is considered necessary to obtain permission of the land and mineral owners to conduct Geo testing, since geothermal rights have been severed from conventional oil and gas rights unless specifically covered by a lease agreement. (This is true of State lands and can be construed to apply to private lands). A verbal agreement was obtained on March 7 providing for testing rights and a payment to the land and mineral owners. This was possible because of earlier contacts relating to the Alice C. Plantation No. 2 reentry attempt and the Alcorn-Fairfax Foster Sutter No. 1 well.

Verbal approval was obtained from DOE on March 7. to pay standby time for the drilling rig and to proceed with installation of a liner to protect the open hole. The next day, following receipt of a Gruy proposal, DOE/ Nevada Operations Office confirmed approval of this expenditure. Meanwhile, Gruy prepared a formal proposal for the entire project, estimating a cost of approximately $\$ 1.5$ million exclusive of overhead and fixed fee charges. The project was approved by the DOE on March 19, 1979.

\subsection{Drilling Contractor Agreements}

A verbal agreement to engage the drilling contractor on location, Goldrus Drilling Company, was made on March 7 and confirmed by contract on March 9. A copy of this contract is incluided in Appendix A. The same hourly rates in effect with Neuhoff became effective. Goldrus Rig No. 15 performed the $\mathrm{GeO}^{2}$ completion operations, consisting of installing and cementing a 5-inch liner, squeeze-cementing and testing the liner, perforating for completion, running tubing, and installing wellhead connections. These operations are described el sewhere in this report.

A photograph of Goldrus Rig No. 15 provides the frontispiece of this report. 


\section{$3.0 \quad$ OBJECTIVES}

The "Well-of-Opportunity" progran was designed to obtain short-term test data from several geopressured-geothermal aquifers in different geologic environments along the Gulf Coast region of Texas and Louisiana. The task required not only expertise in drilling, completing, and testing the wells and interpreting physical data from these aquifers, but al so a knowledge of the regional geology, effective communication and close coordination with oil and gas operators, and a scouting system capable of finding the deep wells and following their progress during drilling.

As stated in the Request for Proposal6 dated April 1, 1977, the objectives of the geopressured well tests are to obtain data related to:

- The aquifer fluid properties including in-situ temperature, chemical composition, hydrocarbon content, and pressure.

- The characteristics of geopressured geothermal reservoirs including permeability, porosity, extent and distribution of sands and shales, degree of compaction and rock composition.

- The behavior of fluids and the reservoir under conditions of fluid production at moderate and high flow rates, including pressure-time behavior at different flow rates, fluid characteristics under varying production conditions, and other information related to the reservoir production drive mechanisms and physical and chemical changes that may occur with various production conditions.

- The evaluation of completion techniques and production strategies for geopressured-geothermal wells.

Without exception the test on the Fairfax Foster Sutter No. 2 well was successful in accomplishing all the goals established for this program. 


\subsection{Regional Setting}

The Fairfax Foster Sutter No. 2 well was tested in the Marginulina ascensionensis (MA) 6 zone of lower Miocene age. In this area the MA section is a blanket sand body deposited in an inner neritic (shallow marine) environment during a regressive stage.

Geopressures are encountered throughout the area, requiring protection pipe to be set to approximately 14,500 feet $(+300$ feet). The transition zone extends through the MA-4 zone. Drilling mud weights indicate that 1 arge pressure gradients $(0.76$ to $0.94 \mathrm{ps} / \mathrm{ft})$ are encountered in the MA-5 and older sections.

Log recorded temperatures in the geopressured zones range from $220^{\circ}$ to $290^{\circ} \mathrm{F}\left(104-143^{\circ} \mathrm{C}\right)$, averaging $263^{\circ} \mathrm{F}\left(128^{\circ} \mathrm{C}\right)$ at 16,000 feet, The average gradient based on $27 \mathrm{log}$ data points through the $\mathrm{GeO}^{2}$ horizons is $2.67^{\circ} \mathrm{F} / 100 \mathrm{ft}\left(48.5^{\circ} \mathrm{C} / \mathrm{km}\right)$.

The MA section has been differentiated through the MA-6 in the Frankl in area, but in the Garden City area is further differentiated through the MA-12 (Exhibit 6 of Docket No. 65-157, Loulsiana Department of Conservation). In fact, gas is produced in the Garden City field from both the $M A-11$ and MA-12 reservoirs.

Growth-type faulting predominates in the area, creating anomalies in observed gas-water levels in adjacent wells. This was observed in the MA-5 reservoir in the Frankl in area, where the Franks-Petro Funds W. P. Foster No. 2 well produced gas from the MA-5 sand at a structural elevation of 15,320 feet subsea; the Arco W. P. Foster No. 1 produced gas from the MA-5 at 15,554 feet subsea, but the Neuhoff-Fairfax Foster Sutter No. 2 well was water-bearing at 15,106 feet subsea.

Figure 2 is a regional structural interpretation of the MA-6 sand showing the relationship between the Franklin area, where the MA-6 is nonproductive, and the Garden City area, where 119 BCf of gas has been produced through January 1, 1979. In Fig. 3, Section B-B' shows the gross stratigraphic relationships and fault cut points and displacements.

The Garden City field is located on the crest of a northwest-southeast oriented anticline which is effectively truncated to the southeast by the facies change (sand to shale) of the MA-6 as it extended into a deeperwater, lower-energy depositional environment (prior to structuring), and by a regional down-to-coast growth fault.

\subsection{Local Geology}

The dominant structure of the Franklin area is essentially a domal uplift truncated to the north by a large regional growth-type fault (Fig. 4) and to the south by a smaller bifurcating fault. The larger fault $(A)$ is evidenced by cut points in the following wells: 


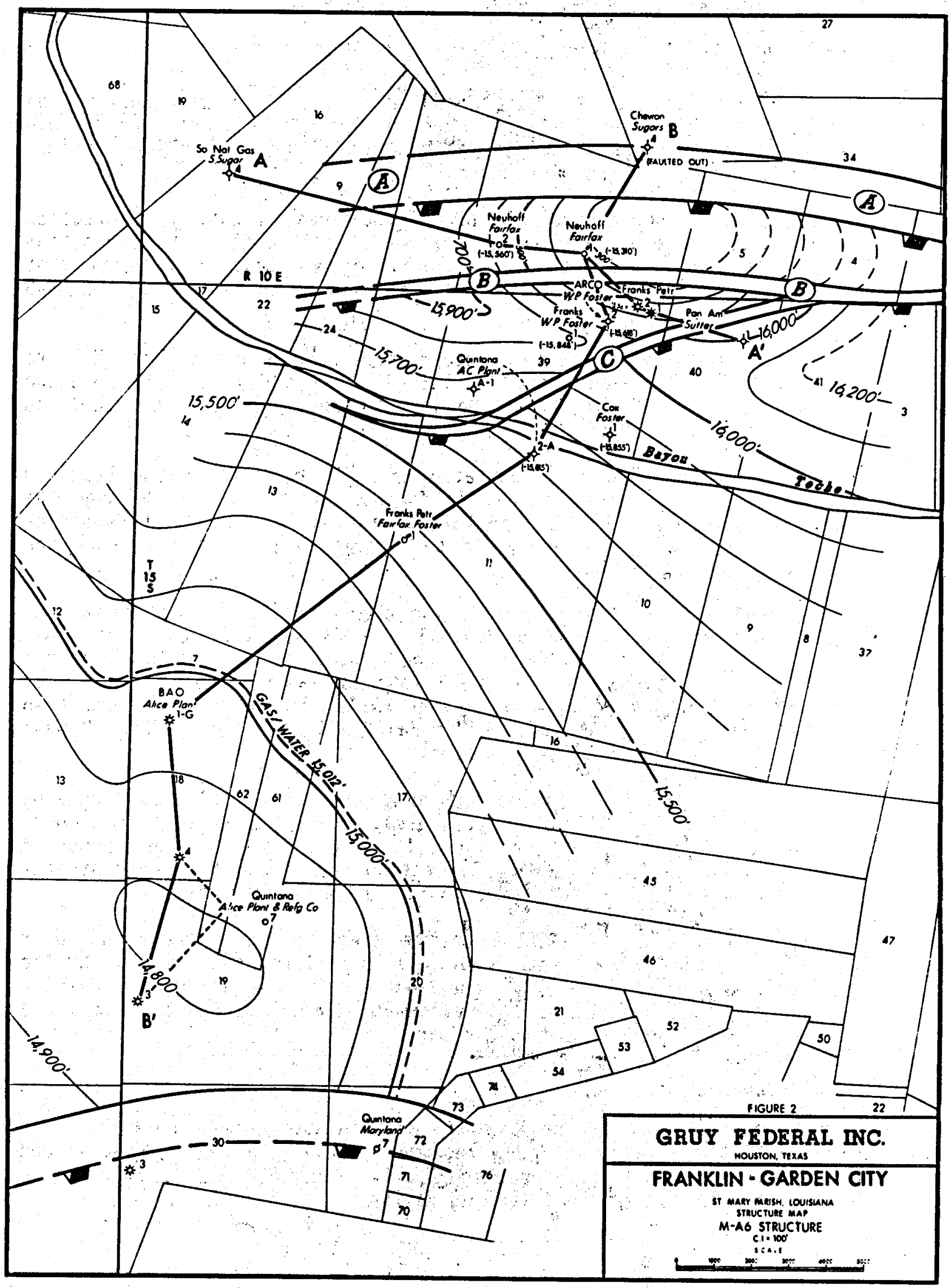




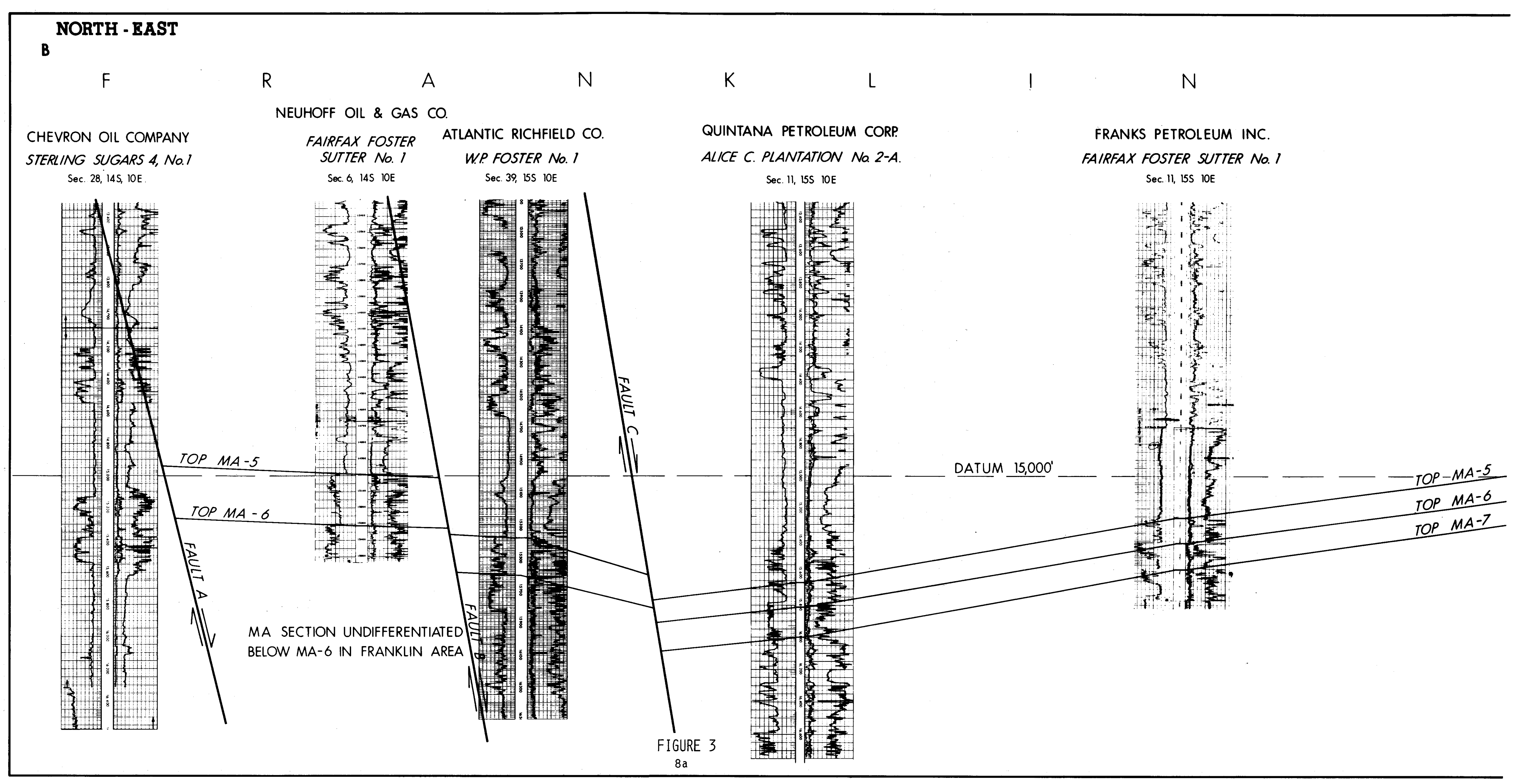



G
A $\quad R$
D
E
N
$\begin{array}{llll}C & \text { I } & T & Y\end{array}$
SOUTH - WEST

BRITISH AMERICAN OIL PROD. CO.

QUINTANA PETROLEUM CORP. ALICE C. PLANTATION \& REFINING CO. No.I Sec. 18, 15S $10 \mathrm{E}$ ALICE C. PLANTATION NO. 4 Sec. 18, $15 S$ DOE

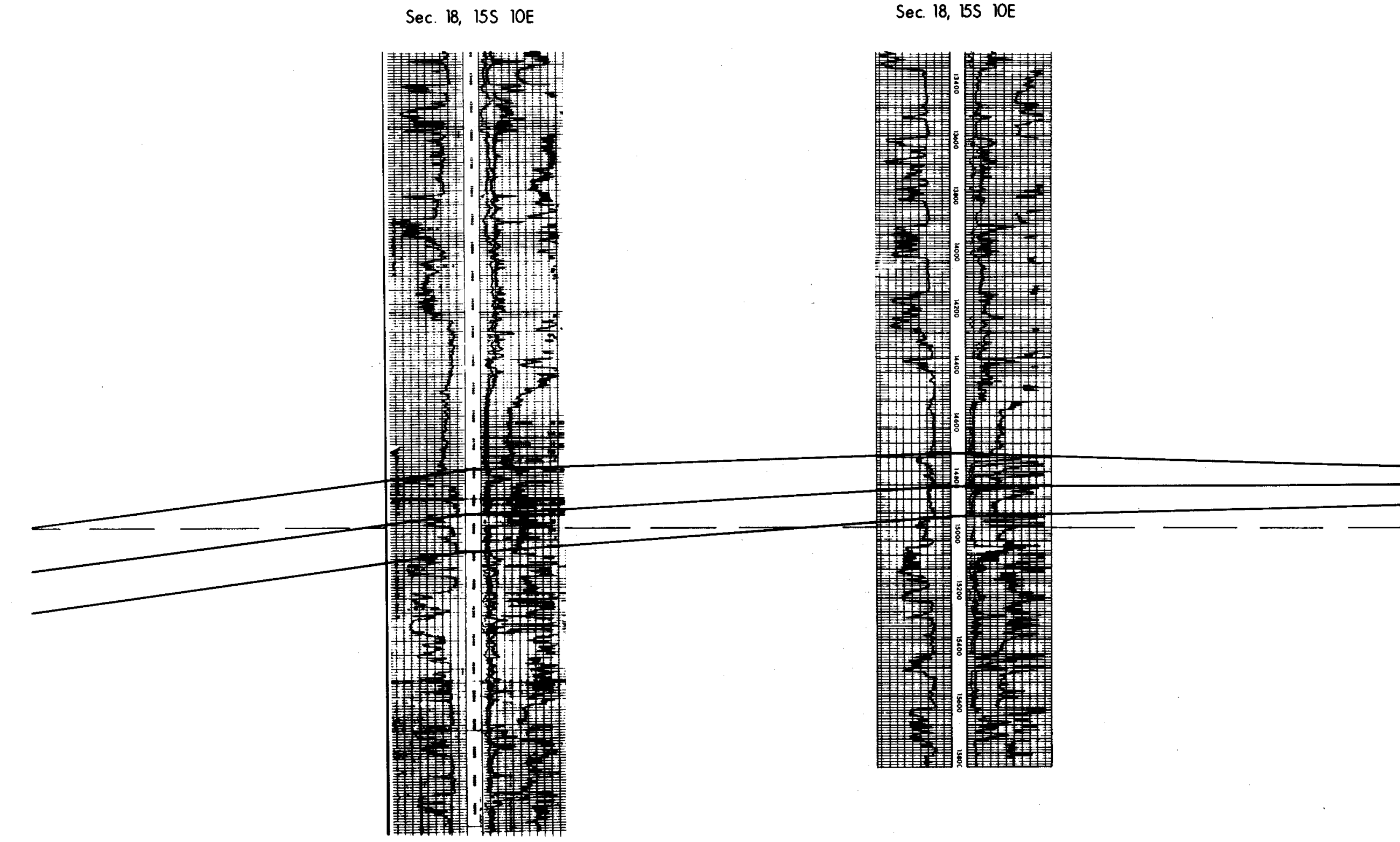

QUINTANA PETROLEUM CORP

ALICE C. PLANTATION \& REFINING CO. No.3 Sec. 19, 15S, $10 \mathrm{E}$

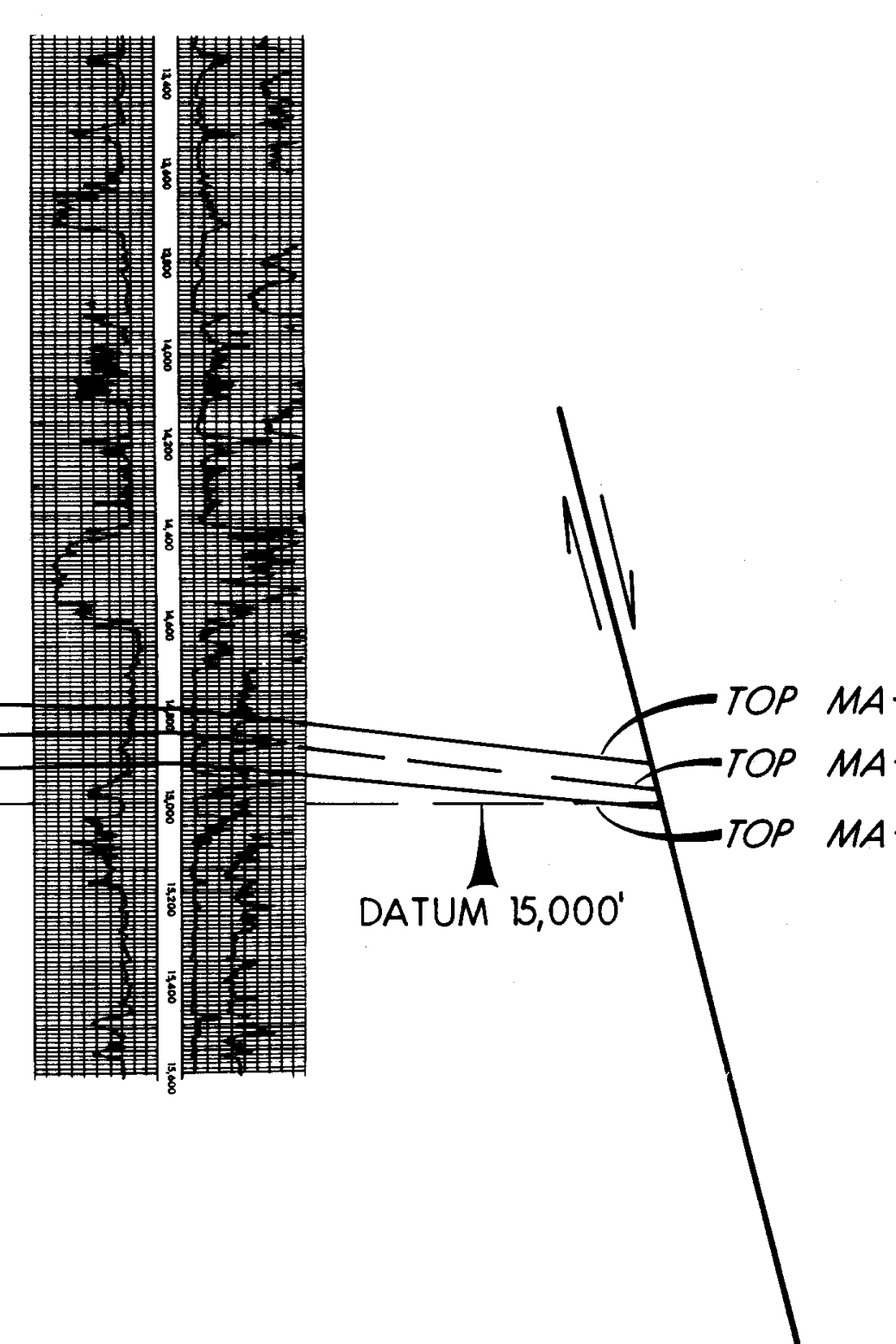

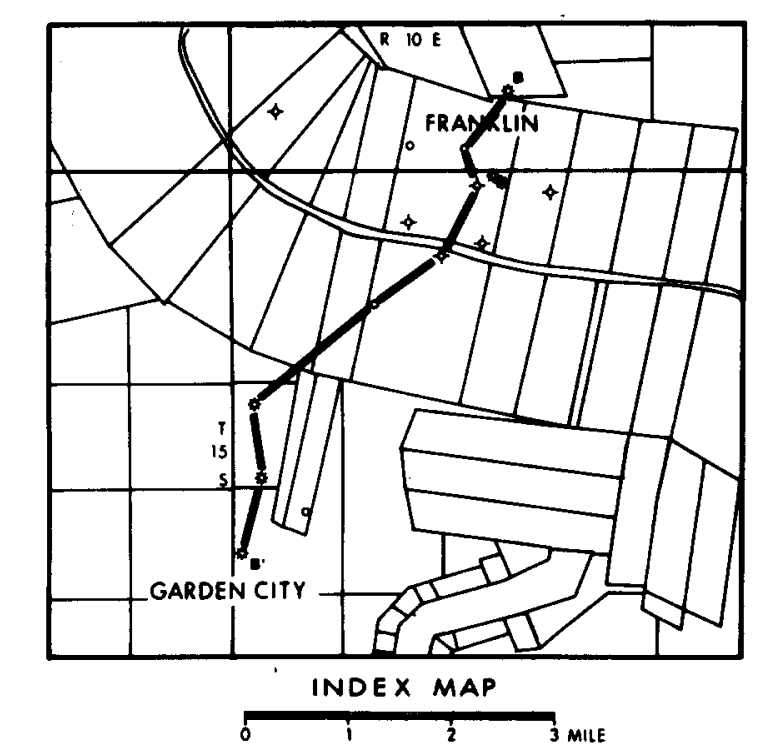

FRANKLIN - GARDEN CITY AREA ST. MARY PARISH, LOUISIANA CROSS - SECTION B-B'

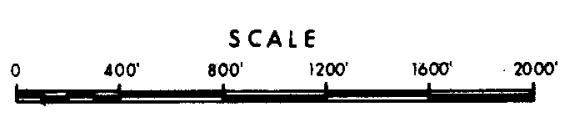




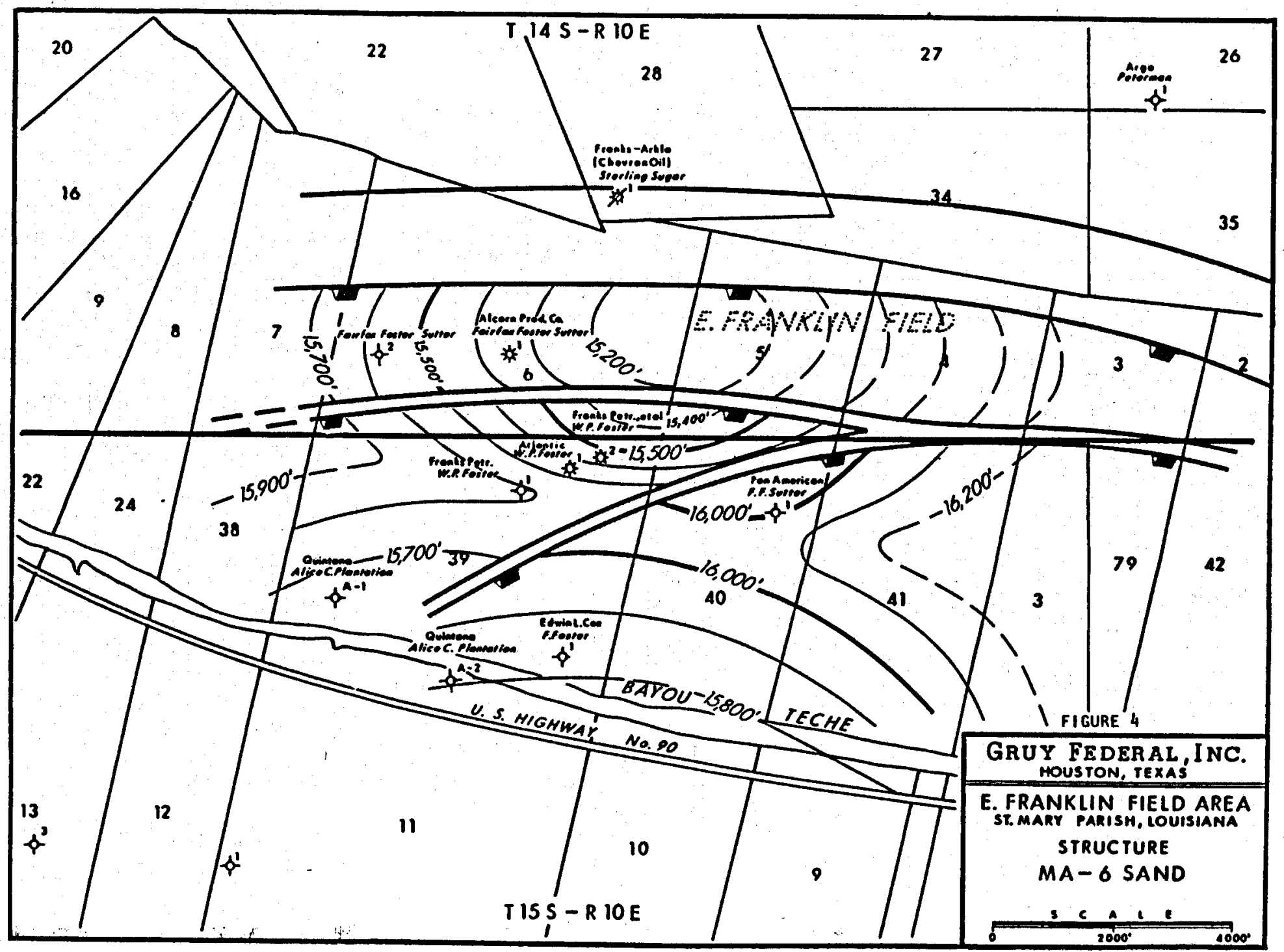


1. Chevron, Sterling Sugars $1-4$ at 13,550 feet

2. Southern Natural Gas $A-1$ at 13,700 feet

3. Brown, Sterling Sugars No. 1 at 12,630 feet

Fault B was evidenced by anomalies in the gas/water contacts encountered in the MA-5 zone as well as cut points in the Neuhoff-Fairfax Foster Sutter Nos. 1 and 2. A small bifurcation (Fault C) was picked in three wells (Fig. 5). Although control is limited in the trough between the Frankl in and Garden City structures, Fault $C$ appears simply to die out as it comes off structure. This would tend to indicate that it is a stressrelief type fault associated with the domal structuring, and probably occurred during deep-seated salt piercement.

As indicated in Fig. 4, the test well is approximately 1100 feet south of Fault $A$ and approximately 900 feet north of Fault B. The greatest MA-6 sand thickness observed was at the test well location. Seven wells in the Franklin area penetrated the MA-6 section. This limited control, further complicated by the faulting, does not provide sufficient information to construct a reliable net sand isopach. It is, however, evident that the sand development is greatest to the west coming off structure (Fig. 6).

The test well had a maximum log recorded temperature of $277^{\circ} \mathrm{F}\left(142^{\circ} \mathrm{C}\right)$ at 16,348 feet. Using the regional $\mathrm{Geo}^{2}$ temperature gradient of $2.67^{\circ} \mathrm{F} / 100$ ft $\left(48.5^{\circ} \mathrm{C} / \mathrm{km}\right)$, this equates to $264^{\circ} \mathrm{F}\left(129^{\circ} \mathrm{C}\right)$ for the MA-6 test interval. The AAPG correction factors, which have been used in the past to correct wellbore to true formation temperatures, would correct this value to approximately $294^{\circ} \mathrm{F}\left(146^{\circ} \mathrm{C}\right)$. Analys is of produced fluids $\left(270^{\circ} \mathrm{F}, 132^{\circ} \mathrm{C}\right)$, however, indicates that this type of correction may not be justified because the empirical relationship ignores the time since fluid circulation ceased. Hence, the log-recorded bottomhole temperature may be a reasonably accurate measure of the aquifer temperature for these deep wells. 


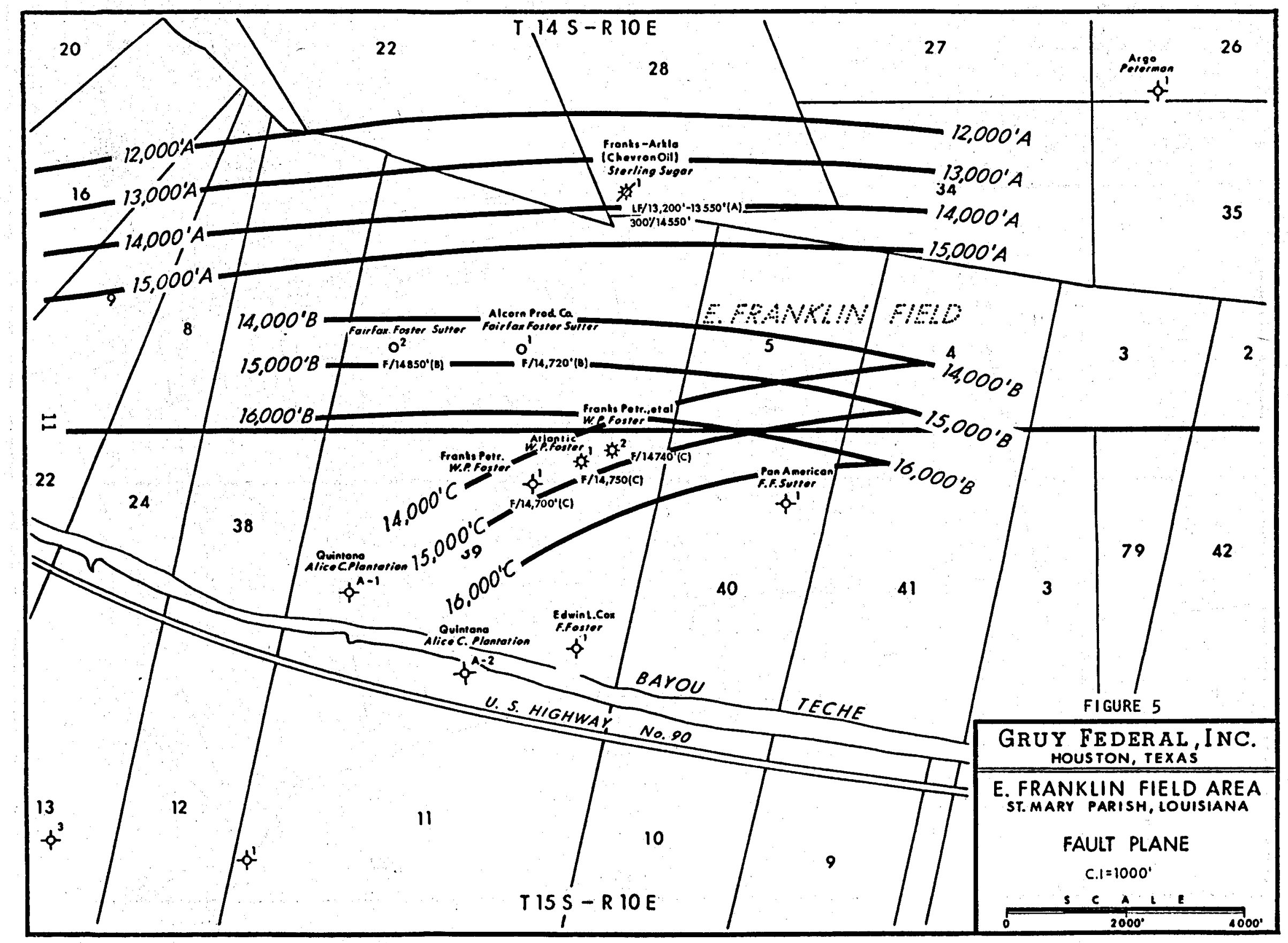




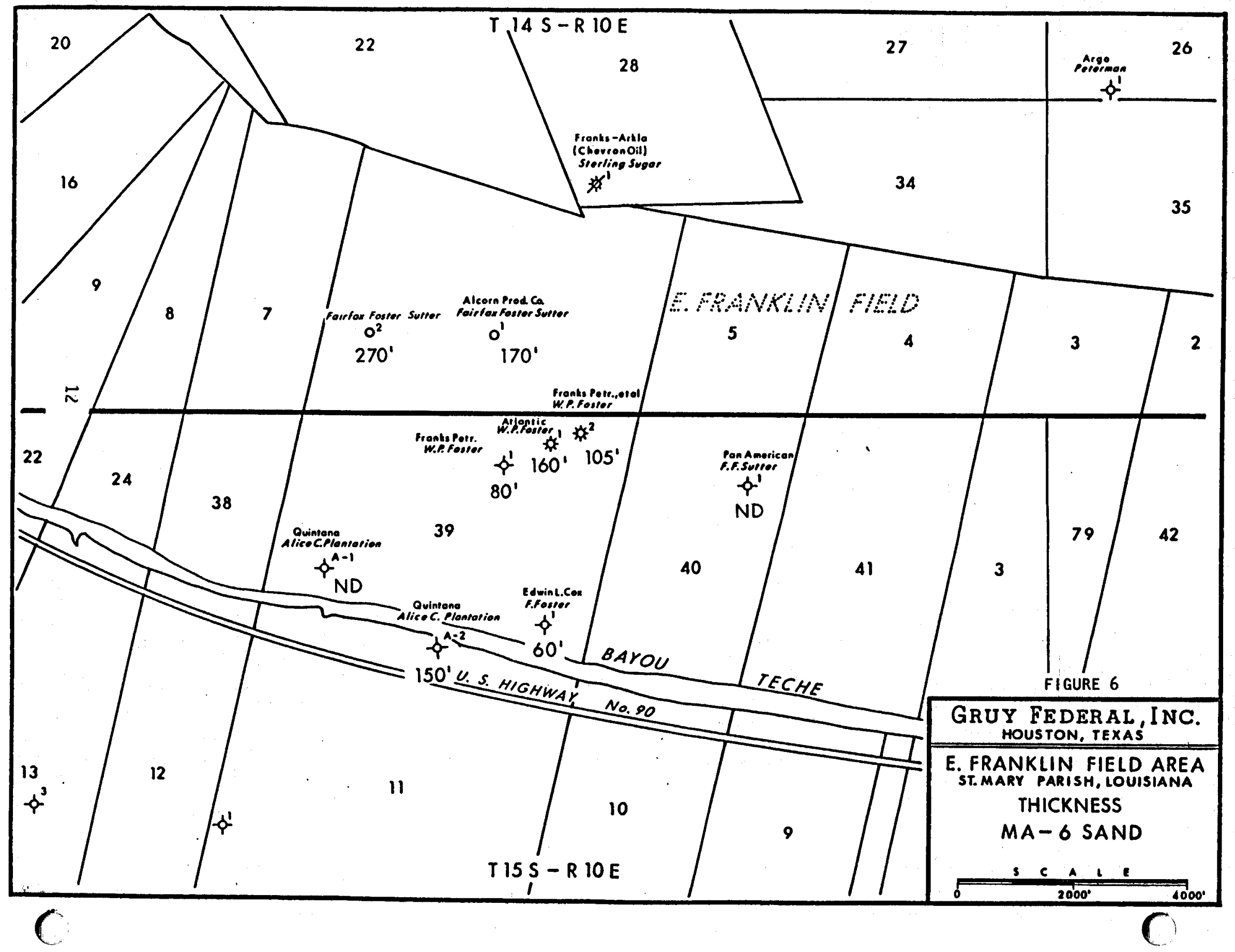




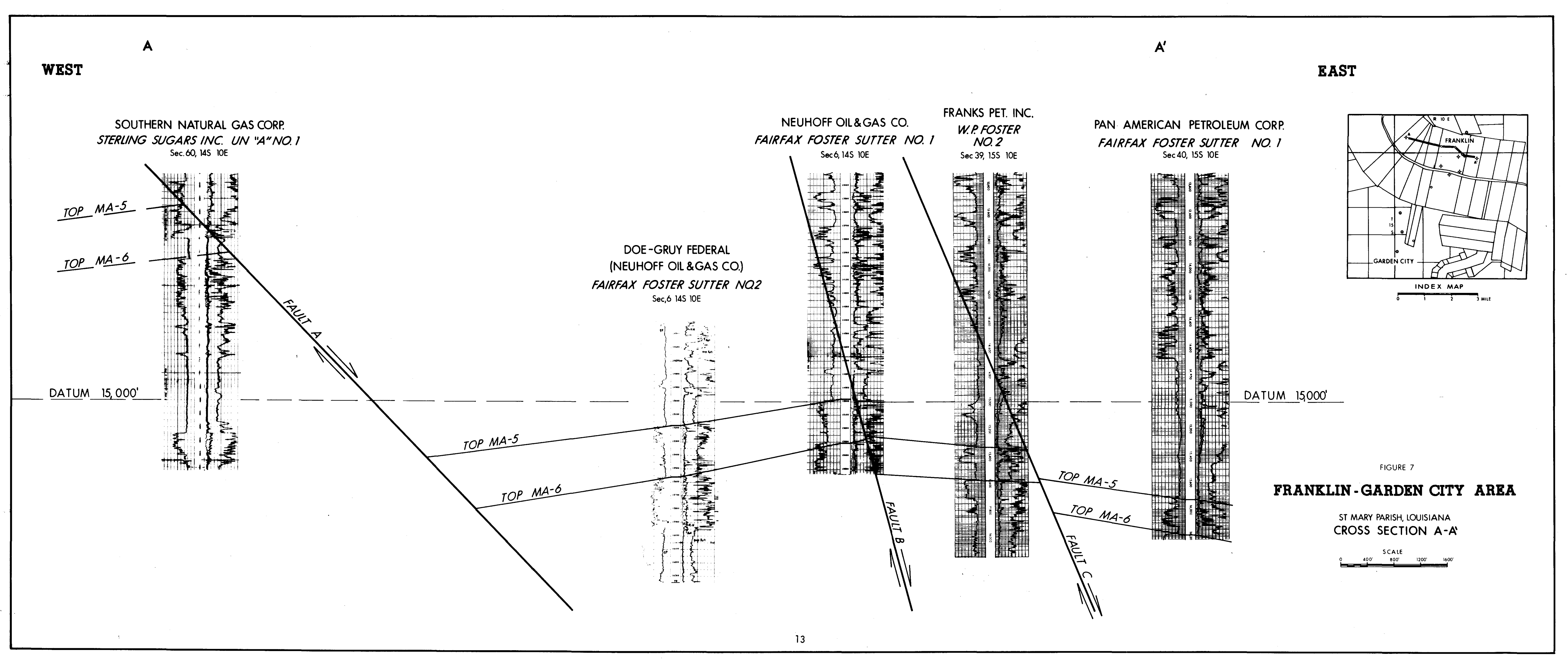




\subsection{Open Hole Log Analyses - Test Well}

Analysis of available log data was conducted in an effort to determine:

1. effective reservoir porosity

2. net effective reservoir thickness

3. a reasonable estimate of the reservoir permeability

4. the salinity of the reservoir fluid.

The final logging run was made prior to takeover, and the decision was made to proceed with the liner-setting operation rather than attempt to secure additional logging data. The log data consisted of a Schlumberger Cyber ${ }^{m}$ log which contained the following:
1. spontaneous potential
2. gamma ray
3. compensated formation density
4. compensated neutron porosity
5. induction - SFL
6. computed apparent water resistivity.

A discussion of the methodology used to determine the desired reservoir parameters follows.

\subsubsection{Porosity}

Porosity values through the test zone were determined by cross plotting the formation density with the neutron porosity data. The equation used to relate formation density to density porosity is:

$$
\phi_{D}=\frac{\rho_{m a}-\rho_{b}}{\rho_{m a}-\rho_{f}}-V_{s h}\left(\frac{\rho_{m a}-\rho_{s h}}{\rho_{m a}-\rho_{f}}\right) \text {, }
$$

$$
\text { where } \quad \begin{aligned}
\rho_{\mathrm{ma}} & =\text { matrix density }(\mathrm{gm} / \mathrm{cc}), \\
& \rho_{\mathrm{b}}=\text { bulk density }(\mathrm{gm} / \mathrm{cc}), \\
\rho_{\mathrm{f}} & =\text { fluid density }(\mathrm{gm} / \mathrm{cc}), \\
& \rho_{\text {sh }}=\text { shale density }(\mathrm{gm} / \mathrm{cc}), \\
\text { and } \quad V_{\text {sh }} & =\text { shale volume (decimal percentage). }
\end{aligned}
$$

The density data have been machine-processed to yield computed density porosities. After the parameters used in this procedure were reviewed and found satisfactory for the reservoir lithology, the density porosity data were sampled on 2-foot intervals. This resulted in a mean density porosity of 18.06 percent (standard deviation 2.08 percent). 
The compensated neutron porosity test had been calibrated for a sandstone lithology and did not require any matrix correction. Analyses of 2-foot samples through the $\mathrm{GeO}^{2}$ test zone yielded a mean neutron porosity of 20.48 percent (standard deviation 2.31 percent). The slightly greater neutron porosity is the result of shale content which, because of the relatively high connate water present, gives a neutron response much the same as fluid-filled porosity. The equation used to relate shale content to natural gamma activity is:

$$
V_{\text {sh }}=0.083\left(2.0^{3.7 I} \mathrm{gr}-1.0\right) \text {, }
$$

where $V_{\text {sh }}=$ shale volume (decimal fraction)

and $I_{g r}=$ gamma ray index (dimensionless);

$$
I_{g r}=\frac{G R_{l o g}-G R_{\text {clean sand }}}{G R_{\text {sh }}-G R_{\text {clean sand }}} \text {, }
$$

where $\mathrm{GR}_{\log } \quad$ = gamma reading of formation of interest,

$\mathrm{GR}_{\text {clean sand }}$ = gamma reading of a "clean" shale-free sand (API units), and $G R_{\text {shale }}$ = gamma reading of shale section (API units).

The test interval was indicated to be approximately 7.5 percent shale (standard deviation 0.6 percent).

Effective reservoir porosities through the test zone were obtained by the following equation:

$$
\phi_{E}=\left(\frac{\phi_{D}^{2}+\dot{\phi}_{N}^{2}}{2}\right)^{\frac{2}{2}} \text {, }
$$

where

$$
\phi_{E} \quad=\text { effective porosity, }
$$

and

$$
\begin{aligned}
& \phi_{D}=\text { density porosity, } \\
& \phi_{N}=\text { neutron porosity. }
\end{aligned}
$$

The mean effective reservoir porosity was indicated to be 19.3 percent (standard deviation 1.71 percent). The low standard deviation indicates a uniform clean sand interval. 


\subsubsection{Net Thickness}

The net thickness of the test zone was determined to be the sum of the perforated intervals $(58 \mathrm{ft})$. Selection of perforations was based on the response of shallow resistivity and formation-density measuring devices. These logging tools provide excellent thin-bed resolution and are usually able to differentiate sand/shale laminae which may not be apparent on a gamma-ray response.

\subsubsection{Reservoir Permeability}

A log-calculated permeability value was required early in the well program in order to estimate the well's deliverability and to design appropriate wellhead, testing, and disposal facilities.

Both Schlumberger and Dresser Atlas present empirical equations for estimating formation permeability, but unfortunately they are based upon core analysis data in which two immiscible fluids are present in the pores. Their application, therefore, requires a prior knowledge of the irreducible water saturation. The equations are quite similar, differing primarily in constants and units. Estimates made using both equations were nearly identical.

The equations are as follows:

A. Schl umberger

$$
k=\left(\frac{100_{\phi_{E}}{ }^{2.25}}{S w_{i r r}}\right)^{2},
$$

$$
\text { where } \begin{aligned}
k & =\text { permeability }(\mathrm{md}), \\
\phi_{E} & =\text { effective porosity (decimal), } \\
\text { and } S W_{i r r} & =\text { irreducible water saturation (decimal); }
\end{aligned}
$$

B. Dresser Atlas .

$$
k=\frac{0.136 \phi_{E}^{4.4}}{S w_{i r r}{ }^{2}}
$$

where $k=$ permeability $(m d)$,

$\phi_{E} \quad=$ effective porosity (percent),

and $\mathrm{SW}_{\mathrm{irr}}=$ irreducible water saturation (percent). 
Assuming that Swirr is 100 percent (which is known to be too high), the permeabilities calculated for the mean effective porosity (19.3 percent) from Eqs. 4 and 5 are 6 md and $6.2 \mathrm{md}$, respectively. Figure 8 graphically shows the relationship between permeability and Swirr for the mean reservoir porosity. Since cores were not available for capillary pressure analyses, accurate determination of the irreducible water saturation was impossibie. The test program was designed on the basis of an anticipated permeability between 6 and 28 md (corresponding to an Swirr range of 100 to 50 percent). Analys is of reservoir data indicates an effective permeability of approximately $15 \mathrm{md}$, which corresponds to an Swirr value of 63 percent.

\subsubsection{Salinity}

In order to estimate gas solubility and potential scaling and corrosion problems, a knowledge of the formation water salinity was required. This was calculated by two methods.

\subsubsection{R $R_{\text {wa }}$ Method}

The salinity (expressed in equivalent parts per million of $\mathrm{NaCl}$ ) was determined as a function of temperature and apparent water resistivity by the following procedure.

$$
\mathrm{NaCl}(\mathrm{ppm})=\left(\frac{3647.5}{\mathrm{R}_{\mathrm{w}}\left(75^{\circ}\right)-0.0123}\right)^{1 / 0.955}
$$

where $\quad R_{W}\left(75^{\circ}\right)=$ resistivity of the water at $75^{\circ} \mathrm{F}\left(\mathrm{ohm}-\mathrm{m}^{2} / \mathrm{m}\right)$

and

$$
R_{W\left(75^{\circ}\right)}=R_{W(\text { res })}\left(\frac{T^{T}(\text { res })+7.0^{\circ} \mathrm{F}}{82.0^{\circ} \mathrm{F}}\right),
$$

where $R_{W}($ res $)=$ apparent resistivity of the reservoir water $\left(0 \mathrm{hm}-\mathrm{m}^{2} / \mathrm{m}\right)$ and Tres = reservoir temperature $\left({ }^{\circ} \mathrm{F}\right)$

The apparent resistivity of the formation water, $R_{w}(r e s)$, was obtained from a derivation of the familiar Humble formation factor equation,

$$
R_{W(\text { res })}=\frac{R_{T} \phi_{E}^{2.15}}{0.62}
$$


FIGURE 8

FAIRFAX - FOSTER SUTTER NO. 2

PERMEABILITY VS. SWirr

FOR POROSITY OF

$19.3 \%$

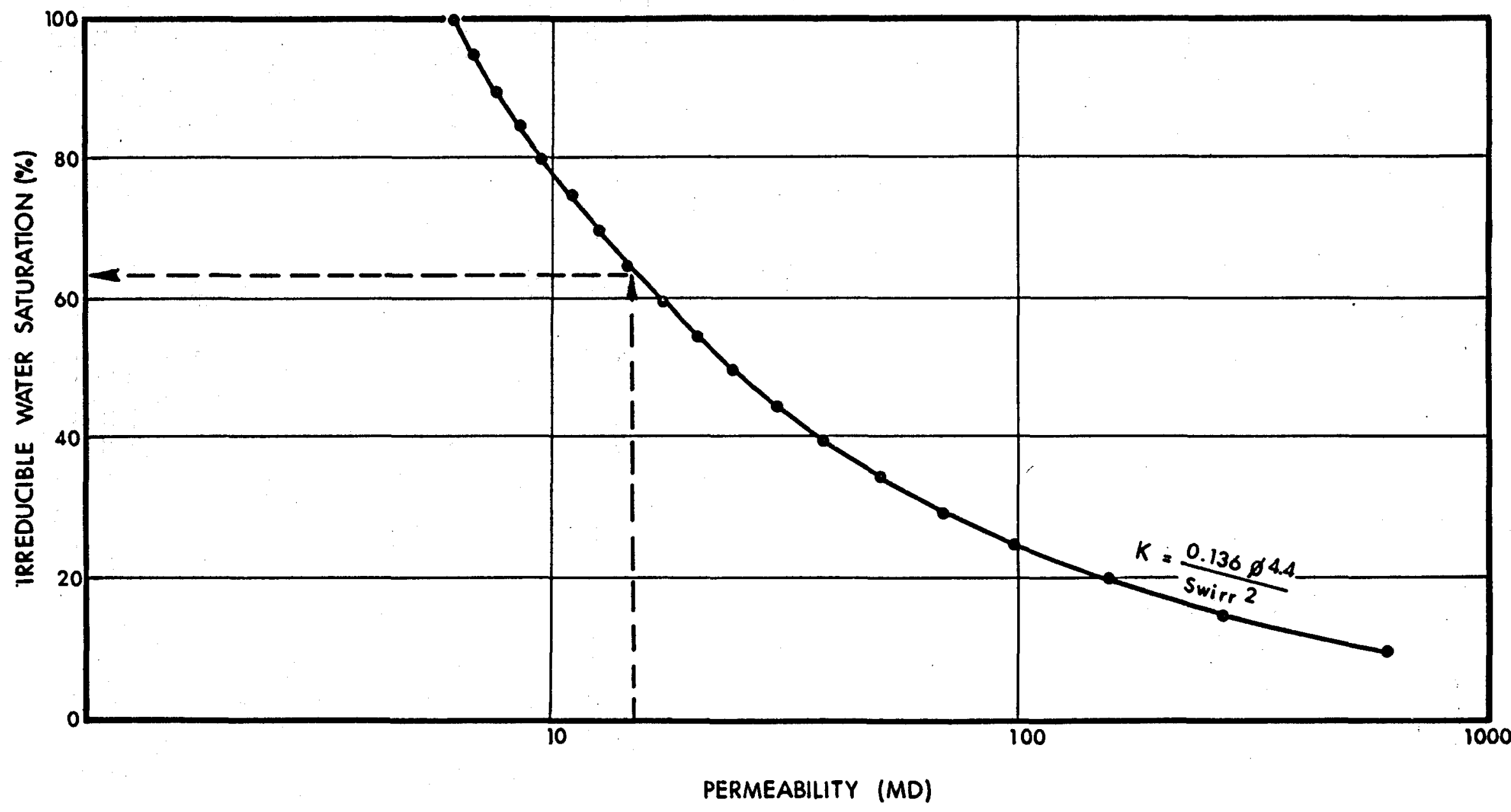


where $\quad R_{T}=$ resistivity of the undisturbed formation (ohm- $\mathrm{m}^{2} / \mathrm{m}$ ) and $\phi_{E}=$ effective porosity (decimal).

To arrive at Eq. 8, 100 percent water saturation was assumed, making the value of the saturation exponent insignificant.

The mean $R_{W(\text { res) }}$ calculated was $0.025 \mathrm{ohm}-\mathrm{m}^{2} / \mathrm{m}$ (standard deviation 0.005 ohm- $\mathrm{m}^{2} / \mathrm{m}$ ) as determined by the analyses of 2-foot samples through the test zone. Wireline data indicated a reservoir temperature of approximately $270^{\circ} \mathrm{F}$. Using these parameters, the total salinity was calculated to be equivalent to $84,216 \mathrm{ppm}(\mathrm{mg} / 1) \mathrm{NaCl}$.

\subsubsection{SP-Derived RW}

Solving for formation fluid resistivity from the SP (spontaneous potential) and then solving for equivalent $\mathrm{NaCl}$ salinity yielded results nearly identical to the $R_{\text {wa }}$ method. The biased mean value of the SP-calculated $\mathrm{RW}^{\prime} \mathrm{s}$ was $0.0231 \mathrm{ohm}-\mathrm{m}^{2} / \mathrm{m}(92,846 \mathrm{ppm} \mathrm{NaCl})$. The equations used to determine the resistivity of the formation fluids are:

$$
R_{w}=\frac{R_{w e}+0.131\left[10^{1 /\left\{\log \left(T_{f} / 19.9\right)-2.0\right\}}\right]}{-0.5 R_{w e}+10^{\left[0.0426 / \log \left(T_{f} / 50.8\right)\right]}}
$$

and

$$
R_{w e}=R_{m f}\left(10^{\left[S S P /\left(60+0.133 T_{f}\right)\right]}\right) \text {, }
$$

where $R_{m f}=$ resistivity of mud filtrate at formation temperature (ohm- $m^{2} / m$ ) and SSP = static spontaneous potential (millivolts).

The discrepancy between log-calculated salinity obtained by two independent methods and the chemical analysis of the produced water may be due in part to bound fluids of lower sal inity. Such a "dual-water" system is not uncommon in the Gulf Coast Miocene, but it is usually associated with somewhat shalier sands. It is possible that the Hilchie algorithm (Eq. 2) relating shale content to gamma-ray index for tertiary sediments is not applicable to this environment. More sophisticated computer modeling techniques (such as Saraband" or Epilog"') may help to resolve these discrepancies between observed and calculated salinities. 


\subsection{Open-Hole Log Analysis - Disposal Well.}

The available log data were analyzed to identify the zones of highest injectivity potential. Log data consisted of an induction-sonic log with an SP recording. The minimum acceptable disposal depth ( 3400 feet) had been specified earlier by the Louisiana Department of Conservation. Based on a correlation with offset wells, the decision was made to drill the disposal well to $4,000+$ feet, then $\log$ and assess the injectivity potential at that depth. The well penetrated three qualifying sand members ranging in thickness from 80 to 120 feet. The observed porosities ranged from 29.4 to 37.1 percent, the mean being 33.7 percent (standard deviation 1.82 percent).

The equation used to transform sonic interval transit time to porosity is:

$$
\phi_{s}=\frac{\Delta t-\Delta t_{m a}}{\Delta t_{f}-\Delta t_{m a}}\left(\frac{100}{\Delta t_{s h}}\right)-v_{s h}\left(\frac{\Delta t_{s h}-\Delta t_{m a}}{\Delta t_{f}-\Delta t_{m a}}\right),
$$

where $\phi_{S}=$ sonic porosity,

$$
\Delta t=\log \Delta t(\mu \mathrm{sec} / \mathrm{ft}) \text {, }
$$

$\Delta t_{\text {ma }}=$ matrix travel time $(58.8 \mu \mathrm{sec} / \mathrm{ft})$,

$\Delta t_{f}=$ fluid travel time $(190 \mu \mathrm{sec} / \mathrm{ft})$,

$\Delta t_{\text {sh }}=$ shale travel time $(140 \mu \mathrm{sec} / \mathrm{ft})$,

and $\quad V_{\text {sh }}=$ shale content (estimated to be 0.15 ).

\subsection{Cased-Hole Log Analysis}

Cased hole logs consisted of:

1. Gamma ray/neutron/collar log

2. Cement bond log

3. Casing inspection log (test well only).

These logs were run to determine the integrity of the cementing, to establish an open-hole/casing-collar correlation, and to verify that the casing wall thickness was satisfactory. An explanation of the various qualitative interpretation techniques used to analyze these logs is beyond the scope of this report. 
6.0 DRILLSITE AND SUPPORT FACILITIES

6.0.1 Site Layout

The drillsite layout shown in Fig. 9 acçommodated conventional drilling equipment used for completion of the $\mathrm{GeO}^{2}$ well and the drilling of the disposal well. The living quarters and office facilities were located on the turnaround area at the site, convenient to the test well, disposal well, and surface production facilities.

Waste oil and grease spillage was trapped and drained into a ditch around the rig for recovery and disposal to prevent contamination of the area. This is a standard practice and is required by State and Federal environmental agencies.

\subsubsection{Living Quarters}

A three-bedroon, air-conditioned house trailer provided quarters for drilling consultants and Gruy representatives. Motel accommodations were available in nearby Franklin, Louisiana.

\subsubsection{Water Supply}

Potable water, hauled to the site and stored in a sanitary tank, was used as drinking water, as engine coolant, and for preparing drilling mud and cement.

\subsubsection{Utilities}

No telephone lines were available at the test site. The nearest rellable phone service was in Franklin, La., some four miles from the test well. The radiotelephone provided at the well site carried heavy traffic most of each day.

During completion operations, the rig had 110-volt electrical power adequate to meet anticipated requirements. During the test period, rental generators were used to provide lighting.

\subsection{TEST WELL DESIGN}

\subsubsection{Initial and Anticipated Well Completion Status}

Figure 10 shows the status of the hole at the time of takeover, the anticipated design arrangements, the actual design that evolved, and the status of the well after final plugging and abandonment.

\subsubsection{Liner and Tubing Installation}

Table 1 summarizes the design for the tubular goods installed in the well by Neuhoff prior to the transfer of operations to Gruy. The Table also shows the liner and tubing design as well as cementing specifications for the equipment installed by Gruy during completion operations. The opera- 


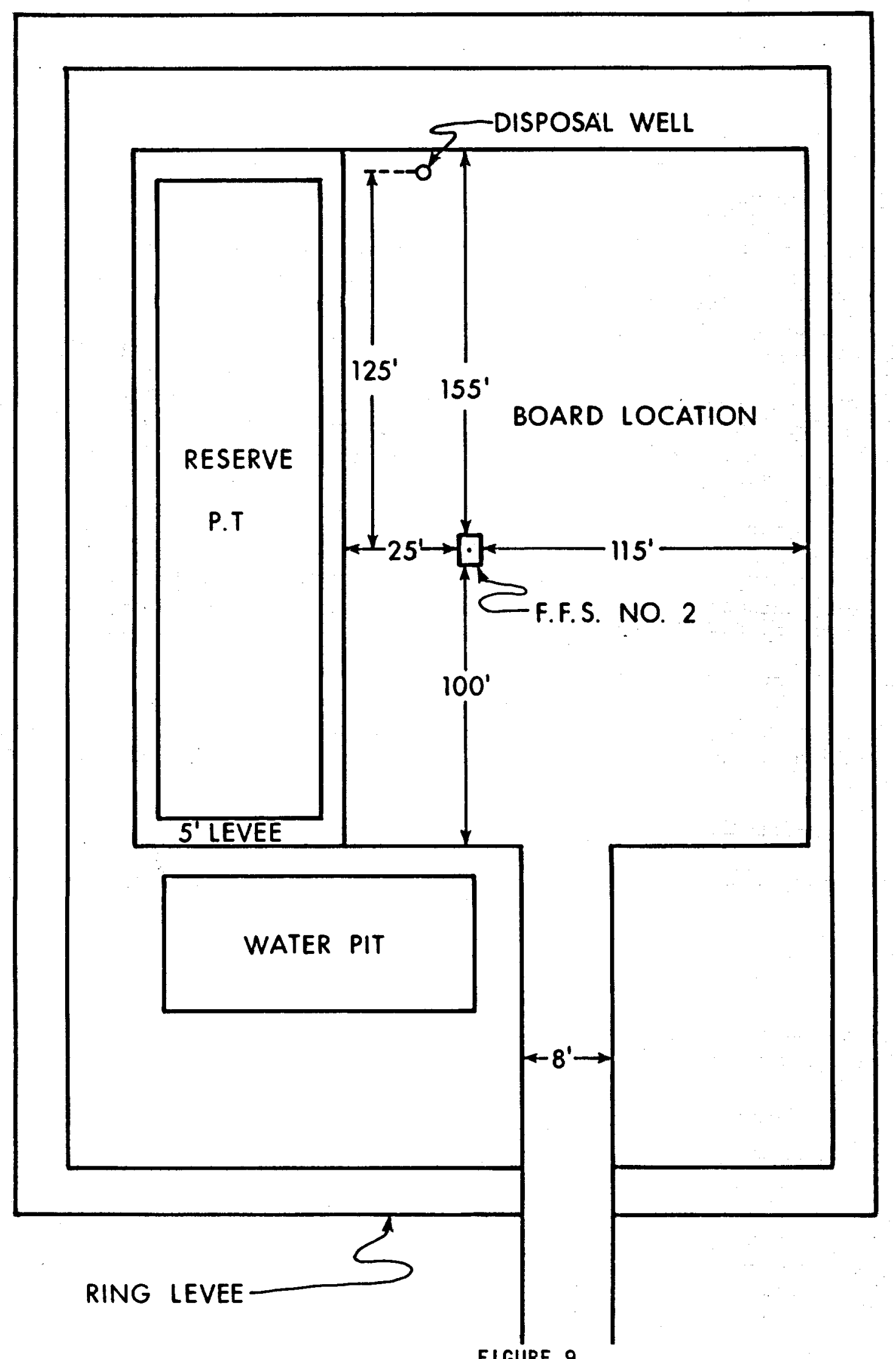

FIGURE 9

FAIRFAX FOSTER SUTTER NO. 2

SCHEMATIC LOCATION PLAT 


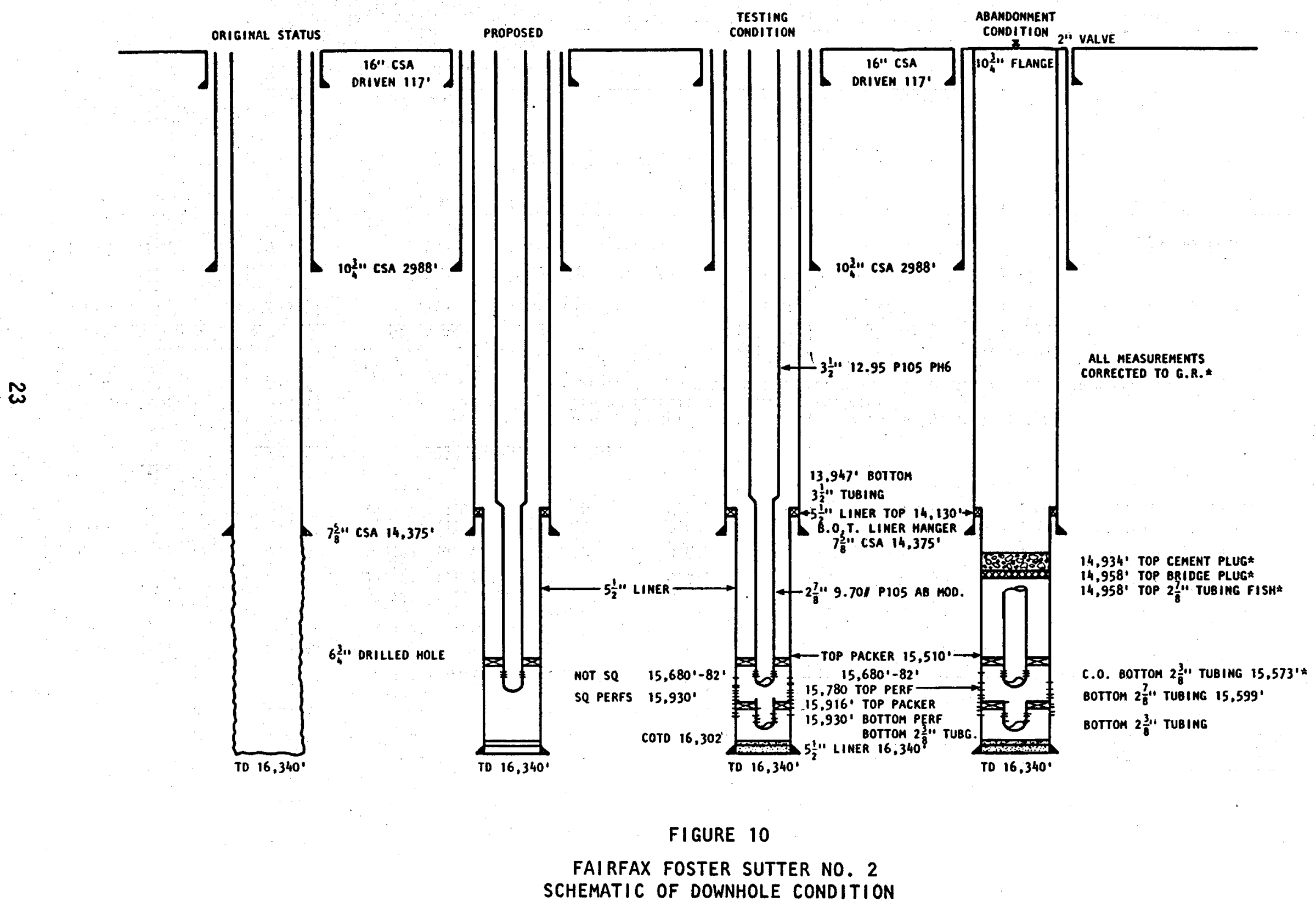


TABLE 1

TUBULAR AND CEMENTING DESIGN SPECIFICATIONS FAIRFAX FOSTER SUTTER NO. 2

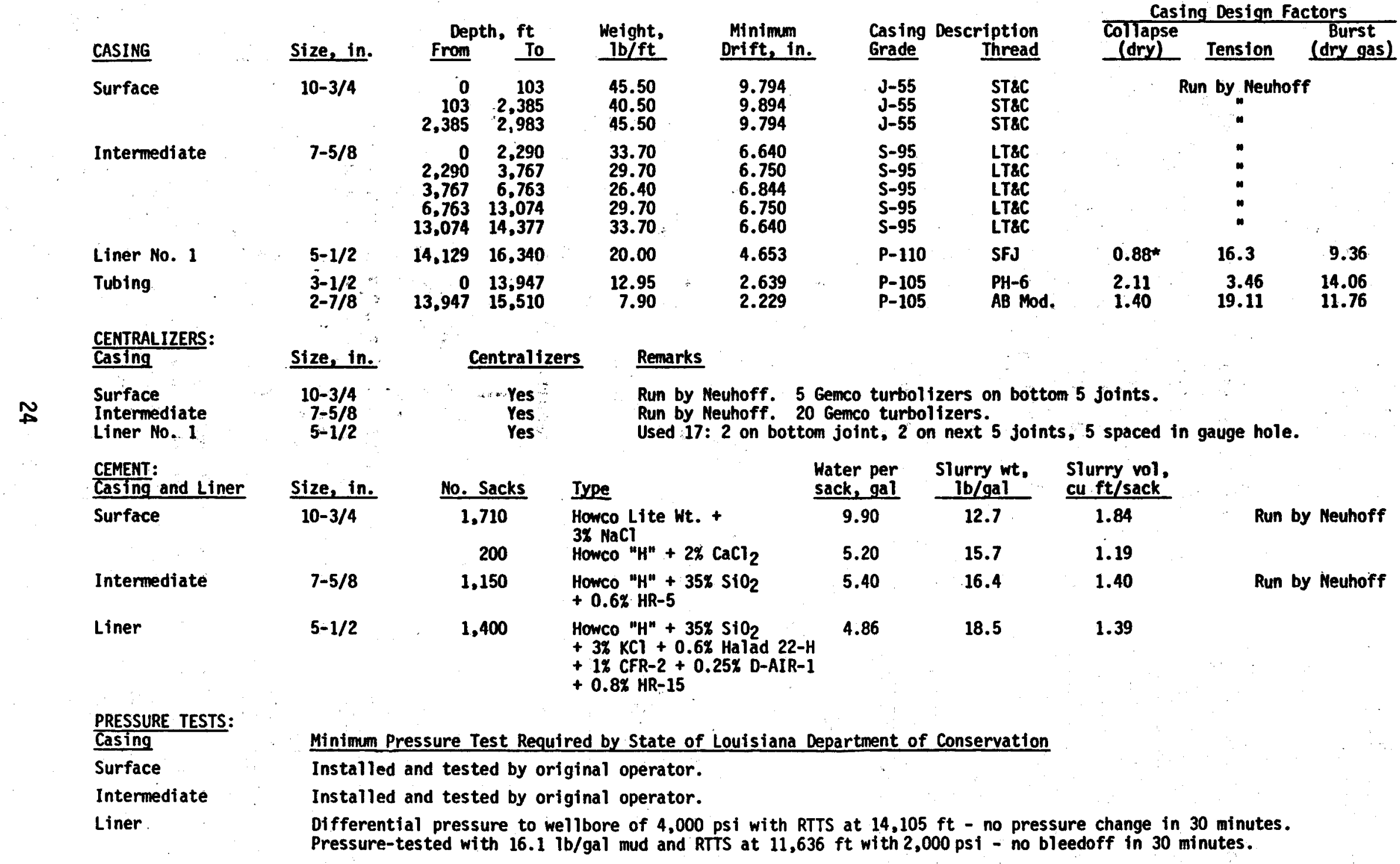

\#Safety factor collapse shown with hole void of fluid. Safety factor becomes 1.0 with minimum of $1,600 \mathrm{ft}$ of formation water in hole. 
tional procedures for setting the liner and the tubing are covered in Section 6.3.1.

\subsubsection{Wellhead Design}

Figure 11 is a sketch of the wellhead and christmas tree acquired for this well. The tree has a rated working pressure of 10,000 psi and rated test pressure of 15,000 psi. All gate valves in the vertical run of the tree are manufactured from T-24 steel with packing and seals adequate for $300^{\circ} \mathrm{F}$ service. The tree consists of two 3-1/16 inch diameter master gate valves and a 3-1/16 inch swab valve. Between the master gate valve and the swab valve is a double flow $T$ assembly that also houses choke bodies in either wing. One wing contains a positive choke and the other an adjustable choke. Each wing included a high-low surface safety valve and a conventional regular ported $10,000-16$ wing valve. The dual flow wings were designed to balance bending moments near the top of the tree during maximum flow conditions.

As a result of the experiences during operations discussed in Section 6.3, some minor modifications will be made in the arrangement of the tree for subsequent operations.

\subsubsection{Logging Program}

\subsubsection{Open Hole Logs}

The suite of logs obtained by Neuhoff in the open-hole section of this well included an ISF-Sonic log that was adequate for evaluation purposes. Therefore no additional logs were taken in the open hole.

\subsubsection{Cased Hole Logs}

After the 5-1/2 inch liner was run and cemented, gamma-ray/neutron, cement bond, and collar locator logs were run to serve as a reference for perforating and to meet State regulatory requirements that a gamma-ray/ neutron $\log$ be run through all potential $\mathrm{Geo}^{2}$ sands.

\subsection{DRILLING OPERATIONS: TEST WELL}

\subsubsection{Blowout Preventers}

The blowout preventers and accumulator tank were inspected and found to conform to the specifications set out in the Gruy Standard Test Procedure and Maintenance Program dated November, 1978, prepared by W. C. Goins, a recognized authority on well control.

\subsubsection{Drilling Fluids}

At the time of Gruy's takeover of the well, the drilling mud in the well was $16.1 \mathrm{lb} / \mathrm{gal}$ lignosulfonate mud with a viscosity of $48 \mathrm{sec}$ API, a pH of 11.0 , and a fluid loss of $3.2 \mathrm{ml}$. The supplier of drilling mud and mud engineering services at commencement of operations was a small independent 
FIGURE II

FAIRFAX FOSTER SUTTER NO. 2
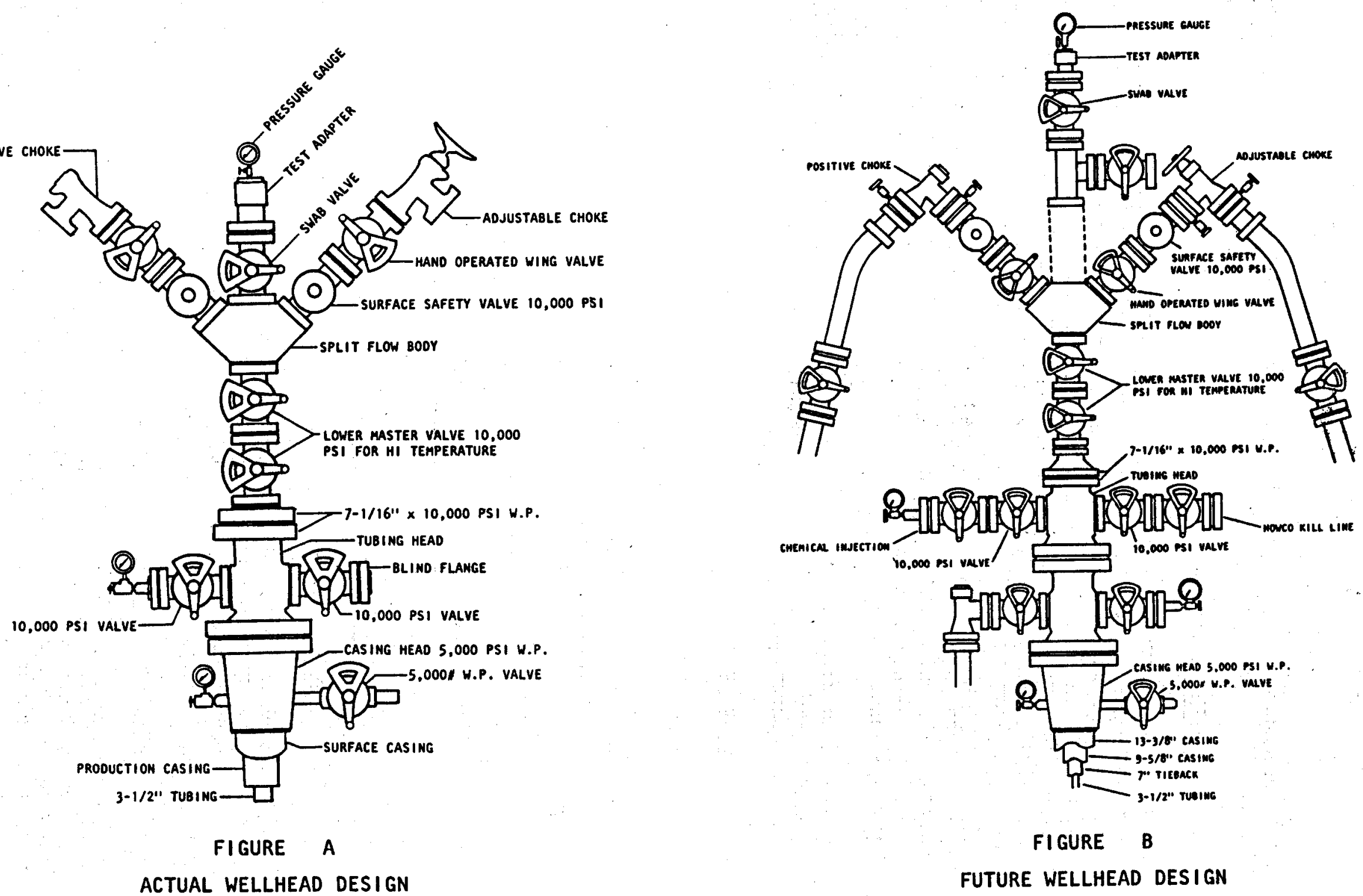
company. As will be discussed in the section on operations, substantial difficulties were experienced with the mud system, necessitating a change to a larger supplier for mud who could provide greater depth in engineering services.

\section{$6.3 \quad$ COMPLETION OPERATIONS \\ 6.3.1 Open Hole Operations}

While awaiting approval from DOE to assume operations on the No. 2 Sutter well, the operator circulated the mud for 24 hours with the drill bit inside the protection casing at a depth of 14,289 feet.

When operations were assumed at 2:45 p.m. on March 9, 1979, a 5-1/2 inch OD casing liner was ordered to the well while Gruy's drilling engineers directed the driller to lower the drill pipe into the open hole preparatory to conditioning the hole to run the liner. Drill pipe was lowered to 15,160 feet, where an obstruction was encountered and reamed. The first solid bridge was encountered at 15,863 feet. At this depth, the hole yielded large quantities of shale over the high-speed shale shaker for several hours. After the shale condition was cleaned up, the drill pipe was lowered to 16,297 feet by rotating the pipe and circulating fluid. It was necessary to ream and wash the hole from this depth to the original total depth of 16,340 feet (pipe measurements; 16,348 feet, electric. $10 \mathrm{~g}$ measurements). The hole was circulated clean for a period of $8-1 / 2$ hours.

Upon making a precautionary short trip into the 7-5/8 inch protection casing, no drag was observed. The drilling mud was circulated from a depth of 14,168 feet for 8-1/2 hours and conditioned to the desired physical properties.

After the mud was conditioned, drill pipe was run to 16,340 feet by circulating each joint down. During circulating and cleaning the hole, shale heaved severely for 2 hours and then cleaned up for 3 hours of circulation with no heaving shale. Upon starting to pull pipe for a short trip into the protection casing, the drill pipe became stuck with the bit at 16,307 feet. Mud circulation was normal with full circulation returns at the surface, but the rig could not rotate the pipe string or move it up or down the hole. Circulation was maintained while oil-base mud was delivered to the location. The oil-base mud was displaced to the bottom of the drill pipe and into the open hole around the outside of the stuck pipe. Circulation was essentially stopped periodically while the rig attempted to pull the pipe free, continuing to pump the oil-base mud up the annulus at a rate of about $1 / 2$ barrel every 15 minutes. After one-half hour, the pipe came free and was pulled up into the protection casing with no drag. The bit was then rerun to $16 ; 340$ feet without encountering any obstructions and then pulled out of the hole with no detectable drag.

The evidence outlined above indicates that the drill pipe was differentially stuck opposite the upper portion of the $\mathrm{Geo}^{2}$ sand. Measures to prevent recurrence of differential sticking of drill pipe in open hole include 
the use of spiral drill collars below protection casing when hole conditions require heavy drilling muds. This has been established as a policy for all future Gruy operations.

\subsubsection{Casing Liner}

Prior to pulling drill pipe in preparation for running the liner, a casing crew made all possible preliminary rig-up of tools and equipment in order to minimize exposure of the open hole after it had been conditioned. At the same time, the centralizers, guide shoe, and float collar were installed on the pipe while it was on the rack.

The casing designed to run in the hole was 5-1/2 inch $00,201 \mathrm{~b} / \mathrm{ft}, \mathrm{P}-110$, super flush joint (SFJ) designed for safety as shown in Table 1.

Halliburton 0il Well Cementing Company designed the specifications for cementing the casing liner based on samples of the water used at the site. The cement volume requirement was calculated and mixed to the following specifications: 1400 sacks of Class $\mathrm{H}$ cement plus 35 percent silica flour plus 3.0 percent potassium chloride, 0.006 percent Halad 22, 1 percent CFR-2, 0.0025 percent D-AIR-1, 0.008 percent HR-5, and 5.56 gallons of water per sack. The slurry density was $18.5 \mathrm{lb} / \mathrm{gal}$. The additives used in the slurry served the following purposes:

\begin{tabular}{|c|c|}
\hline Silica flour & $\begin{array}{l}\text { - to provide additional cement strength } \\
\text { at bottomhole temperature }\end{array}$ \\
\hline $\mathrm{KCl}$ and $\mathrm{Hal}$ ad & $\begin{array}{l}\text { - inhibition of the cement filtrate water } \\
\text { to avoid problems with bentonitic shales } \\
\text { present in the hole }\end{array}$ \\
\hline CFR-2 & $\begin{array}{l}\text { - a dispersant to reduce the slurry } \\
\text { critical flow rate. }\end{array}$ \\
\hline D-AIR-1 & - an antifoam agent \\
\hline$H R-5$ & $\begin{array}{l}\text { - a retarder to increase cement setting } \\
\text { time to that required to mix and pump } \\
\text { cement into place. }\end{array}$ \\
\hline
\end{tabular}

The casing crew had completed rigging up its tools when all drill pipe and collars were out of the hole. Fifty-four joints of 5-1/2 inch 00,20 1b/ft, P-110, SFJ Hydril casing equipped as shown on Fig. 6 was run on the drill pipe at a rate of $30 \mathrm{ft} / \mathrm{min}$, filling each nine stands, to a total depth of 16,340 feet. The top of the liner was at 14,140 feet. The liner was hung off inside the 7-5/8 inch casing on a Brown 0il Tool type CMC liner hanger with a polished bore receptacle and tieback sleeve. When the liner had been landed, the cementing manifold was attached to the drill pipe at the surface and cement was pumped into the hole. Thirty barrels of SAM-5 spacer, bumper plug, and cement were displaced down the drill pipe with drilling mud. The pump pressure had reached 2125 psi when the plug sealed off in the float collar. Pressure was bled off to $1200 \mathrm{psi}$ with no 
back flow into the weTl bore. Full mud returns were maintained throughout the displacement of the cement.

Upon completing the cement placement operation, 30 minutes were required to pull the stinger seals from the polished bore receptacle. After the seals were removed, attempts to reverse circulate with a surface pressure of 2500 psi were unsuccessful. No attempt to reverse out at a higher pressure was made because of the possibility of disturbing the cement behind the liner. Ten stands of drill pipe were pulled and reverse circulation was established at a rate of $2 \mathrm{bbl} / \mathrm{min}$ with $250 \mathrm{psi}$ surface pump pressure. The pump pressure increased to $750 \mathrm{psi}$ and the pump rate decreased to $0.5 \mathrm{bbl} / \mathrm{min}$, suggesting that cement was setting up in the drill pipe. The hole was circulated clear of cement returns. The crew continued to pull drill pipe with the hole swabbing. It was necessary to fill the hole each five stands. At this point it had become evident that the cement was setting prematurely and that cement had accumulated at least around the top of the liner setting tool. After the second 10 stands of drill pipe were pulled, the pipe pulled dry without swabbing.

\subsubsection{Cleanout of Cement from Production Casing}

After liner running tools were laid down, it was noted that two brass PBR seals had been left in the hole. A drilling assembly was then made up consisting of a drilling bit, bit sub, eight 4-3/4 inch OD spiral drill collars, oil jars, and heavy weight drill pipe, which was run in the hole. Circulation was broken at 1836 feet and at 7336 feet. Cement was encountered at 9208 feet. Soft to firm cement was drilled to 11,550 feet when the bit stopped making hole. The mud was severely contaminated with cement and was also dehydrated, very viscous, "and ropy in character. Similar to old-fashioned syrup candy, the mud would string out into pencil-thin streams for as much as 2 feet before separating.

While pulling out of the hole to change bits it was necessary to up-ream through the interval from 10,890 to 9989 feet.: Upon recovering the bottomhole assembly it was found that the top five threads on the bit were stripped and the bottom threads damaged; the bit was left in the hole.

A trip was made with a 7-5/8 inch casing scraper and a 6-5/8 inch rock bit, requiring 8 hours to ream cement and dehydrated mud from 9290 to 10,102 feet, where the fish was encountered. The fish did not move with 10,000 lb of weight, nor would it take torque when the bit was rotated. The bit and scraper were pulled from the hole.

A leaded bit sub would get over the pin end of the fish, but would not hold it.

After working on the fish with up to. $5000 \mathrm{lb}$ while conditioning the mud, the bit moved down the hole to 11,559 feet. The leaded bit sub failed to catch the fish; however, there were indications that the pin had been inside the leaded sub. Another bit sub and sçraper failed to catch the fish but showed a slight indication of damage on the bottom of the box sub. A pipe weight of $20,000 \mathrm{lb}$ was set on the fish. The pump pressure 
increased and the drill pipe was started out of the hole; it pulled wet for the first 42 stands before the fish apparently fell off the pipe. A shortcatch overshot with 3-inch grapples was run and applied to the fish several times with $20,000 \mathrm{lb}$ with no recovery. The same hookup with $2-3 / 4$ inch grapples failed to catch the fish, but showed definite signs of having been over it. Attempts to run an impression block on a wireline failed to get deeper than 10,156 feet because of thick mud. The short-catch overshot with 2-5/8 inch grapples was run to the top of the fish and the mud conditioned prior to setting 50,000 $\mathrm{lb}$ of weight on the fish. The fish then engaged in the overshot and was recovered when the pipe was pulled.

In an effort to resume cleaning the cement out of the 7-5/8 inch casing, a $6-5 / 8$ inch cement mill was run. After milling cement from 11,623 to 11,674 feet, the penetration rate decreased to $8 \mathrm{ft} / \mathrm{hr}$ and fine metal cuttings appeared on the shaker. Milling was stopped and the hole was conditioned until clean. A trip was made to change to a 6-3/4 inch bit to continue drilling cement to the top of the liner. Prior to drilling ahead, the casing was pressurized to 1000 psi for 15 minutes without pressure loss, indicating that the casing was intact. Drilling cement was resumed to 12,454 feet, and a short trip was made to check for drag in the area where cement had been drilled. Firm cement was then drilled to 14,137 feet (top of liner), with periodic precautionary short trips to check for drag. The drilling mud was conditioned and a trip made to change to a 4-1/2 inch bit to clean out inside the 5-1/2 inch liner. Cement was drilled in the top 3 feet of the liner, then the hole was conditioned to 16,383 feet (top of float collar) before pulling out of the hole.

\subsubsection{Cased Hole Logs}

Schlumberger was rigged up and a cement bond log, variable density, gamma $\mathrm{ray} /$ neutron $\log$ and collar locator were run from 16,288 to 13,500 feet (top of the 5-1/2 inch liner at 14,130 feet by GR measurements and 14,129 feet by drill pipe measurements). The gamma-ray/neutron $\log$ was run to the surface to comply with requirements of the Department of Conservation.

A McCullough casing inspection $\log$ was run from 14,130 feet (top of liner) to the surface to check the integrity of the 7-5/8 inch casing. The $\log$ indicated 92 percent of original wall thickness from 11,664 to 11,620 feet (milled section of casing), while the rest of the string was of normal thickness or more.

\subsubsection{Squeeze Operations}

The top of the 5-1/2 inch liner was tested by running a Halliburton RTTS tool to 14,105 feet. Drilling mud was displaced from the drill pipe with water so that a differential pressure of 4000 psi existed when the test tool was set. This pressure was held for 30 minutes without loss. The bypass on the tool was opened and the water displaced from the pipe with mud. The mud was then conditioned to $16.1 \mathrm{lb} / \mathrm{gal}$ and the RTTS tool pulled from the hole.

It was the opinion of Schlumberger and Gruy. engineers that the cement bond 
$\log$ indicated a need for block squeezing with cement below and above the objective $\mathrm{GeO}^{2}$ sand. The lower block squeeze was to be perforated with a casing gun after pulling the RTTS tool. Schlumberger was rigged up, but excessively thick, contaminated drilling mud prevented a 3-1/8 inch casing gun going below 14,163 feet.

A trip in the hole with a 4-1/2 inch bit and 5-1/2 inch casing scraper was made and a bridge of dehydrated mud was encountered at 14,687 feet. When picked up to commence washing the bridge, the bit was found to be plugged and had to be surged to establish circulation. The hole was then washed and reamed to 16,282 feet, breaking circulation after each stand in the hole. Mud was then conditioned for 5 hours and pulled out of the hole. The casing was then tested to 2,000 psi satisfactorily.

Schlumberger was rigged up and a 3-1/8 inch casing gun run in the hole. The casing was perforated from 15,930 to 15,932 feet (electric $10 \mathrm{~g}$ and gamma-ray measurements). An RTTS tool was run in the hole to the top of the liner and circulation broken. The RTTS tool started inside the liner and encountered 5000 to $15,000 \mathrm{lb}$ drag to 14,409 feet. An attempt to break circulation with 2200 psi was unsuccessful. Drill pipe was raised to 14,223 feet and circulation was obtained with 2000 psi pump pressure. The squeeze tool was lowered to 15,854 feet, breaking circulation each joint of drill pipe. After circulating and conditioning mud, the RTTS tool was set at 15,846 feet and the casing was tested to 1000 psi. The bypass was then opened to establish circulation with 1550 psi and a reverse-out pressure of $1600 \mathrm{psi}$ at $1.5 \mathrm{bbl} / \mathrm{min}$. The bypass ports were closed and the formation was broken down at $3500 \mathrm{psi}$ with a $2 \mathrm{bbl} / \mathrm{min}$ pump-in rate. Three hundred gallons of mud acid, followed by 100 sacks of Class $H$ cement with 35 percent silica flour, 0.75 percent DFR-2, and 0.8 percent HR-12, with density of $16.5 \mathrm{lb} / \mathrm{gal}$, followed by $10 \mathrm{bbl}$ water, were displaced to the bottom of the drill pipe. The RTTS bypass was closed and acid followed by cement was squeezed into the formation at $1 \mathrm{bbl} / \mathrm{min}$.

A maximum and final squeeze pressure of 3500 psi was obtained when 75 sacks of cement were squeezed out. The balance of the cement was reversed out. The RTTS tool was released and pulled up the hole to 15,543 feet, where the mud was circulated and conditioned.

Schlumberger rigged up a 1-3/8 inch through-tubing perforating gun with four shots per foot which was run to 13,866 feet-but failed to go deeper. The gun was pulled from the hole and the well circulated to condition mud and pulled out of the hole with the squeeze tool. A 3-3/8 inch casing perforating gun was run in the hole and the 5-1/2 inch casing perforated from 15,680 to 15,682 feet (IES measurements; 15,678 to 15,680 feet, gamma-ray measurements). A 5-1/2 inch RTTS tool was run to 15,545 feet, but could not break down the formation with 3500 psi and could not lower the RTTS tool. The RTTS tool was pulled and rerun to 15,545 feet, but still could not break down the formation. The bypass valve was opened and the mud in the drill pipe was displaced with fresh water to the equivalent of 4500 psi differential. The bypass was closed and the pressure differential bled off in 500-psi increments. When the pressure on the drill pipe decreased to 1300 psi, the well started to flow back into 
Halliburton truck tanks (two barrels recovered). The well was shut in at the surface with 2,000 psi for 20 minutes. Water was reversed out of the drill pipe with mud and an unsuccessful attempt was made to break down the perforations for squeeze with 7000-psi surface pressure. The pressure was released and the squeeze tool removed from the hole. Since the upper block-squeeze perforations could not be squeeze-cemented and would in fact flow, it was necessary to revise the original plans for perforating the objective Geo ${ }^{2}$ sand with a differential pressure to the well bore for the initial gun section and a balanced column for the remainder of the sand. It became necessary to perforate with a casing gun and with mud in the hole.

In preparing to complete the well, it was necessary to replace the 5000psi working pressure casinghead installed by the original operator with a $10 \times 10$-inch 10,000-psi working pressure head compatible with the Christmas tree for the well. This necessitated setting a storm packer at 3000 feet, removing the BOP stack, replacing the head, reinstalling the BOP stack, and removing the stom packer. The BOP stack was satisfactorily tested to 10,000 psi.

\subsubsection{Completion Perforations}

A trip was made with a 4-1/2 inch bit and a 5-1/2 inch casing scraper. Firm cement was drilled from 15,900 to 15,946 feet and the mud conditioned to the top of the float collar at 16,302 feet in the casing liner.

Correlations with both gamma-ray and electric log measurements corresponded through the MA-6 sand (see Fig. 12). A 3-3/8 inch Schlumberger casing gun was run and the casing liner was perforated opposite 93 net feet of the MA-6 sand with four jet shots per foot in four runs with the gun. The completion interval was as follows:

$$
\begin{aligned}
& 15,930 \text { to } 15,916 \text { feet ( } 14 \text { feet) } \\
& 15,903 \text { to } 15,881 \text { feet ( } 22 \text { feet) } \\
& 15,878 \text { to } 15,872 \text { feet ( } 6 \text { feet) } \\
& 15,864 \text { to } 15,858 \text { feet ( } 6 \text { feet) } \\
& 15,842 \text { to } 15,830 \text { feet ( } 12 \text { feet) } \\
& 15,820 \text { to } 15,806 \text { feet ( } 14 \text { feet) } \\
& 15,801 \text { to } 15,781 \text { feet }(20 \text { feet) }
\end{aligned}
$$

Because of problems in setting the production packer, wich are discussed in Section 6.3.8, only the top 58 feet of the perforated interval was available for production.

\subsubsection{Production Packer Setting}

On completing the perforation of the liner for production, a wireline junk basket and gauge ring trip was made to assure clearance for setting the production packer. The hole was found to be in gauge and clean to 15,550 feet, at which depth an 0t is type "WD" packer equipped as shown in Fig. 13 was run and set by wireline. 


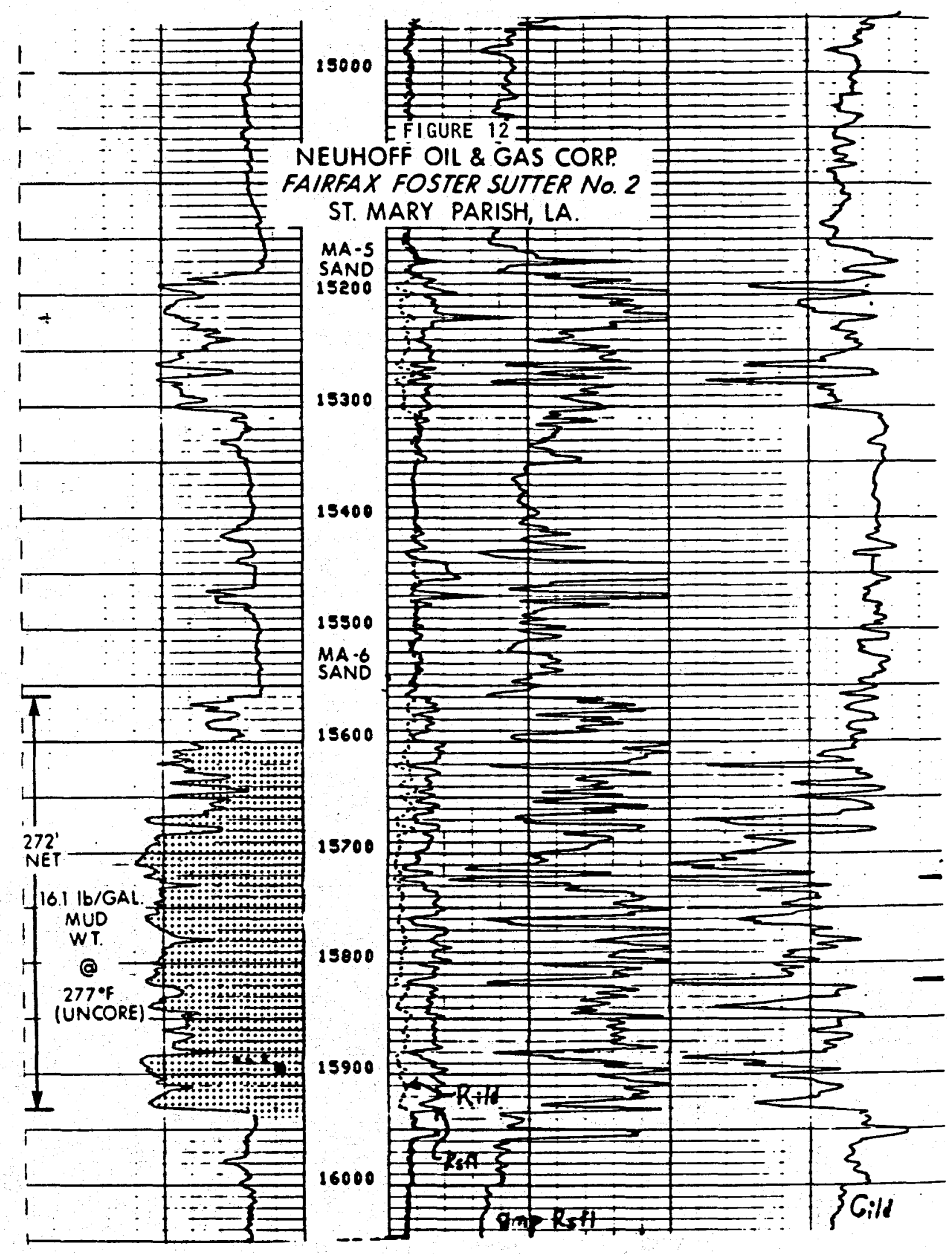


FIGURE 13

GRUY FEDERAL, INC. - DOE

FAIRFAX FOSTER SUTTER NO. 2

BOTTOMHOLE TUBING ASSEMBLY

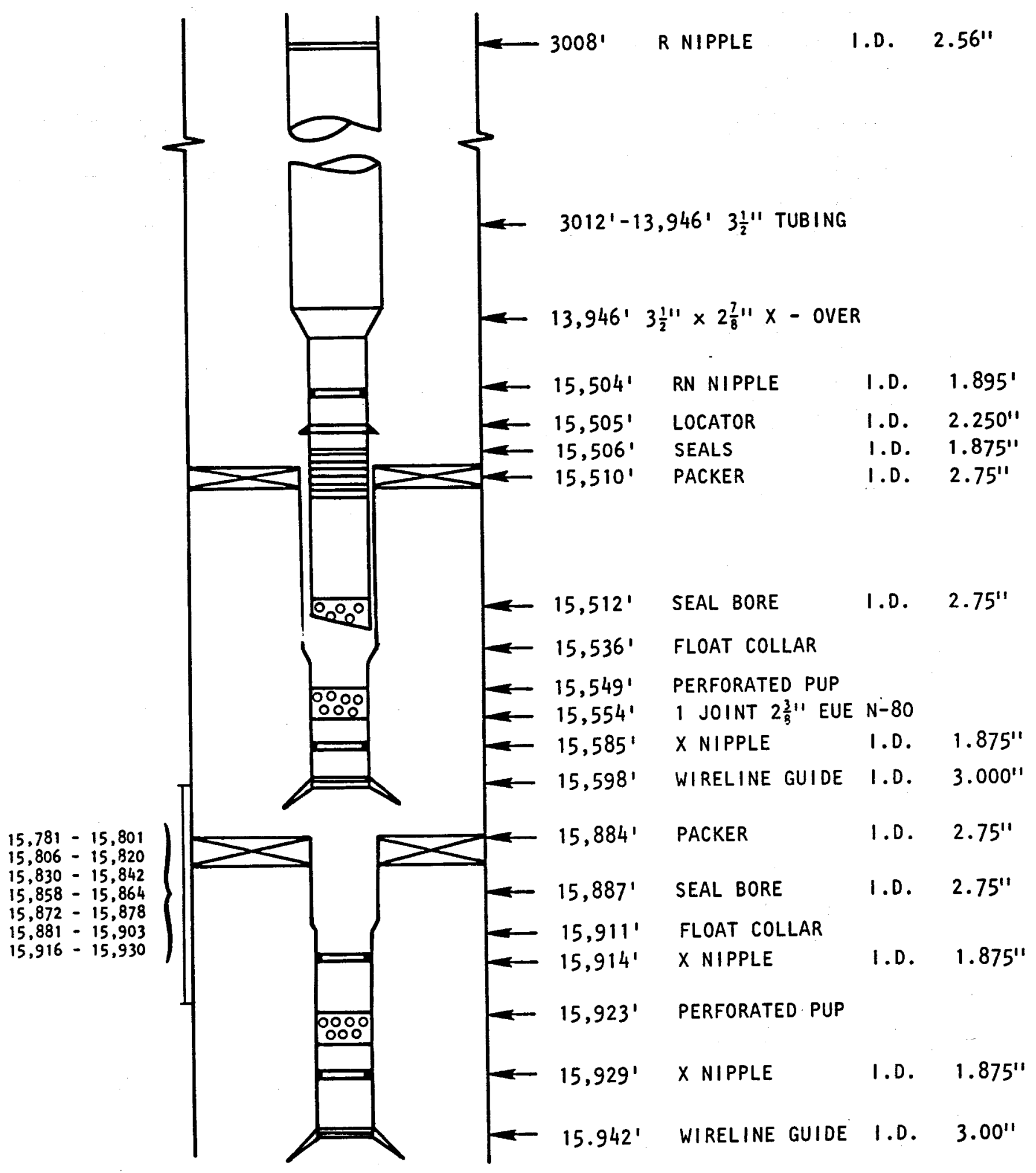


Four feet of seals for the packer were made up and run on the work string to test the packer setting. The seals and packer stringer tagged the packer at the proper depth. The packer held 15,000 1b of weight applied from the drill pipe. It was then tested on the bottom side by applying 1500 psi on the drill pipe for 15 minutes. It held satisfactorily.

\subsubsection{Production Tubing}

After an satisfactory test was obtained, the 3-1/2 inch drill pipe work string was pulled and laid down on the pipe racks in preparation to return it to the rental company.

The 0tis seal assembly, complete with a perforated production tube, locator sub, landing nipple, and flow coupling (Fig. 13) was made up on the bottom of 48 joints of $2-7 / 8$ inch, $7.9-1 \mathrm{~b}$, IJ $3 S S$ tubing and run in the hole, testing each joint internally to 10,000 psi. A crossover sub to 3-1/2 inch, 12.95-1b, PH-6, P-105 tubing was installed and 14,014 feet of $3-1 / 2$ inch tubing run in the hole, testing each joint to 10,000 psi. The packer was tagged at 15,550 feet. The stinger and seal assembly entered the packer bore with $12,0001 \mathrm{~b}$ of weight applied to the packer bore from the locator sub. The applied weight moved the packer down hole from 15,550 feet to 15,691 feet, where $30,000 \mathrm{lb}$ of weight was applied with a very slow weight leak-off as weight was applied. The seals were pulled out of the packer, but circulation could not be established through the tubing. While pulling out of the hole with a wet string of tubing, unsuccessful attempts were made to break circulation each 1000 feet with 3000 psi surface mud pump pressure. The hole was kept full of mud as the tubing was pulled. It was found that the bottom joint of 3-1/2 inch tubing was completely plugged with thick, jelled mud that had to be removed from the tubing with a high-pressure water jet. Each joint of 2-7/8 inch tubing removed from the hole required washing out with a hose. The thick mud was al so between the spacer rings on the seal assembly. This condition followed repeated attempts to condition the mud to correct cement contamination.

A 4-1/2 inch bit and 5-1/2 inch casing scraper were next run in the hole, requiring the rig pumps to break circulation at $7000,14,000$ and 14,130 feet (at top of liner) and every two stands inside the liner. The packer was tagged at 15,691 feet and $10,000 \mathrm{lb}$ of weight set on it. Packer started moving down the hole with $5000 \mathrm{lb}$; at 15,914 feet it would move no farther with 30,000 lb of weight.

The hole was circulated and conditioned for 5-1/2 hours while waiting on oil-base mud to completely displace the contaminated mud system. A total of 885 barrels of contaminated mud was displaced with oil-base mud weighing $16.0 \mathrm{lb} / \mathrm{gal}$. The bit and scraper were pulled out of the hole in preparation to run a new production packer.

When the first ot is packer failed to set properly, Gruy requested ot is Engineering to determine the reason for the failure. Ot is advised that the slip segment of the first packer had not been sufficiently heat-treated to set properly in the high tensile strength $P-110$ casing. A new ot is type "WD" packer was run and set by wire line at 15,510 feet (electric log 
measurements).

Test equipment was rigged up and the tubing joints tested to 10,000 psi. After spacing out the tubing, 35,000 1b were applied to the packer without any packer movement. The packer was satisfactorily tested to 1500 psi from above and below for 30 minutes.

\subsubsection{Christmas Tree}

The tubing was spaced out and hung in the tubing spool. A backpressure valve was installed in the Canfield bushing. The preventer stack was removed and the christmas tree installed. The well was left idle with a plug in the bottom of the tree wile the drilling rig moved out and the saltwater disposal well was drilled.

It was found that safety and flexibility could be improved if the christmas tree were altered for future operations as shown in Fig. 11. 
7.0 SALTWATER DISPOSAL WELL

$7.1 \quad$ General

The saltwater disposal well, located 125 feet from the test well, was drilled after completion of the No. 2 sutter and after the drilling rig moved off the site.

7.2 Design Requirements

1. This disposal well was designed to provide an injection capacity up to $10,000 \mathrm{~B} / \mathrm{D}$ at an injection pressure not to exceed $300 \mathrm{psi}$ and an injection temperature up to $280^{\circ} \mathrm{F}\left(138^{\circ} \mathrm{C}\right)$.

2. The Louisiana Department of Conservation specified that the minimum saltwater aquifer depth in this area was 3400 feet.

3. The Louisiana State Department of Conservation regulations specify that each disposal well must protect fresh water or shallow brackish water sands by:

a. Setting and cementing two complete strings of casing through all fresh or brackish water sands by circulating cement to the surface on each string if no tubing is used, or

b. Cementing one string of casing through the fresh water sands to the surface and isolating the tubing by a production packer inside the second string of casing.

A review of the electric $\log$ on the test well indicated three possible disposal aquifers should be penetrated between 3400 and 4000 feet.

Figure 14 shows the well schematic that meets (a) above.

\subsection{Rig Selection}

Because of the shallow gravel beds and the buried cypress forest known to be in the general vicinity of this site, the risks in drilling a disposal well were compounded; hence, modified turnkey drilling bids were solicited. Gruy agreed to furnish tubular goods, cement and services, and the required electric logs; the drilling contractor agreed to drill the well to total depth and set the various strings of casing for a fixed fee, while the completion work would be performed on a day-rate basis. Howard Water Well Service of Jennings, Louisiana, was the successful bidder. A copy of the contract is provided as Appendix B.

\section{$7.4 \quad$ Drilling Operations}

\subsubsection{Conductor Casing}

Prior to moving in the disposal well rig, 13-3/8 inch OD PEB $54.5 \mathrm{lb} / \mathrm{ft}$, K-55 conductor casing was driven to refusal at 108 feet with a $D-4$ power hammer. 
FIGURE 14

FAIRFAX FOSTER SUTTER NO. 2

SCHEMATIC FOR DISPOSAL WELL

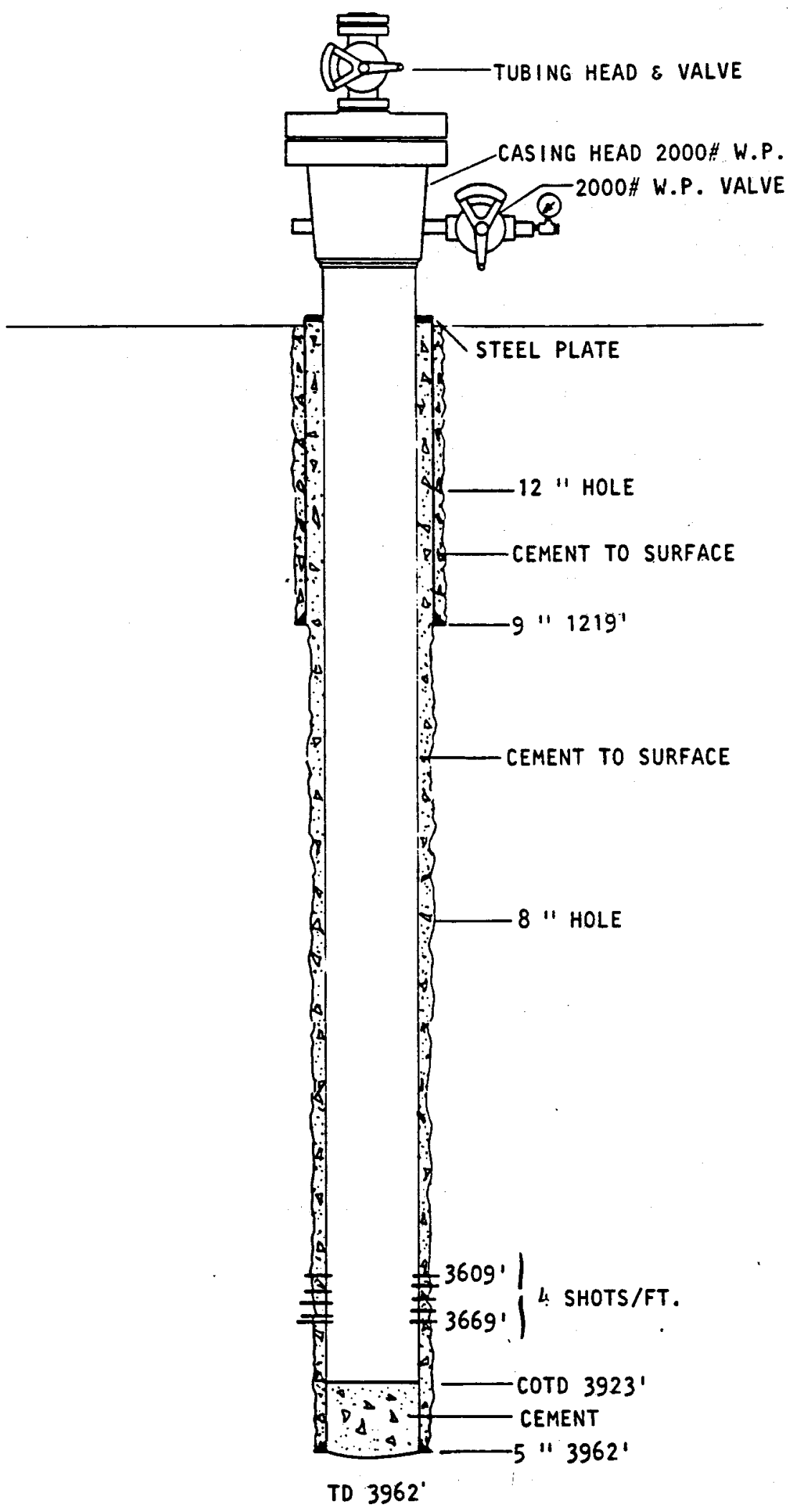


Howard moved their rig onto the site on April 21, 1979. Torrential rains commenced the same day and flooded the entire countryside. Neither the crew nor the supply trucks could return to the rig until April 29.

\subsubsection{Surface Casing}

After rigging up over the 13-3/8 inch $O D$ conductor casing, a 12-1/4 inch hole was drilled to 1220 feet and 1219 feet of 9-5/8 inch $00,36 \mathrm{lb} / \mathrm{ft}$, K-55, ST\&C casing was set at 1213 feet with 205 sacks of HOWCO Lite Weight cement plus 35 percent silica flour and 3 percent $\mathrm{NaCl}$, followed by 200 sacks of $\mathrm{Class} \mathrm{H}$ cement with 35 percent silica flour and 2 percent $\mathrm{CaCl}_{2}$. Cement was circulated at the surface. A BOP stack was nippled up on the 9-5/8 inch casing while the cement set.

\subsubsection{Completion Casing}

An 8-3/4 inch hole was drilled inside the surface casing to a depth of 3962 feet with no unusual problems. This depth was reached on May 12, 1979. After the hole was conditioned, an ISF and Sonic-Caliper log was run from 3964 feet to 1172 feet.

Drill pipe was run to total depth to condition the hole and then laid down preparatory to running 5-1/2 inch, $15.5 \mathrm{lb} / \mathrm{ft}, \mathrm{K}-55$ casing.

The casing was equipped with a HOWCO guide shoe on bottom, a Flowco float collar one joint above bottom, and a centralizer every other joint from total depth to the surface. A total of 3956 feet of casing was set at 3962 feet below the derrick floor datum point. The pipe was cemented by pumping 1000 gallons of mud acid ahead of 650 sacks of HOWCO Lite weight cement plus 3 percent $\mathrm{NaCl}$ plus 35 percent silica flour, tailed in with 250 sacks of $\mathrm{Cl}$ ass $\mathrm{H}$ cement plus 3 percent $\mathrm{NaCl}$ plus 35 percent silica flour. Full returns were maintained throughout the job and cement was recovered at the surface. The plug in the collar held when the pumps were shut down.

\subsection{Completion Operations}

While waiting 48 hours for the cement to set up, the contractor picked up a 2-7/8. inch work string with a 4-3/4 inch bit and conditioned the mud inside the casing to the float collar at 3923 feet. The bit was pulled and CBLgamma-ray-collar logs were run from 3912 feet to 780 feet. The casing bond log indicated good bonding and block squeezing was not necessary.

The work string was again run to the float collar at 3923 feet and all drilling mud inside the casing was displaced with salt water obtained from a nearby source. The work string was laid down, the blowout preventers rigged down, and the injection wellhead installed and tested. The water well rig was then released and moved off the site.

\subsection{Petrophysical Data}

Analysis of the ISF-Sonic log obtained on this well showed the following sands had been penetrated: 
Calculated

Weighted Average

Net Thickness

100 feet

148

74
Porosity $\%$

36.5

33.5

34.0

\subsection{Perforations and Injectivity Tests}

The $B$ sand was selected as the initial disposal sand for the $\mathrm{GeO}^{2}$ test well. The interval from 3609 to 3669 feet was perforated with four shots per foot, using a 4-inch OD casing gun. For convenience, the perforating was accomplished using three 20-foot perforating guns with three separate trips in the hole.

The potential injection sands consist of fine to medium silica grains that vary from unconsolidated to poorly consolidated with argillaceous materials. They are highly susceptible to flowing or sloughing into the wellbore if the well is produced. In order to utilize such aquifers for disposal the static fluid head should be equal to or greater than the aquifer pressure; and under dynamic conditions a differential pressure should always exist from the wellbore to the injection aquifer. Under such conditions, excessive sand production can usually be avoided. Should some circumstance occur that would result in excessive sand production or sedimentation from the injected water, the disposal well could be backwashed using coiled tubing with backpressure held on the sandface.

In order to evaluate injection test data while protecting the disposal well from backflow, it was decided to hold 500 psi backpressure on the formation while perforating each 20-foot section. Further, wile the perforating equipment was out of the hole to change guns, injectivity tests using lease salt water were conducted on the disposal sand.

Operations to complete perforating and injectivity testing proceeded by rigging up Schlumberger's portable mast derrick, wireline perforating equipment, a Halliburton pump truck, and two vacuum trucks full of lease salt water. The perforating and injectivity tests were conducted as discussed above.

\subsection{Injection Well Stimulation}

Based upon the results of the injectivity tests shown in Fig. 15, the perforations from 3669 feet to 3609 feet were acidized with 3000 gallons of $\mathrm{HCl}, 1000$ gallons of $\mathrm{HCl}$ (divested) and 6000 gallons of HF plus 5 gallons of surfactant per 1000 gallons of acid. All acid was displaced with lease salt water. Figure 15 al so shows that the acidizing was successful; the disposal well was capable of taking all anticipated production from the Geo ${ }^{2}$ well without the use of surface pumps. Actual production tests proved that the maximum production was in excess of $7000 \mathrm{~B} / \mathrm{D}$, while the maximum injection pressure ranged up to 90 psig. During the latter stages of the $\mathrm{GeO}^{2}$ test operations, the surface air coolers were bypassed and 
FIGURE 15

FAIRFAX FOSTER SUTTER NO. 2

INJECTIVITY TESTS ON

SALT WATER DISPOSAL WELL

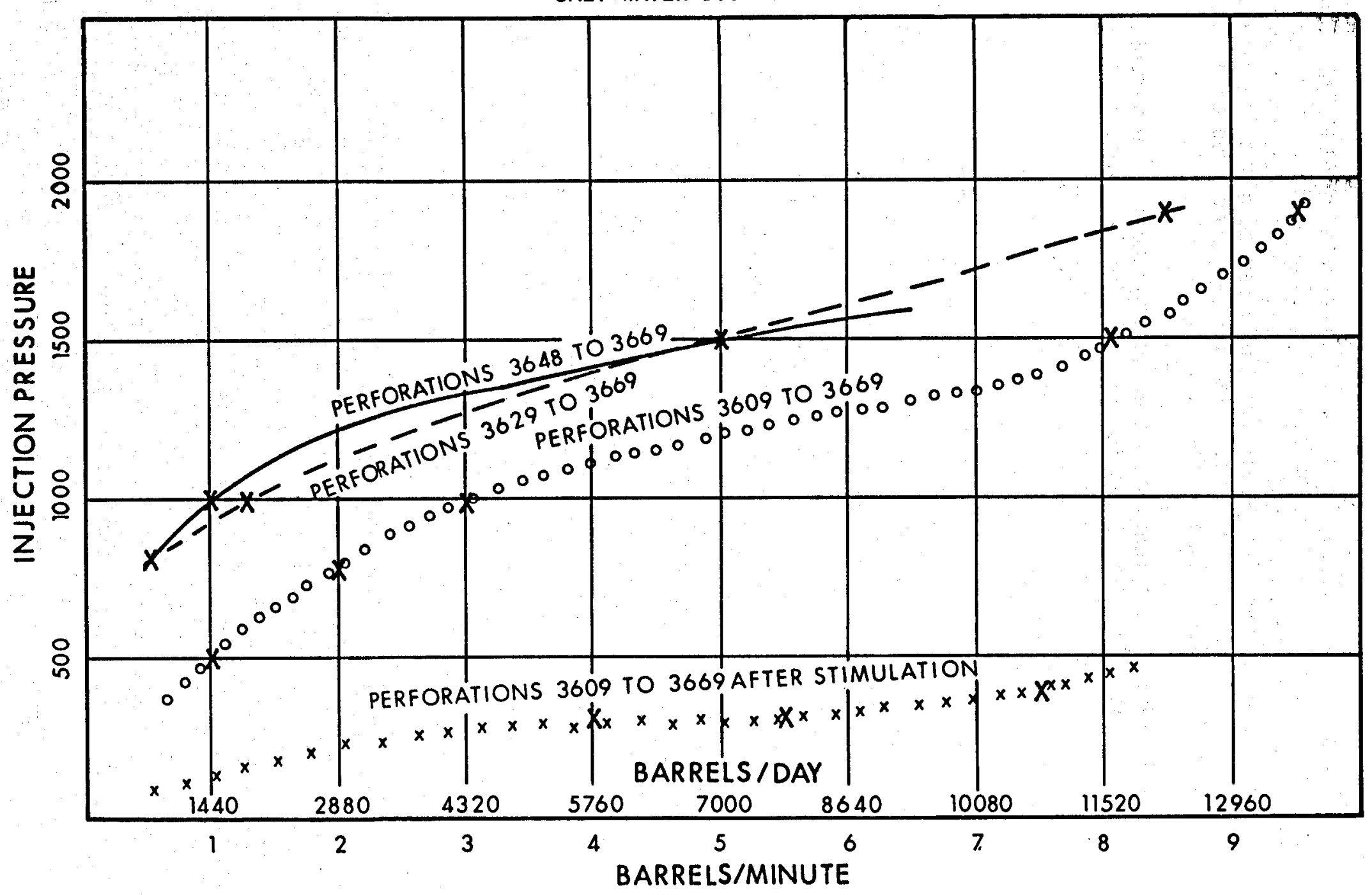


$240^{\circ} \mathrm{F}\left(116^{\circ} \mathrm{C}\right)$ well fluid was injected at a rate of $5100 \mathrm{~B} / \mathrm{D}$ with a maximum surface injection pressure of $120 \mathrm{psig}$. The difference between injection pressures for the hot and the cooled $\mathrm{GeO}^{2}$ water can be accounted for by the decrease in specific gravity of the water at higher temperatures. When the Geo ${ }^{2}$ well was shut in, the injection pressure dropped to zero or to a slight vacuum almost instantaneously.

All stimulation equipment was released and the well was hooked up to the surface production facilities to commence the $\mathrm{GeO}^{2}$ well tests. 


\subsection{TEST OBJECTIVES}

The test on the Gruy-DOE Fairfax Foster Sutter No. 2 well was designed to obtain the maximum amount of information about the $\mathrm{Geo}^{2}$ reservoir rock and fluid properties within the time and funds allotted. These properties are:

- Gas solubility

- Well deliverability

- Formation flow capacity

- Wellbore damage

- Aquifer geometry

- Distance to existing boundaries

- Chemical composition of the water

- Chemical composition of the gas

- Physical properties of the water

- Physical properties of the gas.

In addition, the performance of downhole and surface equipment exposed to these high-pressure, high-temperature brines was unknown. For example, the maximum temperature to which the Hewlett-Packard quartz crystal gauge is calibrated is $302^{\circ} \mathrm{F}\left(150^{\circ} \mathrm{C}\right)$, which is near the expected bottomhole temperature. Similarly the injectivity performance of shallow Miocene sands subjected to this temperature and injection rate has not been previously studied. All of these factors were considered when designing the test procedures. 
9.0 SURFACE TESTING FACILITIES

9.1 Design

A schematic of the surface equipment is shown in Fig. 16. The surface testing facilities were designed to accommodate hot brines at rates up to $10,000 \mathrm{~B} / \mathrm{D}$ and temperatures as high as $350^{\circ} \mathrm{F}\left(177^{\circ} \mathrm{C}\right)$. The surface equipment was constructed for operating pressures less than 300 psi, since the bulk of the pressure drop occurs at the chokes in the wellhead.

\subsubsection{Piping}

All main line surface piping was 3 -inch, API (5L), Schedule 80 , buttwelded line pipe rated to $1850 \mathrm{psi}$ at temperatures up to $250^{\circ} \mathrm{F}\left(121^{\circ} \mathrm{C}\right)$. The valves in the system were trinmed with T-24 steel with hightemperature packing.

\subsubsection{Separator}

The test separator was a conventional three-phase, 42-inch $\times 10$-foot horizontal separator in which the standard 2-inch dump valves were replaced with 3-inch valves. The working pressure rating of the vessel was $1440 \mathrm{psi}$; however, operating pressure never exceeded $280 \mathrm{psi}$. In order to withstand the high temperatures, the liquid-level float was fabricated from Teflon". The fluid retention time was approximately 30 seconds at the maximum design throughput of $10,000 \mathrm{~B} / \mathrm{D}$. A photograph of the separator is shown as Plate 1.

\subsubsection{Metering}

The liquid drain from the separator was split into two streams, each containing a $10,000 \mathrm{~B} / \mathrm{D}$ HOWCO turbine meter with digital readout. A 100-bbl calibration tank was provided for periodically calibrating each meter. The gas production from the separator was measured using a 3-inch flange-type orifice meter with a 1/2-inch orifice plate and a Barton recorder (see Plate 1 ).

\subsubsection{Air Cooler}

In order to measure liquid volumes using the calibration tank, it was necessary to cool the water below its saturation temperature at atmospheric pressure. Additionally, the compatibility of the disposal aquifers with these hot brines was unknown. For these reasons a fan-type aircooled heat exchanger capable of transferring heat at a rate of $23,400,000$ $\mathrm{Btu} / \mathrm{hr}$ was installed in the system. The cooler was capable of reducing the water temperature from $350^{\circ} \mathrm{F}\left(177^{\circ} \mathrm{C}\right)$ to $190^{\circ} \mathrm{F}\left(86^{\circ} \mathrm{C}\right)$ at a throughput rate of $10,000 \mathrm{~B} / \mathrm{D}$ per day when the ambient temperature was $100^{\circ} \mathrm{F}\left(38^{\circ} \mathrm{C}\right)$. The cooler, shown in Plate 2, contained two 120-inch diameter fans, each driven by a 25-hp electric motor. The overall dimensions of the horizontal skid-mounted cooler were 32 feet long, 11 feet wide, and 92 inches high. 
FIGURE 16

FAIRFAX FOSTER SUTTER N0.2 SURFACE FACILITIES FOR TESTING 


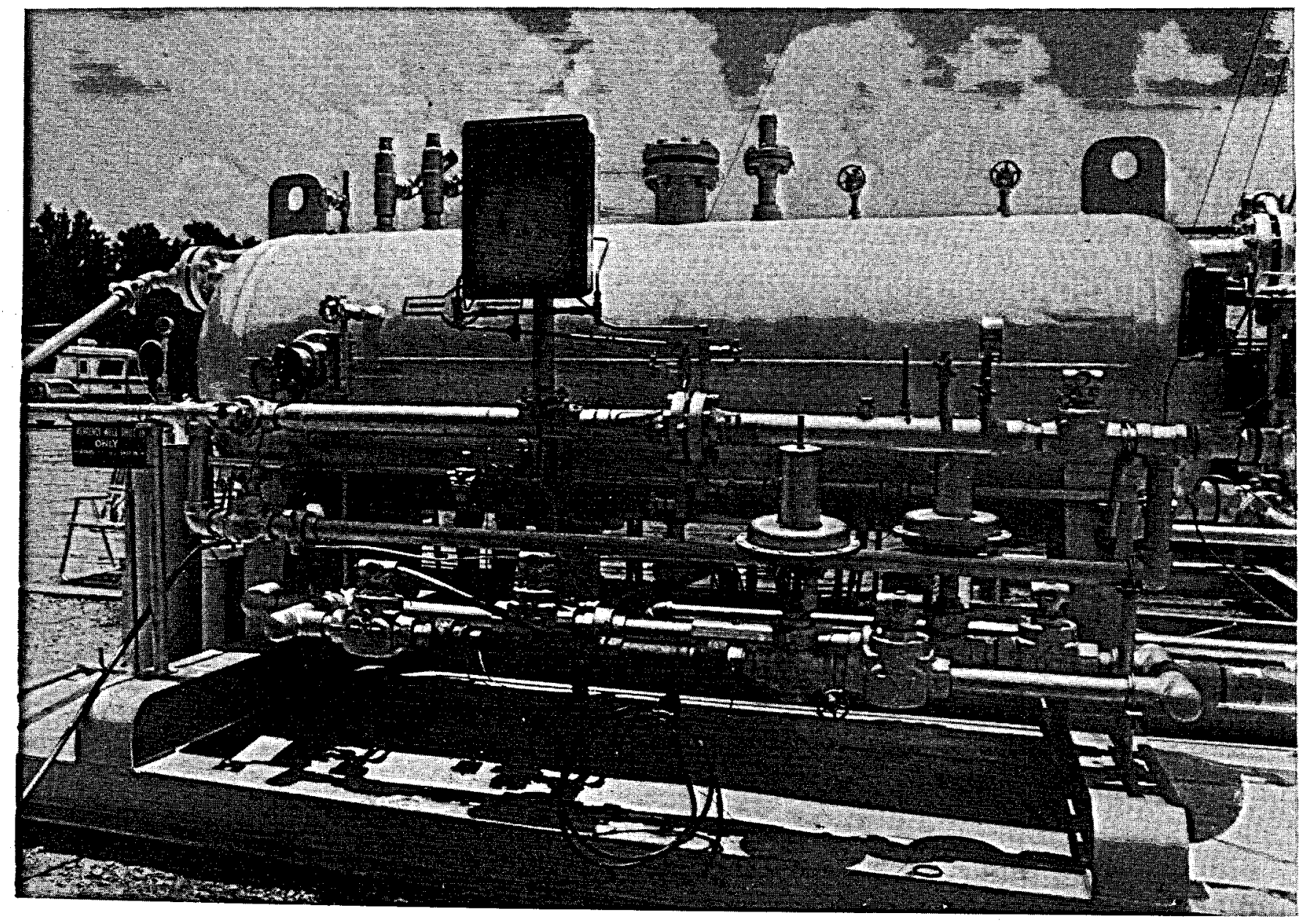

Plate 1

Separator 


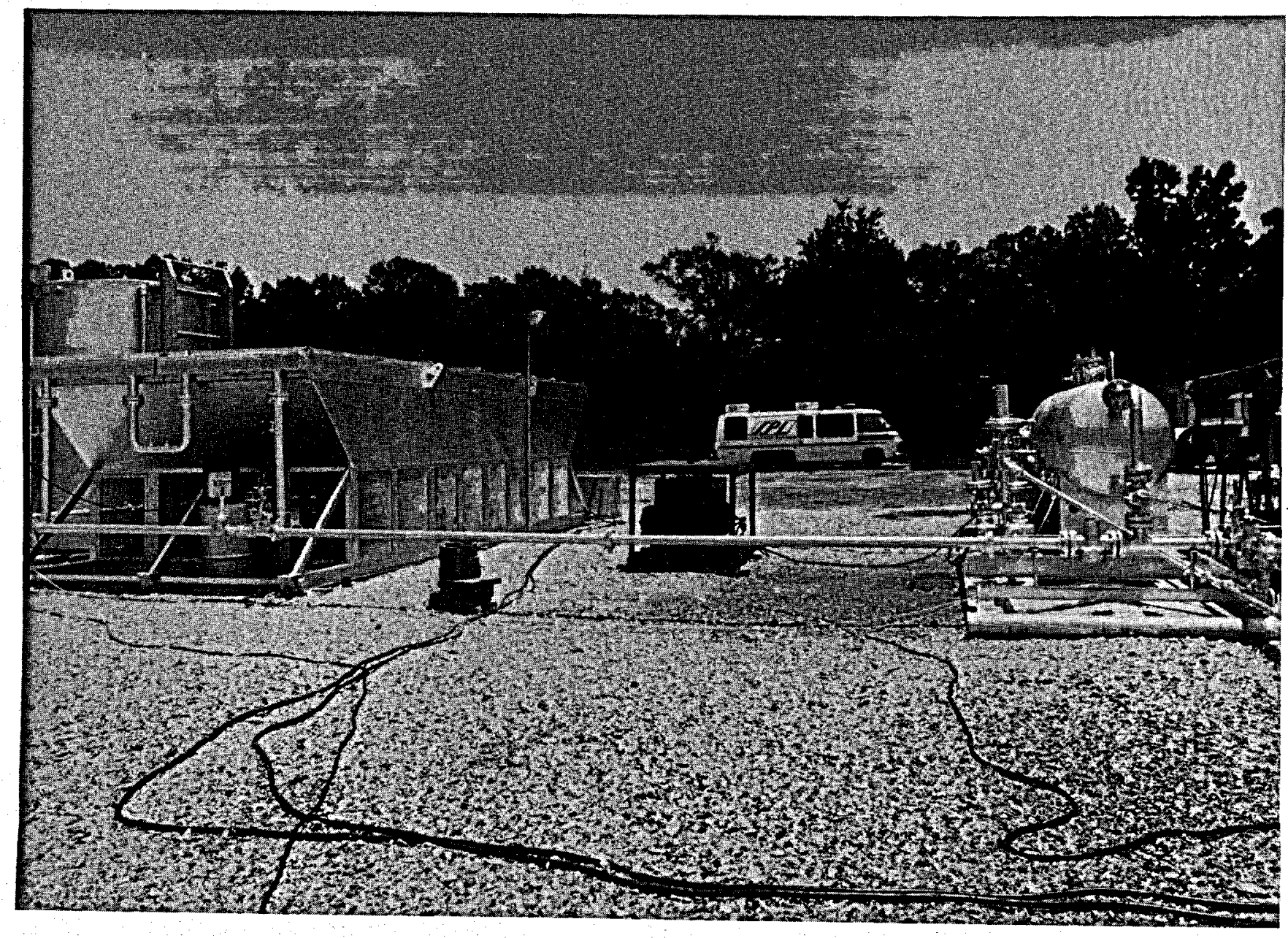

Plate 2

Cooler 


\subsubsection{Filters}

Prior to disposal, the produced brine was filtered through a dual-tower replaceable cartridge filter. The cartridges retain particles 75 microns or larger in size and the cartridge elements can withstand temperatures up to $250^{\circ} \mathrm{F}\left(121^{\circ} \mathrm{C}\right)$.

\subsubsection{Injection Pumps}

Downstream from the filters were diesel-driven centrifugal pumps capable of delivering $10,000 \mathrm{~B} / \mathrm{D}$ at a pressure of 125 psi above suction pressure, manifolded in parallel with common suction and discharge. The pumps were intended for injecting the brine into the disposal well and transferring water from the calibration tank to the disposal well.

\subsubsection{Safety Sensors}

One low-pressure and three high-pressure sensors were installed in the surface flow lines to activate the safety valves on the wellhead in case pressure problems developed in the system. One high-pressure sensor was placed between the data header and the separator to detect any pressure rise resulting from sand erosion of the chokes; the second was installed ahead of the cooler to shut the well in if scale buildup occurred in the cooler; and the last was placed ahead of the injection well to terminate production if the injection pressure rose above $400 \mathrm{psi}$. The low-pressure sensor was installed between the separator and the cooler to stop flow in case a serious leak in the surface facilities occurred.

\subsection{Data Collection}

A data header was assembled ahead of the separator to monitor and record data at a central site. This manifold contained a sonic sand detector, a continuous-recording thermometer, a scale coupon, and valving parts to collect full well stream samples. Pressure and temperature recorders were installed on both sides of the cooler to monitor inlet and outlet temperatures and to detect the occurrence of scale build-up in the cooler tubes if the pressure differential increased. The data collection area is shown in Plate 3 .

A dual-pen pressure recorder was attached to the tubing and casing annulus to detect any fluid communication wich might occur outside the tubing or around the packer.

At the wellhead a 10,000-psi deadweight pressure gauge was installed to measure the surface flowing and shut-in tubing pressures periodically, and a continuous pressure recorder was attached to the injection well.

\subsection{Performance of Surface Equipment}

Throughout the entire cleanup and testing period the surface equipment performed exceptionally well. Early in the test the buildup of scale in most of the surface equipment became excessive and a scale inhibitor 


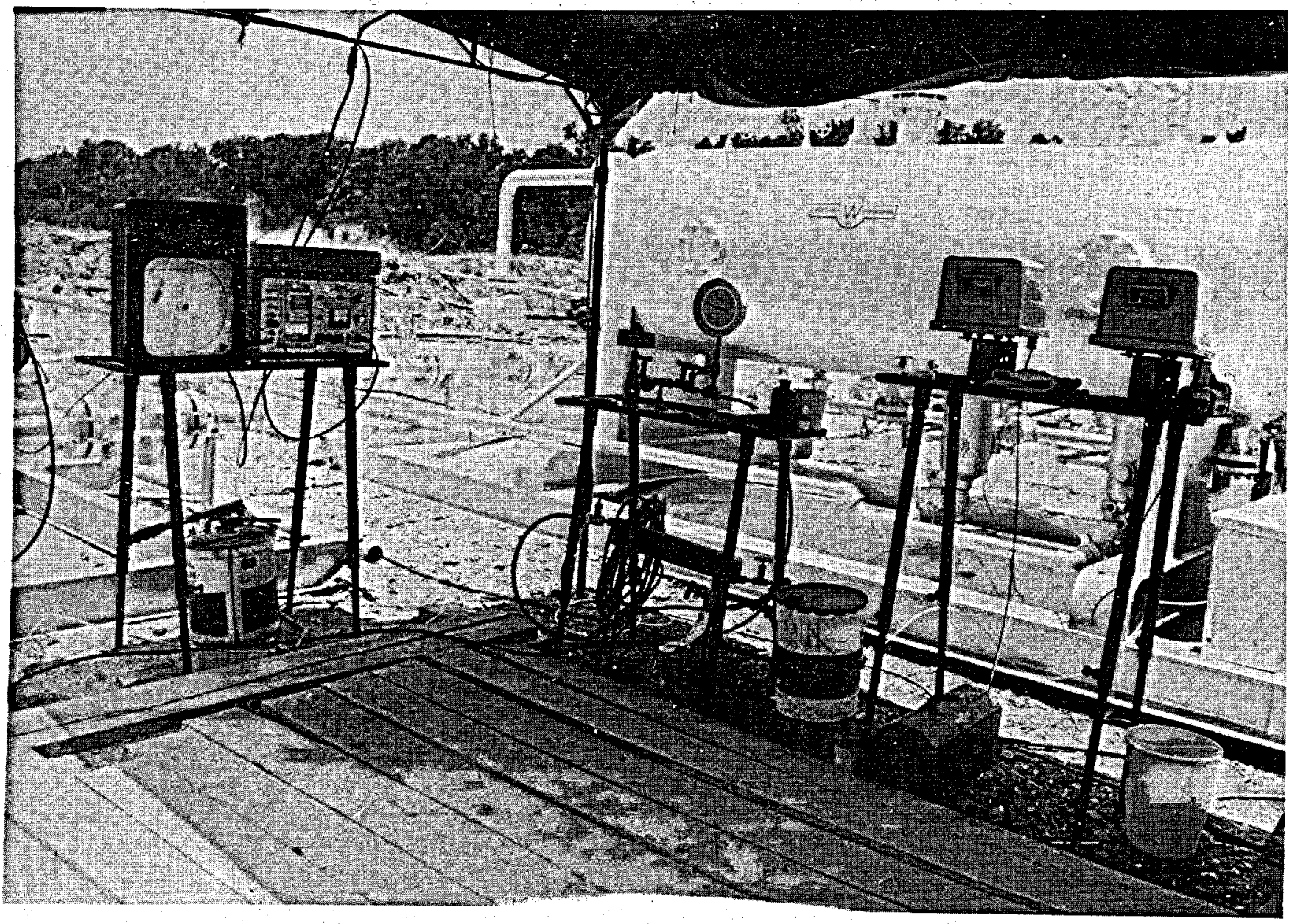

Plate 3

Data Collection Area 
(NTC-S621, a phosphonate compound) was injected into the system upstream from the positive choke at an average rate of 10 gallons per day. This treatment was successful in preventing additional scale buildup but did not el iminate the scale already deposited.

One of the few problems which arose during the cleanup period was the failure of both electric motors on the cooler. The bearings in both motors burned out after only 10 minutes of operation. The motors were immediately replaced with larger (30-hp) ones and no further problems with the cooler occurred.

Because the scale deposit on the HOWCO turbine meters reduced the crosssectional area available to flow, the meter readings were too high, as was confirmed by calibrating the meter against the tank. After the 72-hour flow test the scale deposits inside the surface facilities were removed with hydrofluoric acid. During the second flow test the fluid was continuously treated with scale inhibitor and no further scaling problems occurred.

The injection well took fluid at pressures equal to or less than the output pressure of the filters and the booster pumps were never used for injection. They were utilized, however, to transfer water from the calibration tank to the disposal well after each meter prover test. 
10.1 Tubing Obstruction and Well Head Problems

In order to prepare the well for testing operations, Otis Engineering rigged up a portable mast and installed a Jubricator on top of the swab valve. The blanking plug was pulled from the Canfield bushing and the DR plug was retrieved from 2952 feet. At that time the wellhead pressure rose to 4675 psig. To ensure that the Hewlett-Packard quartz crystal gauge would pass freely to bottom, a sinker bar was run on a wire line. An obstruction was encountered at 15,543 feet which was diagnosed as heavy thick mud. Figure 13 shows that the top of the bridge was above the top of the perforated pup joint.

The well was placed on production in an attempt to unload the plug from the tubing. The master gate valves in the wellhead were difficult to open and the valves began leaking slightly through the lubricating ports. While waiting on a WKM crew and valve parts, the well was flowed to the pit at various flow rates for 6 hours and 40 minutes. The final flowing pressure was 2396 psig.

The DR plug and the blanking plug were reinstalled and the inner workings of both master gate valves were replaced. The tree was tested to 10,000 psig for 30 minutes without leaking and the valves functioned satisfactorily thereafter... Both plugs were then removed.

The well was again flowed to the pit through an 18/64-inch positive choke and a 15/64-inch adjustable choke in order to unload the material plugging the tubing. At the end of 5 hours, the well was flowed through the separator for 1 hour and a gas-water ratio of $20.4 \mathrm{cu} \mathrm{ft} / \mathrm{bbl}$ was measured. The well was then flowed to the pit for another 90 minutes and shut in. The flowing tubing pressure prior to shut-in was 2409 psig and the average flow rate was $5078 \mathrm{~B} / \mathrm{D}$.

An Otis wireline unit was rigged up and an impression block tagged an obstruction at 15,556 feet. The impression block showed that the obstruction was probably dehydrated mud. Several runs with a 1-1/2 inch sample bailer recovered thick, heavy mud and sand. Because the high temperature increased the line stretch, wireline depth measurements were inaccurate, but it was apparent that little progress in removing the plug was being made.

The well was again flowed through the 18/64-inch positive and 15/64-inch adjustable chokes for approximately $2-1 / 2$ hours in an attempt to remove the obstruction. The static surface pressure was 4643 psig and the flowing tubing pressure at the time of shut-in was 2707 psig.

An 0tis drive-down bailer was run several times to a depth of 15,553 feet and each time 4 to 6 inches of thick mud and sand were recovered. Operations to clear the tubing of the obstruction were abandoned on May 23. The X-nipple located at 15,585 feet, originally intended to latch the 
Amerada gauges, was blocked, necessitating a change in the planned operating procedure.

\subsection{Hewlett-Packard Gauge Problems}

A single-conductor cable unit with a high-pressure lubricator was moved on location and rigged up. A Hewlett-Packard (HP) quartz crystal gauge was run in tandem with a temperature logging device and a casing-collar locator. The temperature gauge recorded a surface temperature at $83^{\circ} \mathrm{F}\left(28^{\circ} \mathrm{C}\right)$ and the HP gauge recorded a static surface pressure of 4630 psia, which compared favorably with the value of 4642 psig measured with the deadweight tester. Periodically the gauge was stopped to record the pressure in order to estimate the static pressure gradient. When the gauge reached a depth of 11,750 feet and the pressure reached approximately 10,200 psia, the signal from the gauge to the surface ceased. The assembly was run to a depth of 15,573 feet where the top of the obstruction was encountered. This depth was confirmed by correlating the collar locator log with the bottomhole assembly as it was installed. The temperature at this depth was $268^{\circ} \mathrm{F}\left(131^{\circ} \mathrm{C}\right)$. As the gauge was pulled from the well the signal reappeared at approximately 11,000 feet.

The gauge was retrieved and another HP gauge was run in tandern with two Amerada RPG-3 gauges with maximum-recording thermometers. Again the signal vanished at approximately the same depth and pressure. All three gauges were retrieved. Both maximum-recording thermometers registered a temperature of $274^{\circ} \mathrm{F}\left(134^{\circ} \mathrm{C}\right)$. The measured pressures as a function of depth for the two Amerada gauges and one HP gauge are shown in Table 2.

A third HP gauge was run, but it also failed at approximately the same depth. A second surface signal processor was tried, but again signal failure occurred at the same depth. The cause of these failures has not been identified; however, the integrity of the single-conductor cable is suspect. A report by the electrical wireline company is included as Appendix C.

The failure of the HP gauges to function at bottomhole conditions limited the measurement of the downhole pressures to Amerada RPG-3 gauges. Since the X-nipple at 15,585 feet originally intended to house the gauges was bridged by the dehydrated mud, the operating plan was modified to latch the gauges in the RN nipple at 15,504 feet. Several attempts were made to seat the landing device in the nipple without success. The gauges were pulled, recalibrated, and hung on the wireline with 500 pounds of sinker bars at 13,900 feet in preparation to commence testing. 


\section{TABLE 2}

COMPARISON OF AMERADA AND HEWLETT PACKARD

PRESSURES VERSUS DEPTH

\begin{tabular}{|c|c|c|c|}
\hline $\begin{array}{l}\text { DEPTH } \\
\text { (feet KB) }\end{array}$ & $\begin{array}{l}\text { AMERADA GAUGE } 1 \\
\text { (psia) }\end{array}$ & $\begin{array}{l}\text { AMERADA GAUGE } 2 \\
\text { (psia) } \\
\end{array}$ & $\begin{array}{l}\text { HEWLETT PACKARD } \\
\text { (psia) }\end{array}$ \\
\hline 0 & 4671 & 4667 & 4630 \\
\hline 1000 & - & - & 4756 \\
\hline 2000 & 5641 & 5631 & -- \\
\hline 3000 & 6128 & 6115 & 6077 \\
\hline 5000 & 7093 & 7076 & 7036 \\
\hline 7000 & 8050 & 8041 & 7990 \\
\hline 9000 & 9011 & 8989 & 8934 \\
\hline 11000 & 9963 & 9945 & 9878 \\
\hline 13000 & 10912 & 10881 & -- \\
\hline 15000 & 11834 & 11816 & -- \\
\hline 15490 & 12046 & 12036 & -- \\
\hline
\end{tabular}

Corrected to middle of perforations 15855

12219

12209

12194 


\subsection{TEST PROCEDURE}

The test procedure for the Fairfax Foster Sutter No. 2 included several preliminary flow periods to clean the well, test the surface facilities, and evaluate the injectivity potential of the saltwater disposal well: Following these preliminary tests, a sequence of flow and buildup tests was made in order to evaluate reservoir parameters and the flow characteristics of the well. This particular series of tests included a 3-day drawdown followed by a 6.5-day buildup, an 11-day drawdown, and finally a 19.8-day buildup. Figure 17 is a representation of the test history of the well showing the pressure and production behavior during the cleanup and test periods.

The test prognosis anticipated the use of a Hewlett-Packard (HP) surfacerecording bottomhole pressure gauge throughout the tests, but as discussed in Section 10.2, difficulties with the equipment precluded this. Rather than further delay the testing procedure by attempting to correct the malfunctions, it was decided to abandon the HP gauge and proceed to run the tandem Amerada RPG-3 gauges for bottomhole pressure measurements. The tubing string of the well had been equipped with an RN landing nipple above the packer so that the gauges could be latched in the recording position and the slick line withdrawn. Several runs were made to latch the tools in position, but the latching equipment failed to operate properly. The Amerada gauges then were redressed, recalibrated, and run near the bottom of the 3-1/2 inch tubing and hung rather than latched in that position on the wire line.

\subsection{First Flow Test}

The well was opened on a 24/64-inch positive choke, which yielded a rate of slightly over $5000 \mathrm{~B} / \mathrm{D}$. Within 12 hours scale buildup was observed on the turbine meters and separator dump valves. After 20 hours scaling problems had become so severe that it was necessary to dump the separator manually at frequent intervals. A scale inhibition system was installed to inject inhibitor upstream of the positive choke. This retarded the deposition of more scale but did not remove substantial quantities of scale already deposited. One of the two turbine meters in service was shut in and the turbine vanes were cleaned manually. There can be little doubt that scale deposition in the turbine meters caused them to read higher than actual production. The meter calibrations were checked against the test tank and a calibration factor of 0.82 was derived." Water production volumes were al so calculated fron the measured gas volumes and assuming a constant gas-water ratio. This method gave a calibration factor of 0.803 , which agrees closely with the previous one. The latter method was used throughout the analysis to compute corrected water production rates.

\section{$11.2 \quad$ First Buildup Test}

Following the flow period of 71.75 hours, the well was shut in for a pressure buildup test. After 90 hours of shut-in the two Amerada gauges were pulled so that the charts could be processed and the gauges could be re- 
FIGURE 17

FAIRFAX FOSTER SUTTER NO 2

PRESSURE PRODUCTION HISTORY DURING TEST

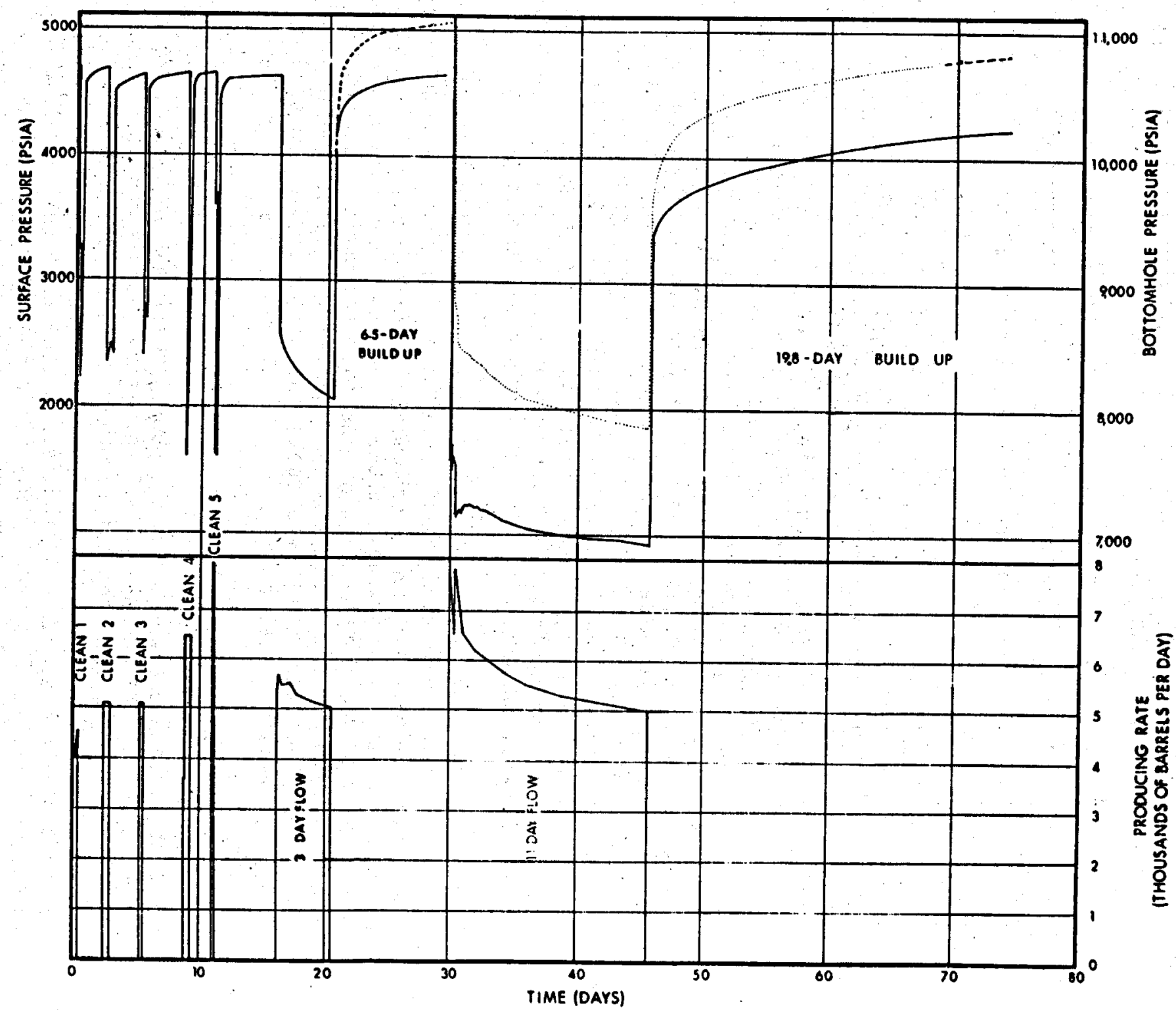


dressed and rerun. During the pulling operations, the stuffing box on the lubricator developed a small leak and an unmeasured volume of fluid escaped, causing a loss of 6 psi in surface pressure. The pressure charts were recovered and indicated that pressures had not been recorded during the entire period they were in the hole. The well remained shut in for an additional 68 hours while the surface pressure buildup was recorded with a deadweight tester at the surface (see Plate 4 ).

Another attempt to use the surface-recording HP gauges was made 40 hours after retrieving the Amerada gauges. This time all equipment functioned properly and the HP gauges remained in the hole for most of the remaining test. The last 38 hours of the buildup, therefore, had measured bottomhole pressures.

\subsection{Second Flow Test}

After the buildup test of 6-1/2 days, the well was again placed on production. The well was opened on a $6 / 64$-inch adjustable (A) choke and the choke size was gradually increased to $30 / 64$ inch over a period of 20 minutes, at which time production had reached approximately $7000 \mathrm{~B} / \mathrm{D}$. About 2 hours later the well was changed from a 30/64-inch adjustable to a 30/64-inch positive $(P)$ choke. About 6 hours after opening the well to flow, another attempt was made to increase the flow rate by opening the adjustable choke in stages while maintaining flow through the 30/64-inch positive choke. The rate increased to approximately $7700 \mathrm{~B} / \mathrm{D}$ on $30 / 64-$ inch (P) plus 15/64-inch (A) chokes, at which point the bottomhole pressure assembly began to move up the hole. The adjustable choke was closed to 14/64 inch and the bottomhole assembly stabilized. The well was then produced through both wings of the tree with $30 / 64$-inch positive and 14/64-inch adjustable chokes for the remainder of the flow test.

Throughout the test both the production rate and the bottomhole pressure decreased, which indicated that a multiple flow rate analysis would be required. At least part of the decrease in rate was caused by a continual plugging of the adjustable choke by scale. Scale inhibitor was injected through the wing containing the positive choke, but the wing containing the adjustable choke was not protected against scaling. By the end of the test the adjustable choke was found to be almost completely closed by deposited scale.

\subsubsection{Hot Injectivity Test}

The second flow test was planned to be discontinued at the end of 10 days. However, shortly before the end of this time, it was decided to bypass the coolers and attempt a hot-water injection test to evaluate the injectivity of the disposal well during the injection of such a fluid. Prior to the test the disposal well had been taking approximately $5000 \mathrm{~B} / \mathrm{D}$ at an injection pressure of approximately 50 to $55 \mathrm{psi}$ and a surface temperature of $111^{\circ} \mathrm{F}\left(44^{\circ} \mathrm{C}\right)$. Shortly after the cooler was bypassed the surface pressure increased to 115 to $120 \mathrm{psi}$ and the surface temperature to $240^{\circ} \mathrm{F}$ $\left(116^{\circ} \mathrm{C}\right)$. The increased pressure can be attributed to the lower specific 


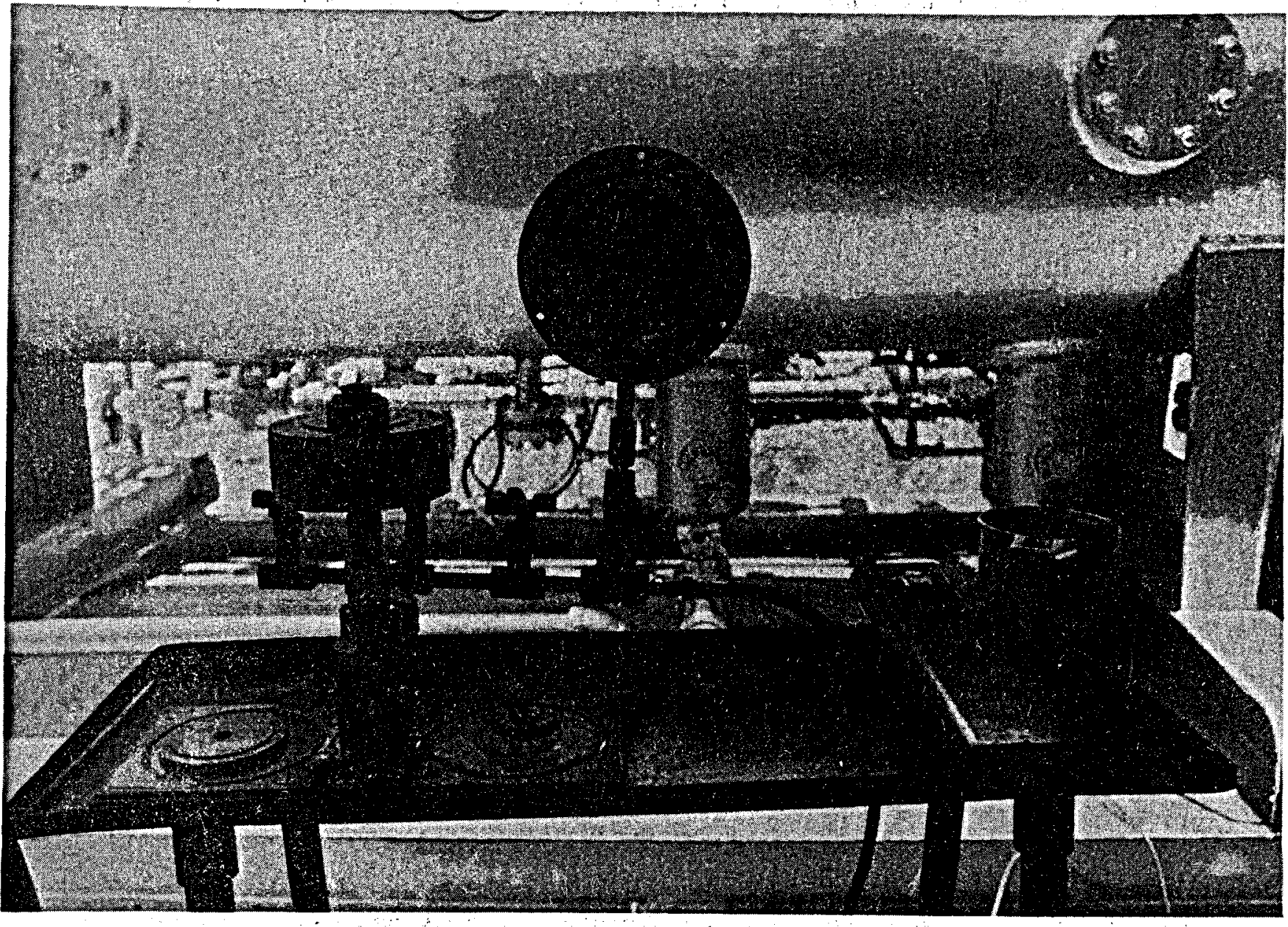

Plate 4

Deadweight Tester 
gravity of the injected fluid at the higher temperature. Sand face injection pressure probably remained nearly constant.

A second observation during the hot-water injection test was the thermal expansion of the injection well tubulars. The injection well had been completed with a high-temperature cement, and a bond $\log$ run after cementing indicated good bonding throughout the length of the string. Because of the good completion, the vertical expansion of the tubulars was minimal, never exceeding 3 or 4 inches throughout the test.

Admittedly, the 28-hour hot-water injection test did not conclusively demonstrate the effect of long-term hot-water disposal on clay minerals and injectivity. However, it does indicate that hot-water injection is a possible alternative to the more expensive operation of cooling and injecting cold water.

\subsection{Final Buildup Test}

The final portion of the test procedure involved a 19.8-day buildup test following the final flow. The HP gauge continued to function during the first 15 days of the test. At that time the signal was lost and no more readings could be obtained.

An attempt was made to recover the HP gauge after it malfunctioned, but the wireline could not be pulled through the flow tubes in the stuffing box and became stuck. At that point it became necessary to kill the well in order to recover the wireline and HP equipment. While preparations were being made, the well remained shut in for an additional 5 days and surface pressures were measured with the deadweight tester. 
The highly variable flow rates during the early tests, the variable rates during the 3-day and 11-day flow tests, and the failure of the reservoir to reach static pressure during any shut-in period indicated that multiple rate analysis would be necessary to interpret the data obtained. This type of analysis employs the superposition theorem instead of the log time relationship used in constant rate analyses. A complete discussion of the theory is given in Appendix ' $D$.

\subsection{Superposition}

A11 symbols and equations are shown at the end of Appendix $D$, but it seems advisable at this point to define $X_{n}$. ' $X n$ is an independent variable that accounts for the presence of multiple transients in the reservoir which occurred during previous flow and shut-in periods. By use of this transformation, the data are corrected to provide the straight-line segment needed for the flow capacity determination.

\subsubsection{Rate Measurements}

For the analysis of the final three tests on this weil (two buildup and one drawdown) it was decided to analyze the last buildup first, since it had the most reliable data and was most amenable to analysis. However, as can be seen from the $X_{n}$ function, it is necessary to have rate data for the entire test program in order to compute $x_{n}$ for the buildup.

It was mentioned in Section 9.3 that scaling seriously affected the accuracy of the turbine meters, especially during the 3-day flow test. Also, during the 10-day flow test it was noted that some scatter existed in the production rate measurements and that in some cases rates had not been recorded during periods of known rate changes. These severe rate changes occurred only during the first hour of the flow test and during the cleanup. Since inconsistencies or inaccuracies in some of the data could result in erroneous computation of the superimposed rate/time function, procedures were developed to interpolate production data where they were missing, correct the production data during the 3-day test when the meter was found to be inaccurate, and smooth the production data during the 11-day test.

Missing production data, most of which were lost during the early cleanup tests, were estimated by orifice meter calculations, using the choke size and flowing wellhead pressure. Errors in these estimates could be tolerated because this information has little effect on the computed value of the independent variable. Production data during the 3-day flow test were estimated using the gas production data and a constant gas-water ratio recorded during later flow tests. Production data during the 10-day test were smoothed using a correlation of surface deadweight tester pressure versus measured production rate. In most cases the smoothed data were within 2 percent of the measured data. 
The superimposed rate/time function was computed by dividing the test times into 969 periods varying in duration from 1 to 240 minutes.

\subsection{Analysis of Second Buildup Data}

For the analysis of the second buildup, the superimposed rate/time function was plotted against the pressure (Fig. 18). Eq. D-24 (Appendix D) shows that such a plot should result in a straight line with a slope equal to $m$ and an intercept of $p^{*}$ (the original pressure) if the reservoir were infinite in areal extent. It is immediately apparent from the shape of the curve that the reservoir is not infinite and that at least one linear barrier exists.

\subsubsection{Intersecting Faults}

Two interpretations of the data are possjble. The first interpretation, using a technique developed by Prasad, assumes that the well lies along the line bisecting the angle created by the intersection of two faults. These two faults intersect at an angle of approximately $120^{\circ}$. Using the slope of the line from the early portion of the curve to determine the flow capacity and the formation permeability, it was found that the effective flow capacity was $827 \mathrm{md}-\mathrm{ft}$ and the permeability was 14.3 md. Two methods were then used to compute the distance to the first barrier. The first method uses the time at which the two straight lines intersect, which gave an indicated distance of 881 feet to the first linear barrier. The second method uses the deviation of the pressure buildup curve from the straight line and uses Eq. D-37. This method gave an indicated distance of 934 feet to the first linear barrier, which is in substantial agreement with the first computation.

The second straight line extrapolated to a pressure of 11,162 psia. The original measured pressure was 11,300 psia at 13,865 feet. This is a small difference when graphical extrapolations are used.

The skin effect was also computed using a modified form of Eq. D-25, showing a small negative damage (improvement) of -1.97 in the area near the well lbore.

\subsubsection{Parallel Faults}

The second interpretation, based on a technique presented by Tiab and Kumar $^{8}$, assumes that the well is situated midway between two parallel faults; each 881 feet from the well. In this case the second straight line would not exist and the plotted curve would be concave upward, approaching the final static pressure asymptotically.

As was mentioned previously, the HP pressure measurement system failed to function during the last 5 days of the second buildup test and only deadweight surface pressure measurements were available. However, a trend of the difference between surface and subsurface pressures had been established (see Fig. 19), and surface pressures could be extrapolated to subsurface pressures on the basis of this trend. When the last 5 days of 
FIGURE 18

FAIRFAX FOSTER SUTTER NO. 2

PRESSURE VS SUPERIMPOSED TIME

FOR SECOND BUILD UP

온

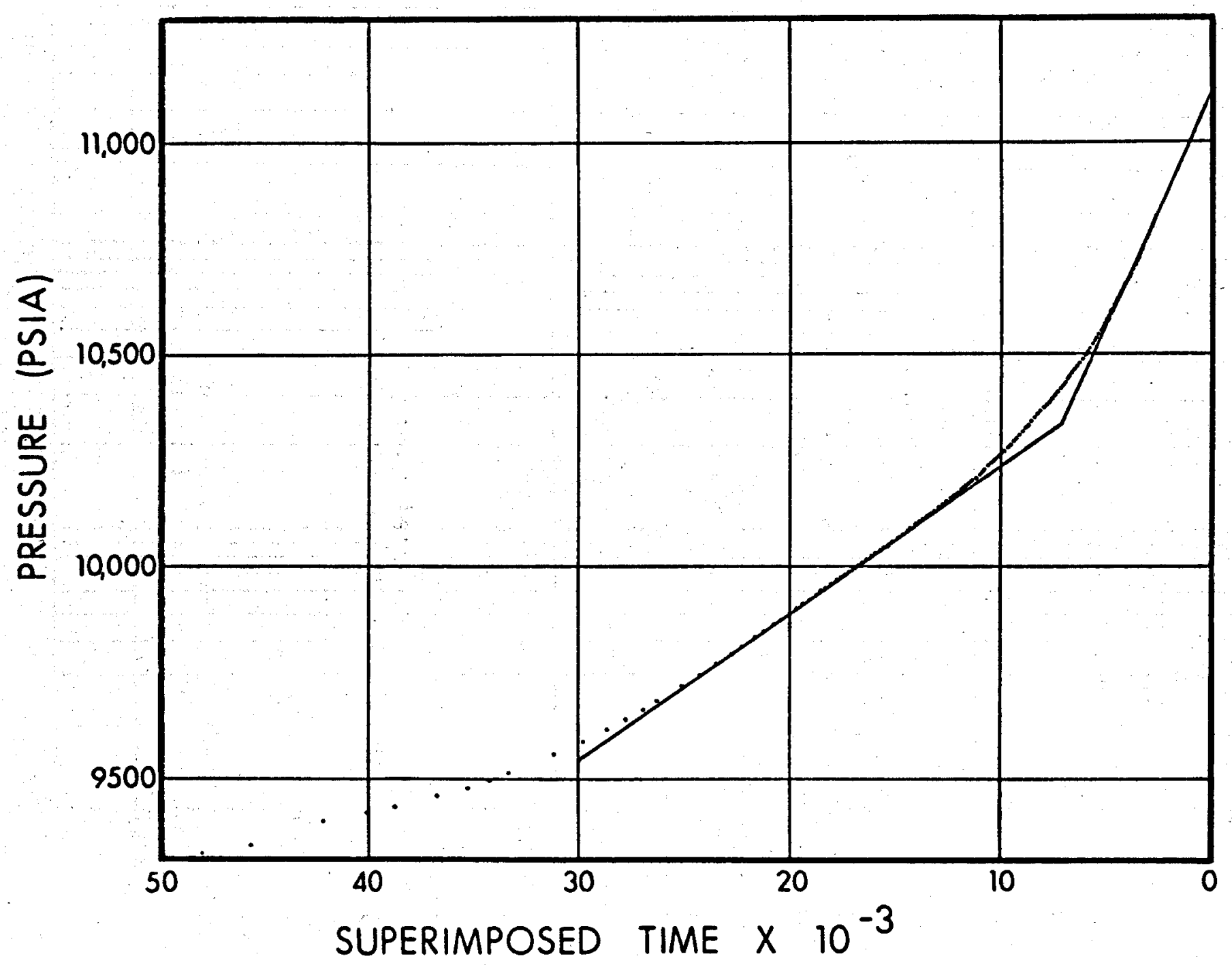


FIGURE 19

FAIRFAX FOSTER SUTTER NO.2

BOTTOMHOLE PRESSURE MINUS

SURFACE PRESSURE VS SHUT - IN TIME

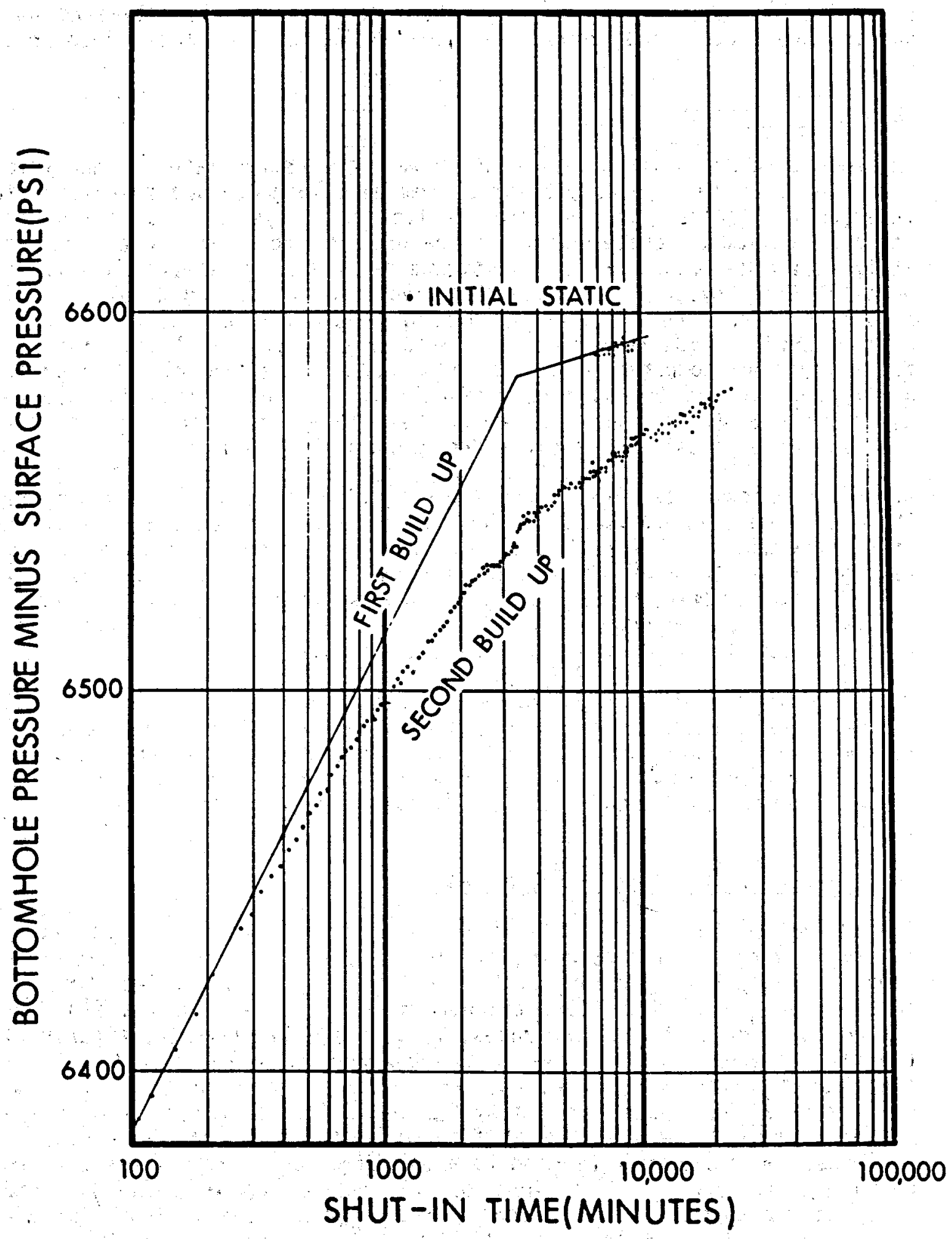


pressure data (extrapolated) were added to the buildup plot, further curvature was indicated. This could easily indicate an extrapolation to the initial pressure. Even though the final points were estimated using surface pressures, this curvature supports the parallel fault interpretation.

\section{$12.3 \quad$ Validation}

In order to check which interpretation was more appropriate, an analytical rnodel was used to compute pressures from each wedge-shaped reservoir (two intersecting faults) and from the parallel fault system. Using a minimum standard deviation criterion as a measure of the goodness of fit, the analytical model was used to investigate several wedge shapes as well as a parallel fault system. The best fits resulted from using parallel faults 1764 feet apart with the well equidistant from both, and with two faults, each of which is 882 feet from the well, intersecting at $120^{\circ}$. The minimum deviations computed for these two cases indicated almost identical quality of fit and it. would be difficult to make an engineering judgment as to which reservoir shape is most likely to exist. The input data and the results of these computations are given in Volume 11 .

After the analysis was completed, new geological information was obtained. These data were filed in Docket No. 79-298 with the Louisiana Department of Conservation by Franks Petroleum, Inc. One document presented was a geological map showing two parallel faults about 1900 feet apart with the Neuhoff No. 2 well approximately midway between the faults (when the faults are migrated to the $M-6$ level). This geological interpretation fits the parallel fault model hypothesized above.

On the basis of this new geological information, and using the Universjty of Texas compressibility data which agree with those of Swanson 10 . it would seem that the parallel fault interpretation is consistent with the geologic environment. The skin effect in this case is still-1.97, since it does not depend upon the areal configuration of the drainage pattern.

\subsection{Analysis of Second Drawdown Test}

The 11-day drawdown test data were interpreted assuming a wedge-shaped reservoir with two intersecting faults (Fig. 20). This analys is gave a good straight line for the latter portion of the test, but the early portion could not be analyzed because of uncertainties in the flow rates during the period of changing rates; $i . e$. , there was severe scattering for the first several hours of the test. However, the latter portion of the test corresponded with transient flow theory by demonstrating a well defined straight line predicted by Eq. D-1. The slope of this line was 0.1085 , and since this period of flow was effective during the time that the pressure disturbance reached both barriers, the analys is was performed using a flow fraction equivalent to 0.313 of a circle $\left(112.7^{\circ}\right)$. Under this interpretation the formation is estimated to have a $\mathrm{Kh}$ of $852 \mathrm{md}-\mathrm{ft}$ and a permeability of $14.7 \mathrm{md}$. No attempt was made to compute the skin factor because the straight line had been translated, owing to the presence of the linear barriers, and produced a false intercept. 
FIGURE 20

FAIRFAX FOSTER SUTTER NO.2

$\triangle p_{n} / q_{n}$ VS SUPERIMPOSED TIME

FOR SECOND DRAWDOWN $\mathrm{p} *=11,147$ PSIA

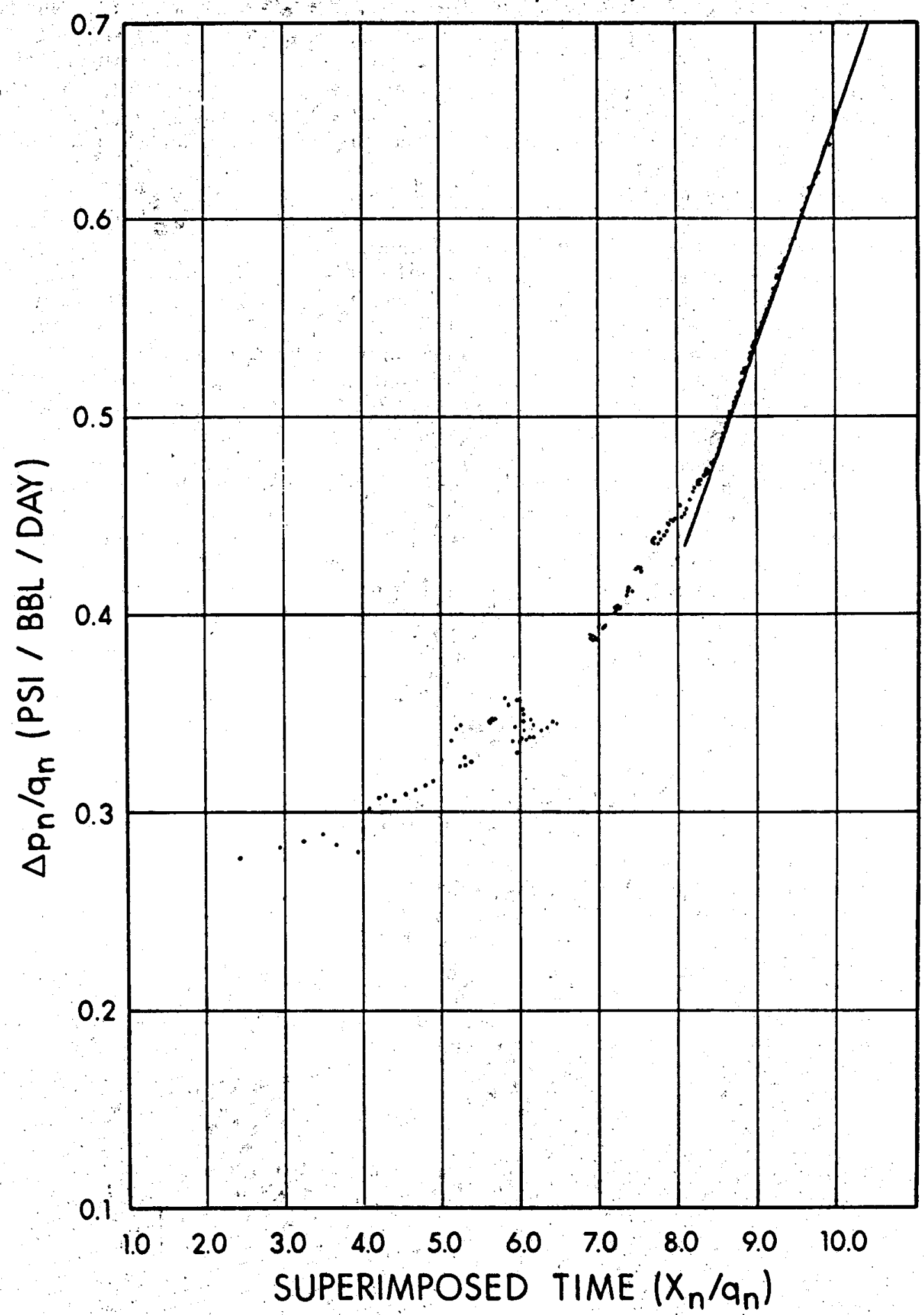




\subsubsection{Effect of Original Pressure}

The first portion of the analysis was made assuming the wedge-shaped reservoir of two intersecting faults, which extrapolated to an original pressure of 11,146 psia. If a system of two parallel faults is assumed, an original pressure of 11,300 psia should be used to compute the plotting functions for Eq. D-18. This analys is was made, and, al though the straight-line portion of the curve was translated to accommodate the higher original pressure, there was no significant change in the slope.

\subsection{Analysis of First Buildup Data}

The buildup curve following the 72-hour flow test was based upon surface pressures extrapolated to bottomhole conditions, using data obtained during the second buildup plus a limited amount of data (the last 38 hours) obtained from the HP gauge at the end of the buildup period. Figure 19 is a plot of the difference in pressure between the surface deadweight tester (DWT) and the HP gauge as a function of time during the second buildup. The points can be closely approximated by two straight lines. The actual difference is attributable to thermal effects in the wellbore as heat is lost by conduction to surrounding formations and by convection as the heavier cooler water descends through the lighter hotter water. The points obtained during the first buildup are substantially higher ( 30 psi) than those of the second. Intuitively this appears reasonable, since the formation surrounding the wellbore is hotter and the rate of heat loss lower after the longer flow period. The curves were arbitrarily drawn to converge at 100 minutes, since surface temperatures of the flowing fluids were approximately the same in both cases.

The pressure difference as a function of time was found from the graph and added to the measured DWT pressures obtained during the first buildup.

The extrapolated bottomhole pressures were plotted against the superimposed rate/time function (Fig. 21) and the resulting curves interpreted using Eq. D-24. Only one interpretable straight line resulted, the slope of which gave a flow capacity of $805 \mathrm{md}-\mathrm{ft}$ and a permeability of $13.9 \mathrm{md}$. Equation $D-29$ was used to compute the distance to the nearest boundary, which was found to be 926 feet. This is in substantial agreement with the results of the second buildup when using a system compressibility of $4 \times 10^{-6} \mathrm{rol} / \mathrm{vol} / \mathrm{psi}$.

The latter portion of the buildup could not be interpreted because a leak occurred while retrieving the Amerada RPG-3 gauges. This unknown production distorted the buildup curve.

A summary of the results of the analyses of all the test data is given in Table 3. No attempt was made to estimate the volume of water contained in the aquifer because the drawdown and buildup data show no evidence that al1 the limits of the aquifer have been reached during testing. 
FIGURE 21

FAIRFAX FOSTER SUTTER N0.2

SUPERIMPOSED RATE - TIME

BUILD UP NO.I

g

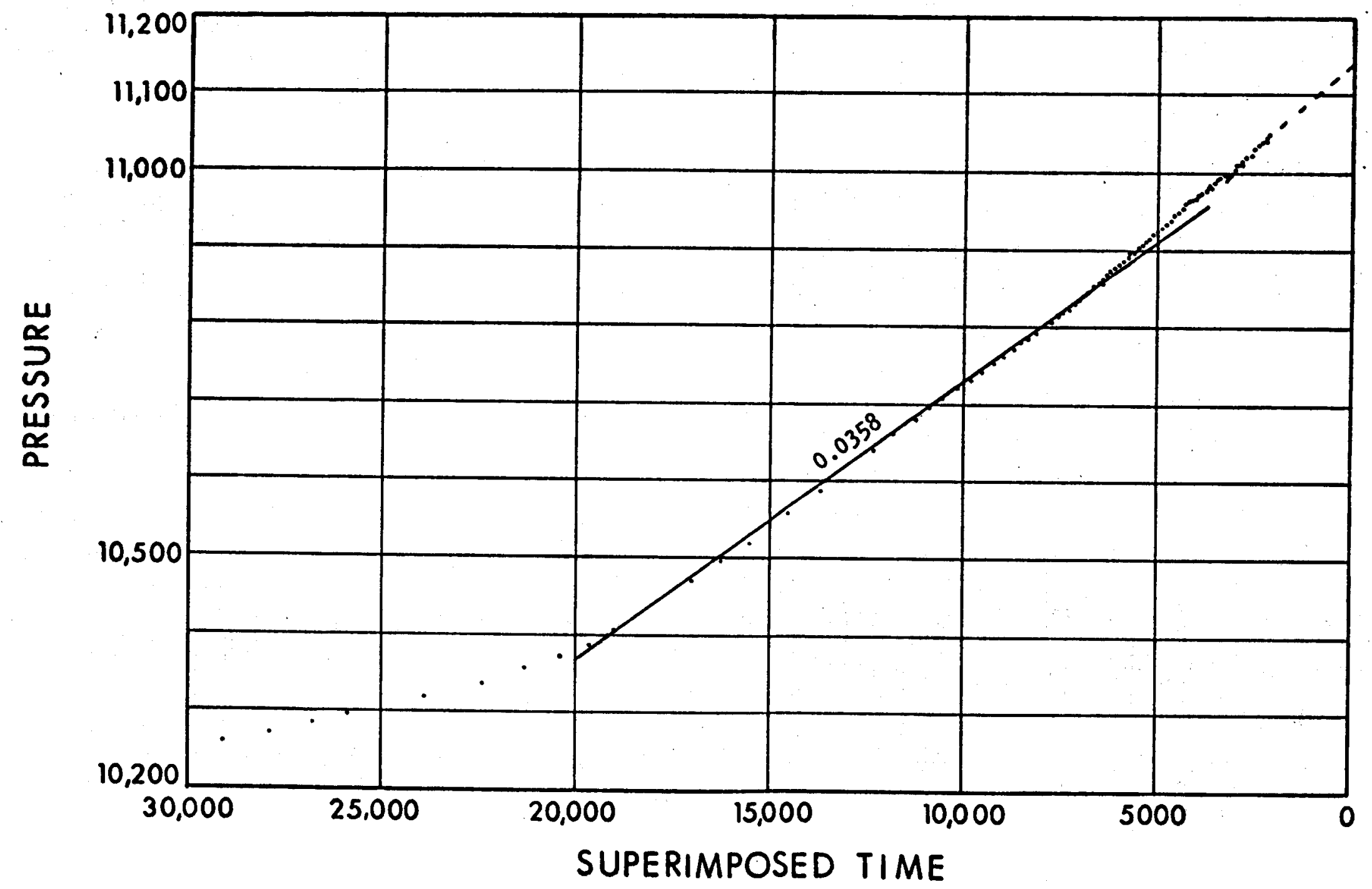

C 
TABLE 3

\section{SUMMARY OF RESULTS OF RESERVOIR ANALYSIS}

\begin{tabular}{|c|c|c|c|c|c|c|c|}
\hline TEST & $\begin{array}{l}\frac{\text { SLOPE }}{\text { First Second }} \\
\text { st. line st. line }\end{array}$ & $\begin{array}{c}K_{h} \\
(m d-f t)\end{array}$ & $\begin{array}{c}K \\
\text { (md) }\end{array}$ & $\begin{array}{l}\text { Skin } \\
\text { Effect }\end{array}$ & $\begin{array}{c}\text { Distance } \\
\text { to } \\
\text { Barrier } \\
(\mathrm{ft}) \\
\end{array}$ & $\begin{array}{l}\text { Initial } \\
\text { Pressure } \\
\text { at Datum } \\
\text { (psia) } \\
\end{array}$ & $\begin{array}{l}\text { Angle of } \\
\text { Intersect- } \\
\text { ing Faults }\end{array}$ \\
\hline First buildup & 0.03596 & 805 & 13.9 & -2.42 & 926 & 12,084 & - \\
\hline Flow test & 0.1085 & 852 & 14.7 & - & - & - & - \\
\hline Second buildup & $0.03499 \quad 0.1119$ & 827 & 14.3 & -1.97 & $\left\{\begin{array}{l}881 \\
934\end{array}\right\} *$ & 12,089 & $112.7^{\circ}$ \\
\hline
\end{tabular}

\section{ANALYTICAL MODELS OF}

SECOND BUILDUP

$120^{\circ}$ wedge
Parallel faults

$\begin{array}{ll}0.03499 & 0.1119 \\ 0.3499 & 0.1119\end{array}$

827
827

$14.3-1.97$

$881 t$
$\left\{\begin{array}{l}839 \\ 931\end{array}\right\}$

12,089

$120^{\circ}$

*Computed by two different methods.

+Two intersecting faults equally spaced from well. IDistance to each fault. 
12.6 Attempt to Compute Aquifer Volume

The pressure data from the sefond buildup test were analyzed using a technique presented by Prasad,23 in an attempt to determine the volume of water contained in the aquifer. Basically the method involves a heuristic search to determine the combination of aquifer area and distance to the nearest boundary that minimizes the mean squared error between the calculated and observed pressures. The behavioral equation used to calculate pressures assumes that all the limits of the reservoir have been affected by the pressure disturbance originating at the well prior to shut-in. The minimum value of the mean squared error term was obtained with a drainage area of 1883 acres and a distance to the closest linear boundary of 866 feet. This distance agrees favorably with that computed using both the wedge and parallel fault models, i.e., 882 feet. The mean squared error for this configuration, however, was nearly eight times higher than that for either the intersecting fault or parallel fault case. Since the latter two cases assume that the aquifer is unbounded in at least one dimension, it can be concluded that the full limits of the aquifer can not be identified with such a short flow test.

\subsection{Termination of the Flow and Buildup Tests}

The HP gauge malfunctioned at 7:40 a.m. on July 5, 1979, and the subsurface signal could not be re-acquired. An attempt was made to pull the subsurface assembly, but the wireline jammed in the restrictive areas of the flow tubes of the grease injector head on the stuffing box. It was found later that the cause of the stuck wireline was buildup of scale on the single-conductor cable.

An attempt was made to free the wireline by injecting acid through the lubricator. This failed, and it became necessary to kill the well in order to remove the lubricator and retrieve the pressure gauge.

The well was killed with a $16.8 \mathrm{lb} / \mathrm{gal}$ oil-base mud pumped through the tubing to a depth of 13,800 feet. The wireline blowout preventers were closed, the lubricator was removed, and a wireline clamp was installed above the blowout preventers. Scale on the wireline was approximately $1 / 8$ inch thick at the top, decreasing in thickness over the first 4000 feet of wireline pulled. The line was so badly scaled that it required partial cleaning prior to entering the odometer before being spooled. After the wireline and the bottomhole assembly were recovered, the well was secured in a shut-in condition to await orders for future activity.

It was determined that the cause of the final gauge failure was a short in the single-conductor cable; the Hewlett-Packard quartz crystal gauge that was in the well for more than 27 days worked successfully when tested in the laboratory. 
Results of all analyses are given in Volume II of this report.

\subsubsection{Chemical Analysis of Gas}

Seven gas samples and 20 water samples were taken for chemical analysis. All but one of the gas samples were taken during the 72-hour flow test. The results of the analyses were so consistent that it was considered unnecessary to continue frequent gas analyses. During the 10-day test only one gas analysis was obtained; it confirmed that the decision to. discontinue the gas analyses was correct.

The gas stream was tested periodically for $\mathrm{H}_{2} \mathrm{~S}$, and during the first day of the 72-hour test the results showed 4 to $5 \mathrm{ppm}$ of $\mathrm{H}_{2} \mathrm{~S}$ in the gas stream. On the second day of the test the $\mathrm{H}_{2} \mathrm{~S}$ level increased to 6 to 7 $\mathrm{ppm}$ and remained in this range throughout the duration of the flow tests.

The gas also contained approximately $8 \mathrm{~mol}$ percent of $\mathrm{CO}_{2}$ - Undoubtedly the presence of $\mathrm{CO}_{2}$ plus considerable dissolved calcium and magnesium carbonate was the cause of the severe scaling problems in the production equipment.

One sample of separator gas was analyzed for radon under the direction of Dr. Thomas F. Kraemer, U.S. Geological Survey, and Dr. David F. Reid, Naval Ocean Research and Development Activity, at the National Space Technology Laboratories in Bay St. Louis, Mississippi. A summary of the gas analys is is shown in Table 4.

\subsubsection{Chemical Analysis of Water}

The water analyses were also consistent, and it is difficult to attribute any variations in the analyses to changes in the properties of the produced water. There are no well established trends of change in any constituent, and the differences must be considered random sample variations. The properties that did show changes were the conductivity, which dropped abruptiy between the first and second flow tests, and the $\mathrm{pH}$, which increased at the same time.

A summary of the analysis of the water is shown in Table 5. Although the cation and anion concentrations balance within one percent, the sum of the concentrations of the materials identified is nearly 30,000 parts per million less than the measured value of the total dissolved solids. The reason for this discrepency has not been identified. An attempt should be made on all future tests to identify the cause of this error should such occur.

Several water samples were collected by members of the chemistry department at McNeese State University and analyzed in their laboratory. The ion concentrations (see Table 6) agree favorably with those obtained by Southern Petroleum Labs on site; however; McNeese's results show closer agreement between total dissolved solids and the sum of individual ion concentrations. 
TABLE 4

CHEMICAL ANALYSIS OF GAS

(7 samples)

\begin{tabular}{lcc} 
Constituent & $\begin{array}{c}\text { Mol } \\
\text { Percent }\end{array}$ & $\begin{array}{c}\text { Standard } \\
\text { Deviation }\end{array}$ \\
\hline Nitrogen $\left(\mathrm{N}_{2}\right)$ & 0.518 & 0.017 \\
Carbon dioxide $\left(\mathrm{CO}_{2}\right)$ & 7.85 & 0.22 \\
Methane $\left(\mathrm{CH}_{4}\right)$ & 89.57 & 0.20 \\
Ethane $\left(\mathrm{C}_{2} \mathrm{H}_{6}\right)$ & 1.78 & 0.03 \\
Propane $\left(\mathrm{C}_{3} \mathrm{H}_{8}\right)$ & 0.20 & 0.003 \\
Isobutane $\left(\mathrm{C}_{4} \mathrm{H}_{10}\right)$ & 0.061 & 0.004 \\
n-Butane $\left(\mathrm{C}_{4} \mathrm{H}_{10}\right)$ & 0.014 & 0.005 \\
Hydrogen sulfide $\left(\mathrm{H}_{2} \mathrm{~S}\right)$ & $4-5$ ppm first day \\
& $6-7$ ppm remainder of test \\
Radon (corrected to & 238 picocuries per liter \\
time of sampling) &
\end{tabular}


TABLE 5

CHEMICAL ANALYSIS OF PRODUCED WATER

(20 Samples)

Constituent

Total dissolved solids

Total solids

Calcium (hardness, as $\mathrm{CaCO}_{3}$ )

Magnesium (as $\mathrm{MgCO}_{3}$ )

Bicarbonate $\left(\mathrm{HCO}_{3}\right)$

Carbonate

Chloride (Cl)

Total iron ( $\mathrm{Fe}$ )

Sulfate $\left(\mathrm{SO}_{4}\right)$

Dissolved silicate $\left(\mathrm{SiO}_{2}\right)$

Copper (Cu)

Zinc ( $\mathrm{Zn}$ )

Boron (B)

Arsenic (As)

Chromium (Cr)

Mercury $(\mathrm{Hg})$

Lead(Pb)

Cadmium (Cd)

Sodium ( $\mathrm{Na}$ )

Potassium $(K)$

Uranium (U)

Radium ( $R a$ )

Density

pH

Sus viscosity at $95^{\circ} \mathrm{C}$
Mi 11 igrams

per liter

190,904

203,475

18,305

2,320

208

0

91,387

56

$<1$

60

0.33

2.11

68.5

0.16

$<0.0005$

0.77

48,281

988

0.00003

1,765 disintegrations per minute per liter

$1.0932 \mathrm{~g} / \mathrm{ml}$

6.18

31.3
Standard

Deviation

10,000

20,000

1,000

187

49

0

3,500

14

18

0.07

1.55

7.3

0.03

-

0.22

2,000

100 
CHEMICAL ANALYSIS OF PRODUCED WATER

(McNeese State University)

Constituent

Total dissolved solids

Chloride (Cl)

Dissolved silicate $\left(\mathrm{SiO}_{2}\right)$

Sodium $(\mathrm{Na})$

Potassium (K)

Iron (Fe)

Zinc $(Z n)$

Calcium (Ca)

Magnesium (Mg)

Cadmium (Cd)

Strontium (Sr)
Milligrams per liter

155,880

94,705

86

44,400

900

57

0.89

7,670

623

0.2

597 


\subsubsection{Chemical Analysis of Scale}

Analyses were made on samples of scale taken from the disposal well, deposits in the filter, and deposits on the wire line. All of these analyses confirmed that the scale was normal carbonate scale (Table 7 ). In pulling both wirelines that were used, sufficient difficulty was encountered to suggest the need for a bottomhole scale and corrosion inhibitor system on future wells. The slick line used in the first flow buildup tests was badly corroded and caused difficulties during the pulling operations. In fact, scale deposits and corrosion caused sufficient wear on the stuffing box to produce a leak.

The braided line used with the HP gauge also became badly corroded and encrusted with scale for at least the upper 4000 feet.

\subsubsection{PVT Analysis of the Recombined Separator Sample}

Periodically throughout the test, separator gas and liquid samples were taken for eventual recombination studies. Because the production rates were inaccurate during the early flow test, separator gas and liquid samples taken at the beginning of the second flow test were recombined in the ratio of 22.3 standard cubic of gas per separator barrel of water. The separator operating conditions at the time of sampling were 260 psig and $210^{\circ} \mathrm{F}\left(99^{\circ} \mathrm{C}\right)$.

The first time the fluids were recombined in a windowed cell, a 2-cc port at the top of the cell prevented visual observation of a gas bubble. In this type of cell bubble points are estimated by determining the pressure at which the system compressibility exhibits a sharp discontinuity. This laboratory technique proved to be unsatisfactory for these fluids because the compressibility data showed a smooth curvature with no well defined break.

The second recombination was made in a cell in which the top could be observed. Equilibrium at each pressure was established by rocking the cell for 20 to 30 minutes, when further rocking caused no change in the pressure.

Using this procedure the bubble-point pressure was taken to be the pressure at which a tiny bubble of gas could be observed. For this sample this pressure was 11,750 psia at the reservoir temperature of $270^{\circ} \mathrm{F}$ $\left(132^{\circ} \mathrm{C}\right)$. Although this is 450 psi below the original reservoir pressure, most likely the water is saturated with gas at reservoir conditions. Small errors in separator measurements, the deposition of solids in the tubing during production, and experimental techniques all could contribute to this small discrepancy. Evaluation of the nonlinear equation derived from the laboratory work of Blount et al.24 predicts that the solubility of methane at reservoir conditions would be $24.9 \mathrm{scf} / \mathrm{bbl}$.

The pressure-volume properties of this gas-water mixture are given in Tables 8 and 9 and a list of definitions is given in Table 10. 
TABLE 7

\section{ANALYSIS OF SCALE}

Constituent

Calcium carbonate

Iron carbonate

Magnesium carbonate

$0 i l$ and lubricant

Sodium chloride

Clay, drilling fluid

Other
Composition of scale, mole percent Disposal well Filter Wireline

$\begin{array}{ccc}88.0 & 2.0 & - \\ 7.8 & 5.7 & 66.5 \\ 2.1 & - & - \\ - & 24.6 & 33.5 \\ - & 14.2 & - \\ - & 53.5 & - \\ 2.1 & - & -\end{array}$


TABLE 8

RESERVOIR FLUID PROPERTIES OF WATER*

FROM FAIRFAX FOSTER SUTTER NO. 2 (Differential Liberation)

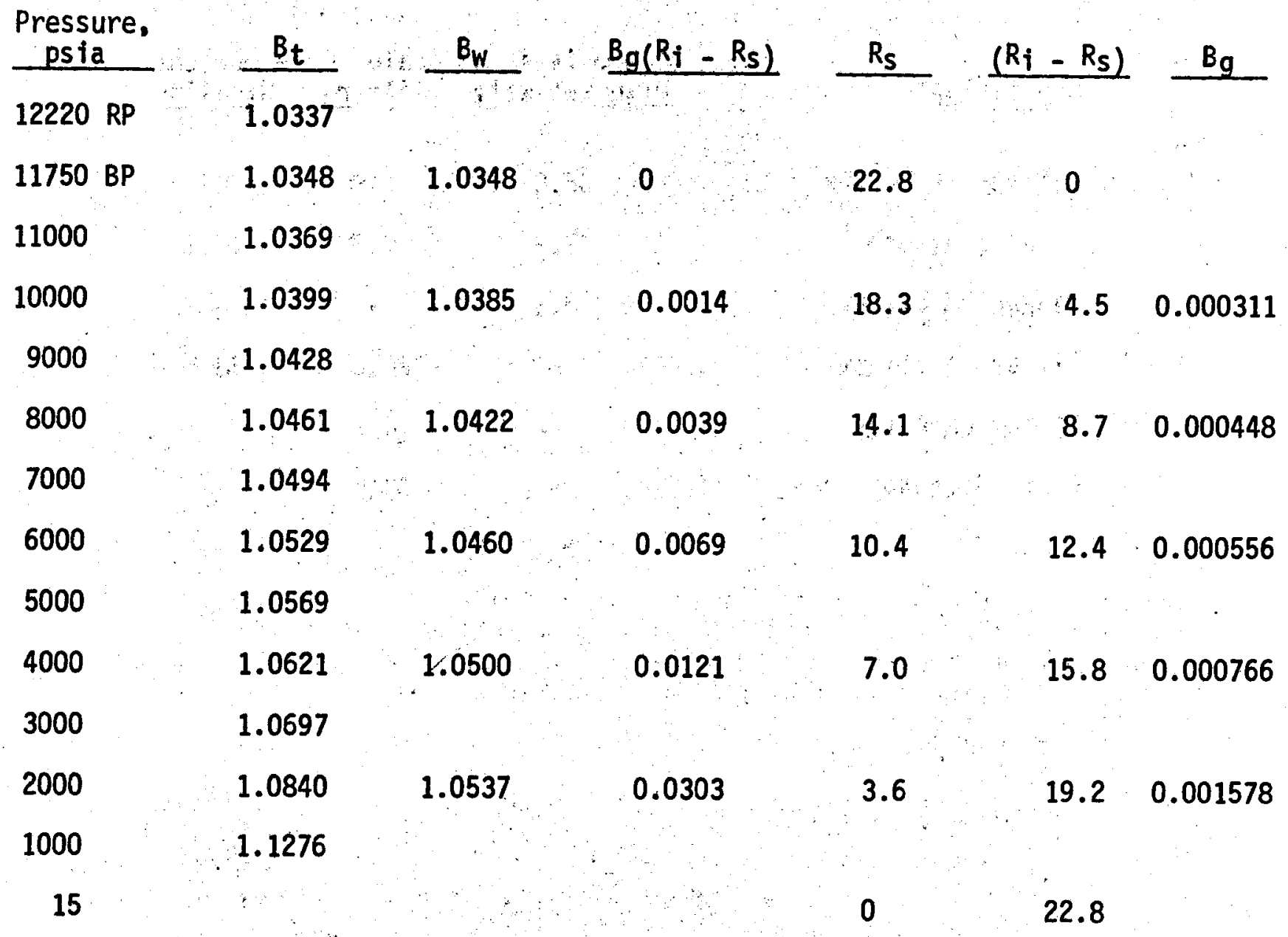

*Separator gas-water ratio $=22.3 \mathrm{scf} / \mathrm{bbl}$. 


\section{TABLE 9}

PRESSURE VOLUME RELATIONS OF WELL STREAM* AT $270^{\circ} \mathrm{F}$ (Differential Liberation)

\begin{tabular}{lll}
$\begin{array}{c}\text { Pressure, } \\
\text { psia }\end{array}$ & $\begin{array}{c}\text { Relative } \\
\text { volume } \\
\text { (v/vsat) }\end{array}$ & $\begin{array}{c}\text { Density, } \\
\text { gm/cc }\end{array}$ \\
\hline $12200 \mathrm{RP}$ & 0.9989 & 1.0758 \\
$11750 \mathrm{BP}$ & 1.0000 & 1.0746 \\
11000 & 1.0020 & 1.0725 \\
10000 & 1.0049 & 1.0694 \\
9000 & 1.0077 & 1.0694 \\
8000 & 1.0109 & 1.0630 \\
7000 & 1.0141 & 1.0598 \\
6000 & 1.0175 & 1.0562 \\
5000 & 1.0214 & 1.0521 \\
4000 & 1.0264 & 1.0470 \\
3000 & 1.0337 & 1.0396 \\
2000 & 1.0475 & 1.0259 \\
1000 & 1.0897 & 0.9862
\end{tabular}

*Separator gas-water ratio $=22.3 \mathrm{scf} / \mathrm{bb} \mathrm{l}$. 
$B_{g}=$ gas formation volume factor, bbl, in reservoir per standard cubic foot

$R_{S}=$ gas in solution, standard cubic feet per barrel

$R_{\mathbf{j}}=$ original value of gas in solution, standard cubic feet per barrel

$B_{W}=$ water formation volume factor

$B_{t}=$ two-phase formation volume factor

$$
\begin{aligned}
& B_{t}=B_{0}+\left(R_{i}-R_{5}\right) B_{g} \\
& B_{t}=B_{0} \text { at bubble-point pressure and higher pressures }
\end{aligned}
$$

$B_{i}=$ value of $B_{t}$ at original pressure

$P_{b}=$ bubble-point pressure (psia)

$P \quad=$ pressure (psia)

$B_{b}=$ water formation volume factor at bubble point

Standard conditions $=14,696$ psia and $60^{\circ} \mathrm{F}$ 


\subsection{Killing the Well}

Production testing was completed and the well was shut in for pressure buildup on June 20, 1979. A Hewlett-Packard quartz crystal pressure gauge suspended from a single-conductor electric cable recorded bottomhole pressure until it malfunctioned at $7: 40 \mathrm{a} \cdot \mathrm{m}_{\text {. }}$ on July 5 . Attempts to pull the gauge and wire line were unsuccessful with up to 2000 ib of tension applied on the line. It was concluded that scale buildup on the electric i ine fouled it within the sealing elements in the pressure lubricator, and that it would be necessary to kill the well to recover this equipment. This was deferred for 5 days to permit additional observations of pressure buildup on the deadweight test instrument.

On July 10, 1979, the well was killed by pumping one barrel of diesel oil ahead of 110 barrels of $16.8 \mathrm{lb} / \mathrm{gal}$ ofl-base mud. The initial pump-in and shut-in tubing pressure was 4000 psi. The well was dead after 102 barrels of oil-base mud had been displaced into the tubing.

The lubricator was removed from the wellhead and the Hewlett-Packard gauge and wireline were recovered. A backpressure valve was installed in the Canfield bushing in the lower portion of the wellhead.

\subsection{Operator Notification}

During the test period on the well, Neuhoff 0 il and Gas notified Gruy that they desired to resume operations on the well at the completion of Gruy's project for the purpose of testing the sand occurring from 14,840 to 14,900 feet. It was agreed that Gruy would plug off the Geo ${ }^{2}$ perforations in a manner that would establish a plugback at a total depth below 14,950 feet.

\subsection{Abandonment}

Competitive bids for a suitable workover rig were solicited and a contract was awarded to Well Tech Company. Well Tech. rigged up on August 8, 1979, after the backpressure valve in the Canfield bushing was satisfactorily pressure tested to $10,000 \mathrm{psi}$. The christmas tree was removed and BOP's installed and tested to 10,000 psi. The backpressure valve was then removed.

A pull of $265,000 \mathrm{lb}$ did not free the tubing from the packer at 15,510 feet. A Dialog wireline truck moved onto location and a 1.375-inch sinker bar was run to 13,550 feet and stopped. A trip was then made with a freepoint indicator to determine where the tubing was stuck. The status of the tubing was:

- $55 \%$ free at 7000 feet

- $65 \%$ free at 8000 feet

- $55 \%$ free at 9000 feet

- $38 \%$ free at 10,000 feet

- $0 \%$ free at 11,000 feet 
A jet cutter was run to 14,962 feet where it stopped. The tool was picked up to 14,952 feet and fired. It required 3800 psi to break circulation on the mud, and the tubing came free after some 30 barrels of mud had been circulated.

The oil-base mud in the hole was displaced with $16.1 \mathrm{lb} / \mathrm{gal}$ water-base mud furnished by Neuhoff, collected in a mud truck tank, and returned to the supplier for credit.

A pup joint was screwed into the top of the tubing and mud was circulated for 9 hours to clean the hole of contamination.

The 3-1/2 inch and 2-7/8 inch tubing were pulled and laid down. Each joint was inspected for scale and corrosion and numbered in the order of its removal from the hole. Selected samples of scale were collected for analysis. A tótal of 433 joints of 3-1/2 inch, 12.70-1b, PH6-P105 tubing were recovered. An analysis of the scale removed from the tubing by approximate depth is shown in Table 11.

Schlumberger was moved in and rigged up to run a 5-1/2 inch gauge ring and junk basket. The tools stopped at 14,712 feet. They were found to be filled with hard, dehydrated ofl-base drilling mud. Two additional attempts to get the junk basket and gauge ring to the top of the tubing fish failed because of the mud problem. It became necessary to pick up the tubing and run a bit and scraper to clean the hole to the top of the tubing fish at 14,952 feet. This was accomplished and the tubing was again laid down.

A wireline bridge plug was then set at 14,950 feet and 15 feet of cement were dump bailed on top of the bridge plug.

After BOP's were nippled down, Gruy's 10-inch 10,000-psi casinghead was removed and Neuhoff's 10-inch 5,000-psi casinghead was installed with a gate valve on top. The rig was released and all DOE materials were shipped to storage. The christmas tree was sent to WKM in New Iberia, La., for reconditioning, and the tubing was sent to Plastic Applicators for inspection and cleaning.

Neutoff 011 and Gas representatives were notified that the test well and the disposal well were officially in their custody effective at noon on August 20, 1979, in accordance with the agreement. 
Joint No. 12

Depth $\sim 360 \mathrm{ft}$

Joint No. 76

Depth $22280 \mathrm{ft}$

Joint No. 426

Depth $\sim 12,780 \mathrm{ft}$
Emission Spectrograph

Barium sulfate $\left(\mathrm{BaSO}_{4}\right)$

$42.0 \%$

Calcium carbonate $\left(\mathrm{CaCO}_{3}\right) \quad 35.0$

Iron carbonate $\left(\mathrm{FeCO}_{3}\right) \quad 2.0$

Silica $\left(\mathrm{SiO}_{2}\right)$

6.0

Manganese carbonate $\left(\mathrm{MnCO}_{3}\right) 0.6$

$85.6 \%$

X-ray Diffraction

Barium sulfate

Calcium carbonate

Silica

major

major

major

(major: >10\%; minor: 1-10\%)

Emission Spectrograph

Barium sulfate

Cálcium carbonate

Iron carbonate

Silica

Manganese carbonate

$58.0 \%$

20.0

1.0

4.0

0.4

$83.4 \%$

X-ray Diffraction

Barium sulfate

Calcium carbonate

Silica

Illite

Kaolinite

major

major

minor

minor

minor

Emission Spectrograph

Barium sulfate

Calcium carbonate

Iron carbonate

Silica

Manganese carbonate

$31.0 \%$

30.0

21.0

11.0

2.0

$95.0 \%$

X-ray Diffraction

Barium sulfate

Calcium carbonate

major

major

Iron carbonate 


\section{$14.0 \quad$ CONCLUSIONS}

The successful completion of the test on the Fairfax Foster Sutter No. 2 well contributed a significant amount of interesting and important information concerning the producing behavior of geopressured-geothermal aquifers. This test constituted the deepest known production test of this potential resource in the United States in which no known free hydrocarbon saturation was present nearby. The results of this and subsequent tests will provide the framework for assessing the commercial potential of geopressured geothermal energy.

More specifically, the following characteristics of the reservoir rock and its contained fluids were determined:

1. The average dissolved gas content of the produced brine was 22.8 standard cubic feet per stock tank barrel of water. Recombination studies of the separator gas and liquid samples confirmed that the water was saturated with gas at the original reservoir pressure $(12,220 \mathrm{psia})$ and temperature $\left(270^{\circ} \mathrm{F}\right)$.

2. The gas-water ratio remained constant throughout the test and was unaffected by changes in operating conditions or pressure drawdown.

3. The chemical composition of the produced water remained essentially constant throughout the test. There were no observable trends in the chemical analyses of any components and all variations appeared to result from either random experimental errors or sampling difficulties.

4. The total dissolved solids content of the brine averaged 190,904 $\mathrm{mg} / \mathrm{liter}$ and the salinity (expressed in terms of equivalent $\mathrm{NaCl}$ concentration) was $160,000 \mathrm{mg} / \mathrm{liter}$.

5. The gas stream withdrawn from the separator consisted mostly of methane (89.57 mol percent) and $\mathrm{CO}_{2}$ (7.85 mol percent). The specific gravity of the gas was 0.6447 (air = 1) and the energy content of the dry gas was 948 Btu/cu ft.

6. The MA-6 sand tested in this well has 272 net feet of sand, 58 feet of which was opened to flow. The effective porosity of the sand is 19.3 percent and the average permeability, estimated from the drawdown and buildup data, is $14 \mathrm{md}$.

7. On the basis of a detailed analysis of the pressure drawdown and buildup data, it was possible to identify two reservoir boundaries. One interpretation of the data suggested that the well was contained between two linear discontinuities intersecting at approximately $120^{\circ}$. A second interpretation indicated that the well was nearly midway between two parallel faults approximately 1800 feet apart. The latter finding is consistent with the geological interpretation for the area. 
8. The high concentration of calcium and magnesium salts in the produced fluid resulted in severe scale deposition in both surface and subsurface equipment. This will present a serious problem in future $\mathrm{GeO}^{2}$ tests unless it is prevented by injecting conventional high-temperature scale inhibitors at the bottom of the producing tubing.

9. Similarly, the presence of nearly 8 percent $\mathrm{CO}_{2}$ in the dissolved gas produces a corrosive fluid, particularly at geotemperatures. This corrosion can be controlled by the injection of commercial corrosion inhibitors.

10. The short-term injection of hot water into the shallow Miocene disposal sand neither enhanced nor reduced the injectivity behavior of the well. The thermal expansion of the tubular goods in the well was minimal and the casing-cement bond was unaffected by the hotter fluid.

11. The maximum flow rate measured from the well was approximately $7747 \mathrm{~B} / \mathrm{D}$. Because of the low permeability of the reservoir, the well was incapable of sustaining this rate. 
1. National Energy PI an I1, second National Energy PIan (1979), p. I-16.

2. Ibid, p. VI-16.

3. Ibid, p. VI-18.

4. Wallace, R. H., Jr., Kraemer, T. F., Taylor, Ro E., and Wesselman, J. B., U.S. Geological Survey Circular 790, (1978) p. 144.

5. Papadapulos, S. S., Wallace, R. H., Jr., Wesselman, J. B., and Taylor, R. E.: "1975 Assessment of Onshore Geopressured-Geothermal Resources in the Northern Gulf of Mexico," Assessment of Geothermal Resources of the United States - 1975, U.S. Geological Survey Circular 726, White, D. E., and Williams, D. L., eds., pp. 125-146.

6. Stearns, R. T., "Request for Proposals (RFP) EY-77-R-08-0008 to Investigate and Evaluate Geothermal-Geopressured Wel 1s," United States Energy Research and Development Administration (April 1977).

7. Prasad, R. K., "Pressure Transient Analysis in the Presence of Two Intersecting Boundaries," Journal of Petroleum Technology, Jan. 1975, pp. 89-96.

8. Tiab, D., and Kumar, A., "Detection and Location of Two Parallel Sealing Faults Around a Well," paper No. SPE 6056, Presented at the 51st Annual Fall Meeting of SPE, New Orleans, La. (Oct. 1976).

9. Gray, K. E., private communication.

10. Swanson, B. F., "Compressibility of Geopressured Reservoirs," paper No. SPE 8036.

11. Theis, C. V., "The Relationship Between the Lowering of Piezometric Surface and Rate and Duration of Discharge of Wells Using Ground-Water Storage," Irans. AGU (1935), Vol. 2, p. 519.

12. Collins, R. E., Flow of Fluids Through Porous Materials, The Petroleum Publishing Co., Tulsa (1976).

13. Muskat, M., Flow of Homogeneous Fluids Through Porous Media, J. W. Edwards, Inc., Ann Arbor, Mich.

14. Matthews, C. S., and Russel1, D. G., Pressure Build Up and Flow Tests in Wells, Vol. I, SPE Monograph (1967).

15. Horner, D. R., "Pressure Build Up in Wells," Proc., Third World Petroleum Congress, Vol. II (1951), p. 503. 
16. Miller, C. C., Dyes, A. B., and Hutchinson, C. A., Jr., "The Estimation of Permeability and Reservoir Pressure from Bottom-Hole Pressure Build Up Characteristics," Trans. AIME (1950) Vol. 189, pp. 91-106.

17. Earlougher, R. C., Jr, Advances in Well Test Analysis, Vol. 5, SPE Monograph (1977).

18. Ramey, H. J., Jr., and Cobb, W. M., "A General Pressure Buildup Theory for a Well in a Closed Drainage Area," Journal of Petroleum Technology, Dec. 1971, pp. 1493-1501.

19. Matthews, C. S., "Analysis of Pressure Buildup and Flow Test Data," Journal of Petroleum Technology, Sept. 1961, pp. 862-870.

20. Rowan, G., and Clegg, M. W., "An Approximate Method for Transient Radial Flow," Society of Petroleum Engineers Journal, Sept. 1962, pp. 225-257.

21. Van Everdingen, A. F., and Hurst, W., "Application of the Laplace Transformation to Flow Problems in Reservoirs," Trans. AIME (1949) Vol. 186, pp. 305-324.

22. Van Everdingen, A. F., "The Skin Effect and Its Influence on the Productive Capacity of a Well," Trans. AIME (1953), Vol. 198, pp. 171-176.

23. Prasad, R. K., "A New Approach to the Analysis of Pressure Build-Up Tests in Bounded Reservoirs," to be published.

24. Blount, C. W., Price, L. C., Wenger, L. M., and Tarullo, M., "Methane Solubility in Aqueous $\mathrm{NaCl}$ Solutions at Elevated Temperatures and Pressures," Progress Report, August 1, 1979, DOE Grant No. ET-78-S07-1716. 
TO:

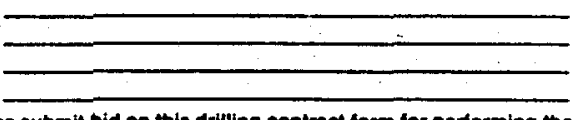

Please submit bid on this drilling contract form for performing the work outlined below, upon the terms and for the consideration set forth, with the understanding that if the bid is accepled by

this instrument will constitute s contract between us. Your bid should be mailed or delivered nol later than P.M. on .18 to the lollowing address:

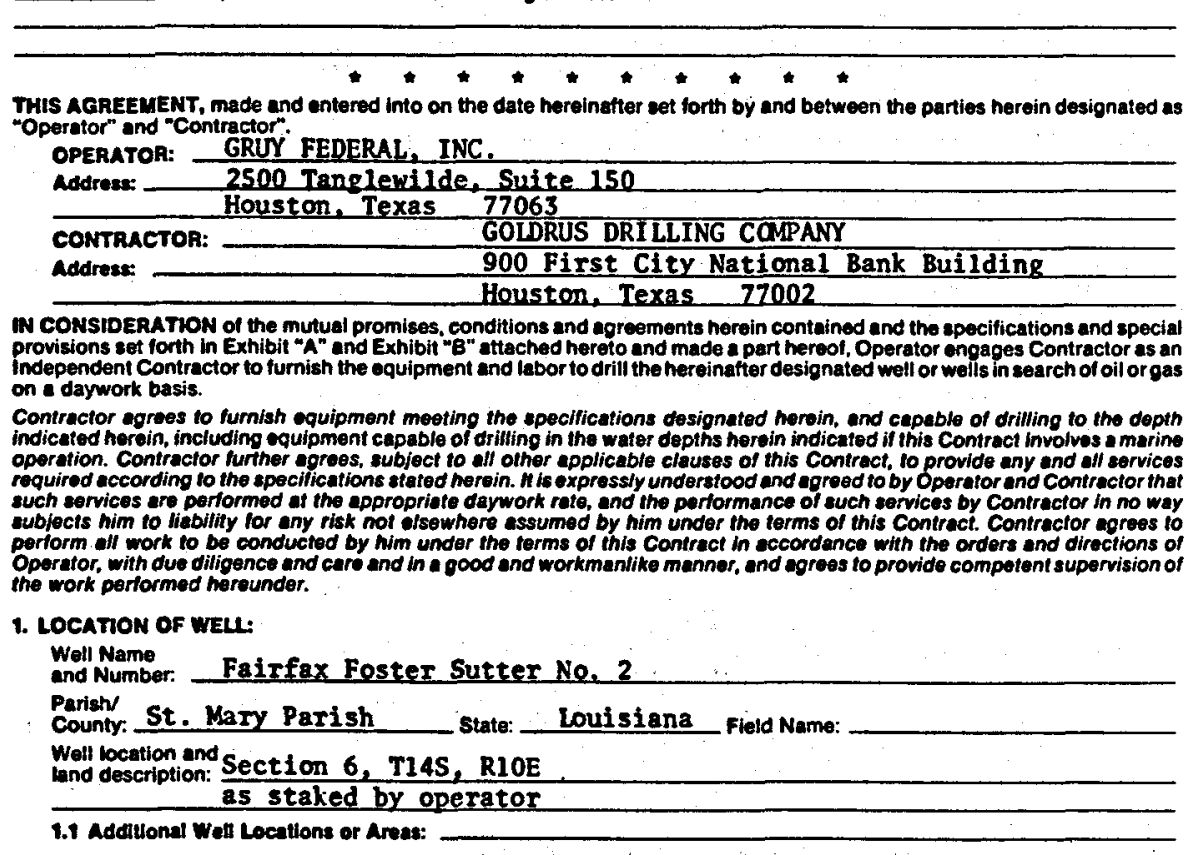

1.1 Adduonat Welt Locations or Areas:

Locations described above are for well and contract Identification only and Contractor assumes no liability whatsoever for a proper survey or location stake on Operator's lease.

2. COMMENCEMENT DATE:

Contractor agrees to use best efforts to commence operations lor the drilling of well by the day of 18

3. DEPTH:

21 Well Depth: The well (s) shall be drilled to depth of approximately _ NA

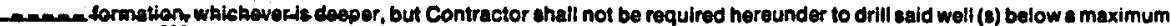
depth of NA feat, unless Contractor and Operator mutually agree to drill to a greater depth.

4. DATUORK RATES:

Contractor shall be paid at the following retes for the work performed hereunder.

4.1 Hoblization: Operator shall pay Contractor a mobjlization tee of 8 NA the well site ready, to spud. Mobilization ahall include:

4.2 Demobltzation: Operator ghall pay Contractor a demobilization fee of \$ N NA_ N or demobilization day rate during tear down of $\$$ NA_ per 24 hour day, provided however that no demobilization fee shall be payable if the contract is terminated due to the total loss or destruction of the rig. Demobilization shall include: NA

4.3 Moving ate: During the time the nig is in transit to or Irom a drill slte, or between drill sites, commencing on - Operator shall pay Contractor a sum of $\$$ NA per twenty-four (24) hour dey. 44 Operating Day Rate: for work performed per twenty-four (24) hour day with 5 operating day rate thall be:

From Depth Intervats

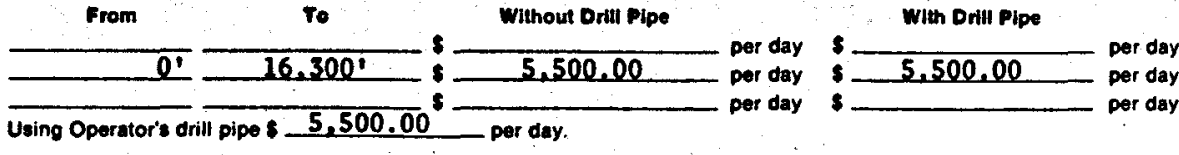

(Denwork Conirect - Page 1) 
If under the above column "With Drill Pipe" no day rates are specitied, the daywork rate per twenty-four hour day when drill pipe is in use thall be the applicable daywork rate specified in the column "Without Drill Pipe" plus compensation for any drill pipe actually used at the rates specified below; computed on the basis of the maximum drill pipe in use at any time during each twenty-four hour day.

OAIL PIPE RATES PER 24-HOUR DAY

Straight Hole

size

Grade Directlonat or

$s$ per ft. Uncontroliable Deviated Hole size Grede per it. 5 0.0625 Per $n$ $4 \frac{1}{2}-E$

Drill pipe shall be considered in use not only when in actual use but also while it is being picked up or laid down. When drill pipe is standing in the derrick it shall not be consjdered in use provided however that if Contractor turnishes special strings of drill pipe, drill collar and handling tools as provided for in Exhibit "A", the same shall be considered in use at all times when on location or until released by Operator. In no event shall fractions of an hour be considered in computing the amount of time drill pipe is in use but such time shall be computed to the nearest hour, with thirty minutes or more being considered a full hour end less than thirty minutes not to be counted.

Operating rate will begin when the drilling unit is rigged up at the drilling location, or positioned over the location during marine work, and ready to commence operations: and will cesse when the rig is ready to be moved off the location.

4.5 Repair Rate: in the event it is necessary to shut down Contractor's rig for repairs, oxcluding routine rig servicing. while Contractor is performing daywork hereunder, Contractor shall be allowed compensation as the applicable daywork rate for each period of shutdown time up to a maximum of 4 . hours for any one repair job and a total of . 24 hours for each thirty (30) day period. Thereatter, Contractor shall be compensated at a rate of $\$$ NA Der twenty-four (24) hour day.

shall not be included in computing the number of hours of shutdown time.

4.6 sundby Ttme Rate with Crews: \$_ \$,500.00 per twenty-four (24) hour day. Standby time shall be defined to include time when the rig is shut down although in readiness to begin or resume operations but Contractor is waiting on orders of Operator or on materials, eervices or other items to be furnished by Operator.

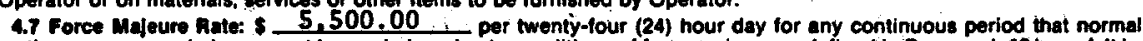
operations are suspended or cannot be carried on due to conditions of force majeure es defined in Paragraph 16 hereof. It is. hower. Understood that Operator can release the nig ln accordance whth

48 Reimbursable Coste: Operator shall reimburse Contractor for the costs ol material, equipment, work or services which are to be lurnished by Operator as provided for herein but which for convenience are actually furnished by Contractor at Operator's request, plus NA percent for such cost of handling

4. Revisjon in Rates: The rates and/or payments herein set forth due to Contractor from Operator thatl be revised to reflect the change in costs $i f$ the costs of any of the hems hereinatter listed shall vary by more than__. TWO. _ percent from the costs thereol on the date of this Contract or by the same percent after the date of any revision purauant to this paragraph:

(a) Labor costs, including all benefits, of Contractor's personnel

(b) Contractor's cost of insurance premlums:

(c) Contractor's cost of fuel, the cost per gallon/MCF being

applicable;

Cocrease the number of Contractor's personnel:

(i) Contractor's cost of spar parts ind supplies with the understanding that such spare parts and supplies constitute 35. percent of the Operating Rate and that the parties shail use the U. S. Bureau of Labor Statistics Oillield Drilling Machinery and Equipment Wholesale Price index (Code No. 1191-02) to deter mine to what extent a price variance has occurred in said spare parts and supplies.

(g) If there is any change in legislation or regulations in the area in which Contractor is working or other unforeseen, unusuat event that alters Contractor's financial burden.

\section{TIME OF PAYMENT:}

Subject to Operator's right to require that Contractor furnish him with satisfactory evidence that Contractor has paid all labor and material claims chargeable to Contractor; payment becomes due by Operator to Contractor as follows:

5.1 Payment for mobilization, drilling and other work performed at applicable day rates, and all other applicable charges shall be due upon acceptance by Operator of the work performed in accordance with this Contract, upon presentation of invoice therefor upon completion of mobilization, completion of the well, or at the end of the month in which such work was pertormed unless Operator does hereby designate that wuch invoices shall be mailed as follows:

I2 Any sum or sums not pald within 30 days after the date of invoice shall bear interest at the rate of 10 percent per annum _or the maximum legal rate. whichever is less, from such date until paid.

c.3 Attorney's Fees: II this Contract is placed in the hands of an attomey for collection of any sums due hereunder, or suit is brought on zame, or sums due hereunder are collected through bankruptcy or probate proceedings, then Operator agrees that there shall be added to the amount due reasonable attorney's loes and costs.

6. TERM:

61 Duration of Contract. This Contract shall remain in full force and offect until driling operations are completed on the

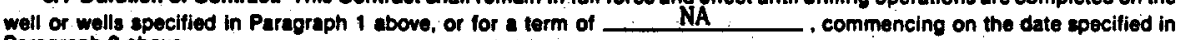
Paragrapt 2 above.

C.2 Extension of Tom: Operator may extend the term of this Contract for $\frac{0}{0}$ well (s) or lor $\geq$ period of NA by oiving notice to Contractor at least NA days prior to completion of the well then being drilied or by

Q.3 Earty Termination:

(a) By Elthet Party: Upon giving of written notice, either party may terminate this Contract when conditions of force majeure, total loss or destruction of the rig, or a major breakdown with indefinite repair time necessitate stopping operations hereunder.

(b) Ey Operator: Notwithstanding the provisions of Paragraph 3 with respect to the depth to be drilled, Operator shall have the right to direct the stoppage of the work to be performed by Contractor hereunder at any time prior to reaching the secified depth, and even though Contractor has made no defeutt hereunder. In such event Operator ahall reimburse Contractor set forth in sub-paragraph 6.4 hereot.

(c) Ey Contractor. Notwithstanding the provision of Paragraph 3 with respect to the depth to be drilled, in the went Operator shall become insolvent, or be adjudicated a bankrupt. or file, by way of petition or answer, a deblor's petition or other pleading seeking adjustment of Operator's debts, under any bankiruptcy or debtor's relief laws now or hereafter prevailing. or if any such be filed against Operator, or in case receiver be appointed of Operator or Operator's property, or any part thereol, or Operator's affairs be placed in the hands of Creditor's Committee, Contractor may, at his option elect to terminate further performance of any work under this Contract and Contractor's right to compensation shall be as set forth in subparagraph 6.4 hereol. in addition to Contractor s right to terminate periormance hereunder, Operator hereby expressly aprees to protect. indemnify and save Contractor harmless from any claims, demands and causes of action, including all costs of defense, in favor of Operator. Operator's joint venturers, or other panties arising out of any drilling commitments or obligations contained in any lease. tarmout agreernent or other agreement. which may be aflected by such termination of performance hereunder.

(d) See Gruy Federal, Inc., General Provision No. 29, "Termination for DeFault or Convenienceaywork Contract - Page 2) of the Government." 
Revised Dec. 1975

C4 (c) If euch termination occure prior to the epudding of the well, Operator thall pay 10 Contractor the tum of the lollowing: (1) ill expenses reasonably and necessarily incurred and to be incurred by Contractor by reason of the Contract and by reason of the premature lermination of the work. Including the expense of drilling or other crew members and supervision directly assigned lo the rig. (2) Ten percent (10\%) of the amount of auch reimbursable expenses; and (3) esum calculated at the itandby rate for ell time from the date upon which Contractor commences any operations hereunder down to such date ubsequent to the date of lermination as will afford Contractor reasonable time to dismantie his rig and equipment provided however. If this Contrect is tor a term of more than one weft or for a period of time. Operator shall pay Contractor. In addition to the above. the force majeure rate less any unnecessary labor from that date subsequent to termination upon which Contractor

(b) If auch vermination occurs efter the epudding of the well. Operator shall psy Contractor (1) the amount lor all pplicable deywork rates and all other charges and reimbursements due to Contractor, but in no event ahali such sum, exclusive of reimburcements due, be less than would have been earned for all deys as the applicable day rate Without Drill Pipe" and the ectual amount due for drill pipe used in accordance with the above rates; or at the election of contractor and in liev of the foregoing. Operator ahall pay Contractor for all expenses reasonably and necessarily incurred end to be incurred by reason of this Contract and by reason of auch premature iermination plus e ump sum of 8 . NA the ebove, the force majeure rate less any unnecessary lubor from the date of iermination until the end of the term or -

\section{CasmG PROGRAM:}

Contractor chall drill a well aufficient in tize to set, at the approximate depths indicated, the alze cesing specified in the casing program provisions of Exhbit "A. Operator shafi have the noht to designate the points at which casing will be set and the manner of setting. cernenting and lesting. Operator may modify the casing program, however, any such moditication which materially increases Contractor's hazards or costs can only be made by mutual consent of Operator and contractor end upon agreement as to the additional compensation to be pad Contractor is a resutt thereof.

4. DRLLNO METHODS AND PRACTICES:

2.1 Conirector stall maintain well control oquipment in good condition at all times and thall use all reasonable means to control and prevent fires and blow-outs and to protect the hole.

I.2 Subject to the terms hereot, and at Operator's cost, at all times during the drilling of the well. Operator shall have the right to control the mud program, and the drilling fluid must be of e bye and have characteristics and be maintained by

2.3 Contractor will conduct operations to comply with all lews, nules, orders, and regulations, Federal, State, and Loces which are applicsble to Contractor, Contractor's business, equipment, and personnel engaged in operations covered by this Contract, including but not limited to those eet forth in Exhiblt " $\mathrm{B}$ ".

0.4 Contractor shall keep and furniah to Operator an accurate record of the work performed and formations drilled on the ADC-API Daily Driling Report Form or other torm acceptable to Operator. A legible copy of eald form signed by Contrector's representative ahall be furnished by Contractor to Operator.

4.5 If requested by Operator. Contractor chall furnish Operator with copy of delivery tickets covering any muterial or atppties provided by Operator and recaived by Contractor.

2. WGRESS, EGRESS, AND LOCATHON

Operator hereby assigns to Contractor all necessary rights of ingress and egress with respect to the tract on which the well is to be located for the performance by Contractor of all work contemplated by this Contract. Should Contractor be denied free access to the location for any reason not reasonably within Contractor's control, any time lost by Contractor as a result of such denial ehall be paid for at the applicable rate.

10. SOUND LOCATION:

Operator chall prepare a sound location adequate in size and capable of property supporting the dritling rig. and shall be responaible for a conductor pipe program edequate to prevent toll and aub-soll wash out. it is recognized that Operator has resporior or obstructions de or bbstuctions propurtyce cond the caubin creation properly support the rig during marine operations hereunder, and loss or damage to the rig. Hs associated equipment of personnel results therefrom, Operator shall, without regard to other provisions of this Contract. including Paragraph 14.1 payment of force majeure rate during repair and/or demobilization $M$ applicable.

11. EOUIPUENT CAPACITY:

If applicable hereunder, operations chati not be attempted where eanal or water depths are in excess of NA

pereunder. Contrector feet, of under any oiner conditions which exceed the capactly of the equipment apecified to be used epecified equipment.

12. TEAMINATION OF LOCATION LABILT:

When Contractor has complied with all obligations of the Contract regarding restoration of Operator s location, Operator chall thereatter be liable for damage lo property, personal injury or death of any person which occurs as result of condition of the iocation und Contractor shall be relieved of such Hability; provided, however. in Contractor shall eubsequently reenter upon the location for any reason, including removal of the ils. eny lerm of the Contract relating to such reentry activity ehall become toplicable during such period.

13. insuRANCE:

During the Hise of this Contract, Contractor thall at Contractore expense maintain, with an insurance company or companies authorized to do business in the state where the work is to be performed or through a celf-insurance propram, insurance coverages of the kind and in the amounts set forth in Exhibh " $A$ ". Contractor enall. Mrequasted to do so by Operator. procure from the company or companies writing said insurance a certificate or certificates that eatd insurance is in full force and effect and that the came shaft not be cancelled or materially changed without ten (10) days prior written notice to Operator. 14. RESPONSIBILITY FOA LOSS OA OAMAOE:

14.1 Contractors Eurface Equlpment Contractor thafl assuma llablity at all Umes, lor damage to or destruction of Contractor's surface equipment, including but not limited to all driling tools, machinery, and appliances for use above the contrace, regardless of when or how such damage of destruction occurs, and Operator thall be under no liability to reimburse

142 Contrector's In+Hote Equipment: Operator ahall assume liabiliny at at times for damage to or destruction of

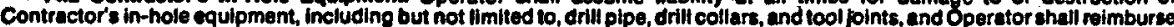
Contractor for the value of any uch loss or damage; the value to be determined by egreement between Contractor and Operator es current repair cost or 85 . percent of current new replacement cost of wuch equipment delivered to the well eite.

14.3 Coniractor's Equipment - Environmentel Lose or Damage: Notwithatanding the provisions of Paragraph 14.1 above. Operator hall assume liability at all times for damage to or destruction of Contractor sequipment cauted by exposure to highly corrosive or otherwise destructive elements, including those introduced into the drilling fluid. NTE $\$ 20,000,000.00$

14.4 Operator' Equipment: Operator shall essume liabitity at all times tor damage to or destruction of dperator's equipment, including but not Hmited to casing, lubing, well head equipment, and platform if applicable, end Contractor shall be under no liability to relmburse Operator for any such loss or damage.

145 Tha Hole: in the event the hole should be lost or damaged. Operator thall be solely responsibje for such damage or loss to the hole. including the casing therein.

14.6 Undorground Damage: Operator agrees to defend and indemnify Contractor for any and all claims against Contractor resulting trom operations under this Contract on account of injury to, destruction of, or loss or impairment of any property right in or to oil, gas, or other mineral substance or water, Hat the time of the sct or omission causing such injury, destruction, loss, or impairment, eaid substance had not been reduced lo physicsl possession ebove the surince of the earth sng for eny loss or damage to any formation, strata, or reservoir beneath the eurface of the earth. NTE $\$ 20,000,000,00$

(Deyworh Contrect - Pege 3) 
Revised Dec. 1975

14.7 Inspection of Materiats Furnithed by Operator. Contractor agrees to visually inspect alt materiais furnished by Operator befor using same and to notity Operator of any apparent defocts therein. Contractor shall not be liable lor any loss or Operator belore using same and to notify Operator of any apparent

14.8 Conirector's Indemnificetion of Operalor: Subject to the provisions of Article 12 hereof, Contractor agrees to prolect. defend, indemnify and save Operator and its joint owners harmless from and against all claims, demands, and causes of action of every kind and character, without limit and without regard to the cause or csuses thereof or the negligence of any party. arising in connection herewith in tavor of Contractor's employees. Contractor's subcontractors or their employees, on account of bodity injury, death or damage to property.

14.9 Operator's Indemnilication of Contractor Operator agrees to protect, defend, indemnify and asve Contractor harmless from and against all claims. demands and causes of setion of every kind and character, whout limit and without regard to the cause or causes thareof or the neglioence of eny panty, arising in connection herewith in favor of Operator's employees, Operator's contractors or their employees, other than those identified in 14.8 above, on account of bodily injury. death or damage to property. NTE $\$ 20,000,000.00$

14.10 Llabillity for WIId Well: Operator shall be llable for the cost of regaining control of any wild well, as well as for cost of removal of any debris, and shall indemnify Contractor in this regard. NTE $\$ 50,000,000.00$.

14.11 Pollution and Conlamination: Notwithstanding anything to the contrary contained herein, except the provisions of Paragraphs 10 and 12, it is understood and agreed by and between Contractor and Operator that the responsibility for pollution and contamination shall be es follow:

(a) Unless otherwise provided herein. Contractor shall assume all responsibility for. including control and removal of and protect, delend and save harmless Operator from and against alt claims, demands and causes of action of every kind and character arising from pollution or contamination, which originates above the surface of the land or water from spilis of fuels. Iubricents, motor oils, normal water bese drilling fluid, pipe dope, paints, solvents, ballast, bilge and garbage. excep unavoidable pollution fom reserve pits, wholly in Contractor's possession and control and directly associated with Contractor's cquipment and facilities.

(b) Operator sha!l assume all responsibility for, including control and removal of, protect, defend and save Contractor harmless from and against all claims, demands, and causes of action of every kind and character arising from all other pollution or contamination which may occur during the conduct of operations hereunder, Including but not limited to, that which may result from fire, blowout, cratering, seepage or any other uncontrolled flow of oil, gas, water or other substance, is well as, the use or disposition of oil emulsion, oil bese or chemically treated drilling fluids, contaminated cuttings or cavings, lost circulation and fish recovery materials and fluids. NTE $\$ 20,000,000.00$.

(c) In the event a third party commits an act or omission which results in pollution or contamination for which oither Contractor or Operator, for whom such party is performing work, is held to be legally liable, the responsibility therafor shall be considered, as between Contractor and Operator, to be the same as if the party for whom the work was pertormed had pertormed the same and all of the obligations respecting defense. indemnity. holding harmless and limitation of responsibility and liability, as set forth in (a) and (b) above, shall be specifically applied.

14.12 Consequential Damuges: Neither party shall be liable to the other for special, indirect or consequential damages resulting from or arising out of this Contract, including, without limitation, loss of profit or business interruptions, however same may be caused.

15. NO WAIVER EXCEPT IN WRITING:

It is fully understood and agreed that none of the requirements of this Contract shall be considered as waived by either party unless the same is done in writing. and then only by the persons executing this Contract. or other duly authorized igent or representative of the party.

16. FORCE MAJEURE.

Neither Operator nor Contractor shall be liable to the other for any delays or damage or any failure to act due, occasioned or caused by reason of any laws, rules, regulations or orders promuloated by any Federal, State or Local governmental body of the rules, regulations, or orders of any public body or official purporting to exercise authority or control respecting the operations covered hereby, including the procurance or use of fools and equipment, or due, occasioned or caused by strikes, action of the elements, water conditions, inability to obtain fuel or other critical materials, or other causes beyond the control of the party affected thereby. In the eivent that either party hereto is rendered unable, wholly or in part, by any of these causes to carry out its obligation under this Contract, it is agreed that such party shall give notice and details of Force Majeure in writing to the other party as promptly as possible after its occurrence. In such cases, the obligations of the party giving the notice shall be suspended during the continuance of any inability so caused except that Operator shall be obligated to pay to Contractor the Force Majeure Rate provided lor in Paregreph 4.7 above.

17. INFORMATION CONFIDENTIAL:

Upon written request by Operator, Information obtained by Contractor in the conduct of drilling operations on this well including. but not limited to, depth, formations penetrated, the results of coring, testing, and surveying, shall be considered confidential and shall not be divulged by Contractor or his employees, to any person, firm, or corporation other than Operator' designated representatives.

18. SUBCONTRACTS EY OPERATOR:

Operator may employ other contractors to perform any of the operations or services to be provided or performed by $n$ ccording to Exhibit "A".

19. ASSIGNMENT:

Nelther party may assign this Contract without the prior written consent of the other, and prompt notice of any such intent to assign shall be given to the other party. In the event of such assignment, the assigning party shall remain liable to the other party as a guarantor of the performance by the assignee of the terms of this Contrect. If any assignment is made that materially alters Contractor's financial burden. Contractor's compensation shall be adjusted to give effect to any increase or decrease in Contractor's operating costs.

20. NOTICES AND PLACE OF PAYMENT:

All notices to be given with respect to this Contract unless othenwise provided lor shall be given to the Contractor and to the Operator respectivaly at the addresses hereinebove shown. Alt sums payable hereunder to Contractor shall be payable at his address hereinabove shown unless otherwise specilied herein.

21. SPECIAL PROVISIONS:

21.1 Gruy Federal, Inc., General Provisions, with the execption of No. 17 "Key Personnel", are attached hereto and by thls reference made a part hereof. 21.2 Additional Provisions SP Safety Policy, IP Intellectural Property, SCA Service Contract Act, LMS Labor Surplus Area, Minority Business and Small Business Subcontracting Programs are attached hereto and by this reference made a part hereof.

22. ACCEPTANCE OF CONTRACT:

The foregoing Contract is agreed to and accepied by Operator this 9 th day of __ March $.19+79$

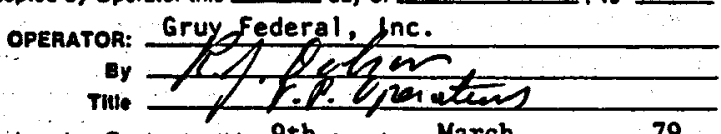

The foregoing Contract is accepted by the undersigned es Contractor this 9 th day of $\frac{\text { March }}{18} \quad 79$ which is effective date of this epreement. subject to rig availability. and subject 10 all of its terms and provisions, with the understanding that uniess eaid Contrect is thus executed by Operator within days of the above date.

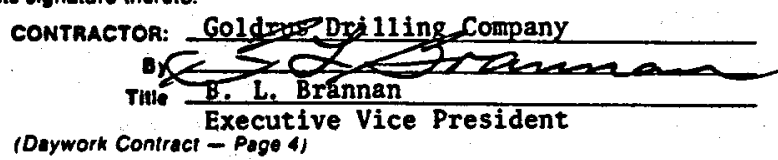


EXHiBIT "A"

Revised Dec. 1975

March 9.

$19 \div 79$

To Daywork Contract datod

Contractor

GOLDRUS DR ULTWG COMPANY

Operator GRUX FEDERAL, INC.

Fal fax Foster Sutter No. 2

Well Name and Number

SPECIFICATIONS AND SPECIAL PAOVISIONS

1. Casing phograu (see Par. $n$

slze

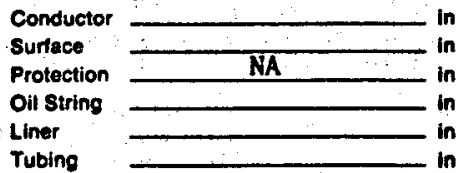

- Mu control PROCRAN (s. Par (a)

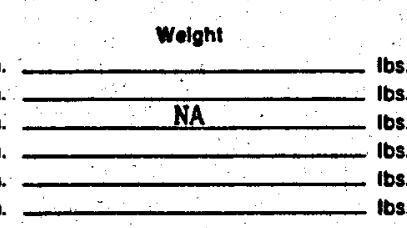

Approxinate seitung Depth Ibs./th.

Ibs./th.

10s./n.

Ibs./ft

tos $/ t$

Dopth Interval

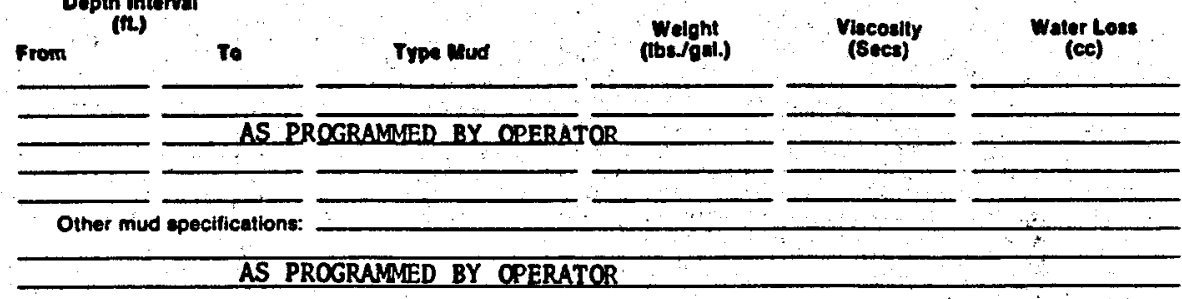

2 INSUAANCE (see Par. 13)

2.1 Adequate Workmen's Compensation Insurance complying with State Lews applicable or Employers' Liability Insurence with limits of $\$$ ___ covering all of Contractor's employees working under this agreement.

22 Comprehensive Public Llability Insurance or Public Liability Insurance with limits of $\$$ death or injury of any one person and \$__ for each accident.

23 Comprehensivo Public Liability Property Damage Insurance or Public Luability Property Damage Insurance with limits

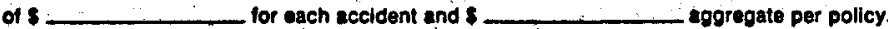

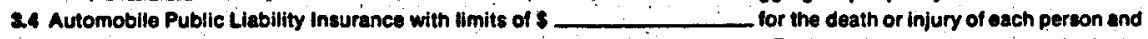
f for each accident; and Automobile Public Liablity Property Damege Insurance with limits of 5 for ach accident.

2.5 in the ovent operations are over water, Contractor shall carry in eddition to the Statutory Workmen's Compensation Insurance, endoreements covering lability under the Longshoremen's \& Marbor Workers' Compensation Act and Maritime liability including maintenance and cure with limits of $\$$ peraon and 8

26 Other Insurance:

Per certificates of insurance furntshed by our agent upon request

4. EOUIPUENT, MATERIALS AND EEAVICES TO BE FUANISHED BY CONTAACTOR:

The machinery, equipment, tools, meterials, supplies, Instruments, eervices and tabor hereinafter liated, including any transportation required for such items, thall be provided the location at the expense of Contractor unless otherwise noted hereon.

4.1 Orliting Alo:

Complete drilling rig designated by Contractor as his Fig No. 15

Drawworks: Per attached inventory

Engines: Make, Model, and H.P.

No. on Rig

Pumps: No. 1 Make, Size, and Power

No. 2 Make, Size, and Power

Mud Mixing Pump: Make, Size, and Power

Bollers: Number, Make, M.P. and W.P.

Derrick or Mast: Make, Size, and Capacity

Substructure: Size and Capacity

Rotary Drive: Type

Drill Pipe: Size

Drill Collars: Number and Size

Blowout Preventers:

sl2e

(Make and Model)

the major ltems of equipment being

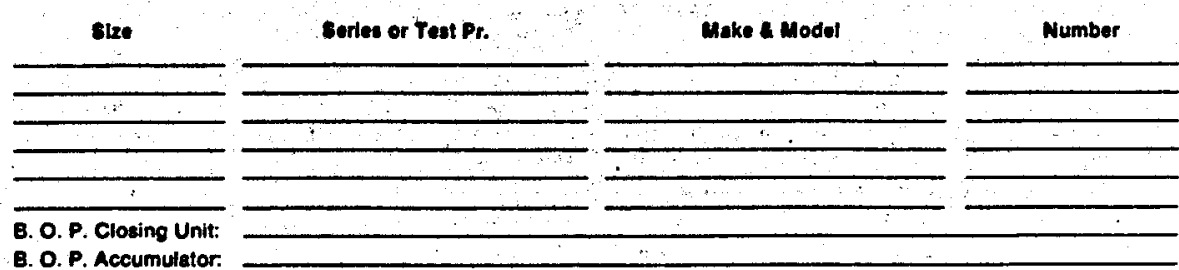

(Daywork Contract - Exhibit "A" - Page 1) 
4.9

4.12

4.13

4.14

4.15

416

417

2. EOUIPUENT, MATERIALS AND SEAVICES TO BE FUANISHED BY OPERATOR:

The machinery, equipment, tools, materials, eupplies, Instruments, services and lebor hereinafter listed. including any transpontation required for wuch hems, shall be provided it the location at the expense of Operator unless otherwise noled hereon.

81 Furnish and maintain adequate roadway and/or canal to location, right-of-way, including inghts-of-way for fuel and water lines, river crossings, highway crossings, gates and cattie guards.

12 Stake Iocation, ctear and gade locetion, and provide tumatound including surfacing when necessary.

8.3 Test tenks with pipe and ittings.

8. Mud storage tanks with pipe and fittings.

8.5 Separator with pipe and tittings.

Le Labor to connect and disconnect mud tank, test tank, and soparator.

8.7. Labor to disconnect and clean test tanks and separator.

is Drilling mud, chemicals, lost circulation materials and other additives.

6. Pipe and connections for oil circulating lines.

a 10 Lebor to tay, bury and recover oil circulating lines.

S.11 Drilling bits, reamers, reamer cutters, stabilizers and special tools.

S.12 Contract fishing tool services and tool rental.

C13 Wire line core bits or heads and wire line core catchers if required.

s.14 Conventional core bits and core catchers.

S.15 Diamond core barrel with head.

Q16 Cement and cementing service.

5.17 Electrical and Gamma-Neutron and Micro logging services.

Q18 Directional, caliper. or other upecial services.

8.19 Gun or jet perforating services.

820 Explosives and shooting devices.

S21 formation testing. hydraulic fracturing, acidizing and other relatod services.

Q22 Equipment for drifl stem tosting.

273 Mud logging services.

L24 Sidewall coring tervice. talling of well head equipment if required.

5a Cesing tubing thes, ecreen, lloat collars. guide and float shoes and associated couipment.

27 Casing scratchers and centralizers.

0.38 Well mead connections end ell equipment to be installed in or on well or on the premises for wes in connection with testing. completion ind operation of welt.

99 Special or edded storege for mud and chemicals.

Ton Casinghead, API series, 10 conform to that shown for the blowout preventers epecified in Paragraph 4.1 above.

6.31 Casinghead, APl series, 10 coniort

c.32 Casing Thread Protectors and Casing Lubricants.

$\mathbf{5 3 3}$

5

5.35

5.36

5.37

5.39

$\mathbf{5 . 3 9}$

8.41

C. EQUIPMENT, MATERIALS AND SEAVICES TO DE FURNISHED EY DESICNATED PARTY:

The machinery, equipment, tools, materials, cupplies, Instruments, eervices, and labor liteted as the following numberad thems including any transportation required for such hems untess otherwise specified. shall be provided at the location and at the expense of the party hereto as designated by an $X$ mark in the appropriate column.

tem

C.1 Cellar and runways

C.2 Fuel llocated at

6.3 Fuel Lines (length

6. Water at source, including required permite

6.5 Water well, including required permits

6.8 Water lines, including required permits

6. Water storage lanks

c. Labor to operate water well or water pump

c.8 Maintenance of water well, it required

c10 Mats lor engines and bollers or motors and mud pumps

C.11 Transportation of Contrector's property:

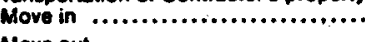

Move out ..............................

C.12 Materials for "boxing in" fig and derrick

C.13 Speciat atrings of drill pipe and drill collars os foilows:

Dril pipe smaller than 4-1/2": 0.D Drill collers smaller than $6-3 / 4 "$ on
To Be Proplded By and

Opergtor Contractor

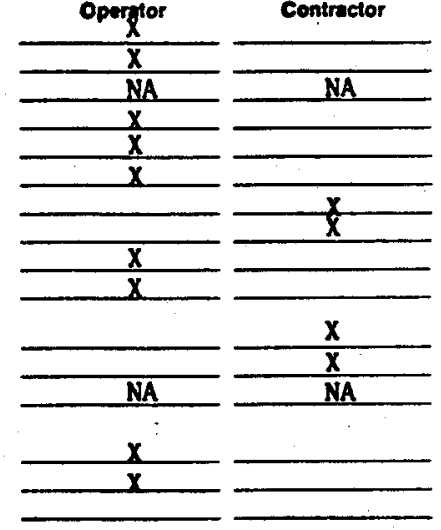

(Daywork Contrect - Exhion " $A "$ - Page 2) 
Revised Dec. 1975

To Be Prowided Qy ind
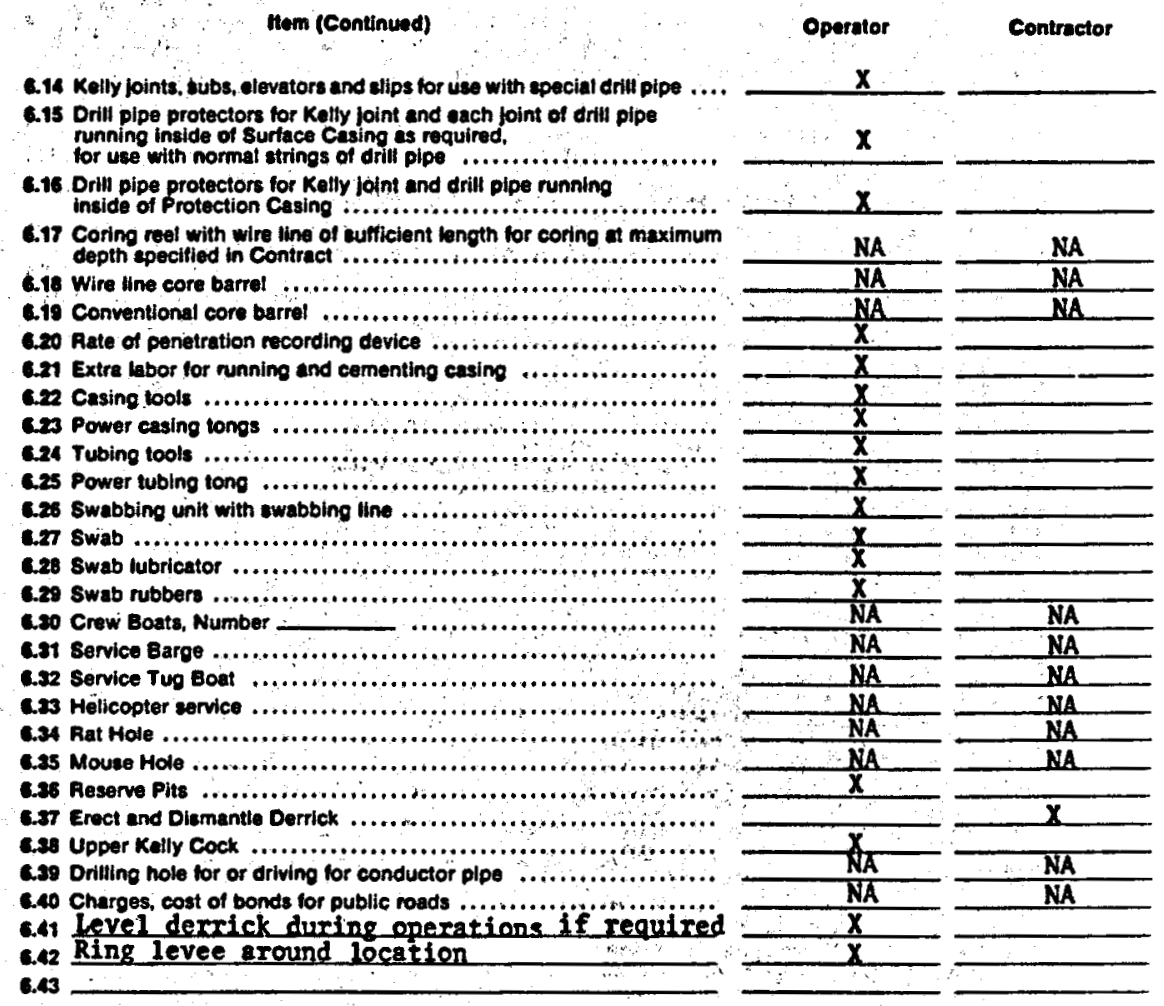

7. OTHER PROVISIONS:

7.1 Day rates will commence at 7:00 a.m. on March 8, 1979.

7.2 Commitments against contract shall not exceed $\$ 39,000.00$ without prior approval of operator.

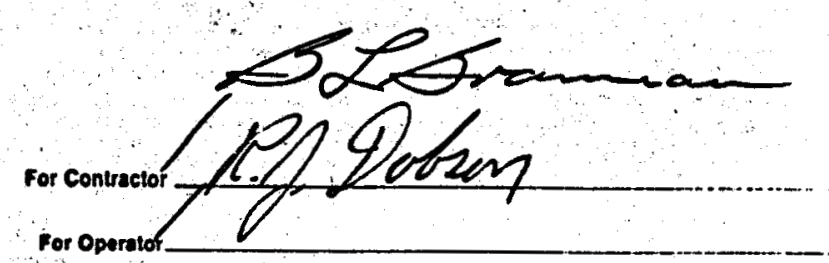

10oywork Contract - Exhibit "A" - Page 3) 


\section{EQUAL EMPLOYMENT OPPORTUNITY}

A. Operator is an Equal Opportunity Employer. It is agreed as a condition of this Contract that unless any or all work performed hereunder is exempt under Executive Orde 11246 (30 Fed Pen 12319) regulations issued thereunder, during the pertormance of this Contract, the Contractor agrees as follows:

1. The Contractor will not discriminate against any employee or applicant for employment because of race, retigion, color, ex or national origin. The Contractor will take affirmative action to ensure that applicents are employed, and that employees are treated during employment, without regard to their race, religion, color, sex or national origin. Such action shall include, but not be limited to the following: Employment, upgrading. demotion, or transfer; recruitment or recruitment advertiaing: layoff of termination; rates of pay or other forms of compensation; and selection for training, including apprenticeship. The Contractor agrees to post in conspicuous places, evaliable to employees and applicants for employment, notices to be provided by the contracting officer setting forth the provisions of this nondiscrimination clause. 2 The Contractor will, in all solicitations or advertieements for employees placed by or on benalf of the Contractor, state
that all qualified applicants will receive consideration for employment without regard to race, religion, color, sex or national origin.

3. The Contractor will send to each labor union or representative of workers with which he has a collective bargaining greement or other contract or understanding. notice to be provided by the egency contractine officer. advising the labor 1965, and shatl post coples of the notice in conspicuous places avaitable to employees and applicants for employment.

4. The Contractor will comply with all provisions of Executive Order 11246 of September 24, 1965, and of the rules, regulations, and relevant orders of the Secretery of Labor.

5. The Contractor will furnish all information and reports required by Executive Order 11246 of September 24, 1965, and by the rules, regulations, and orders of the Secretary of Labor, or pursuant thereto, and will permit access to his books, records, and eccounts by the contracting egency and the Secretary of Labor for purposes of investigation to ascertain compliance with such rules, regulations, and orders.

6. In the event of the Contractor's noncompliance with the nondiscrimination clauses of this Contract or with any of such rules, regulations, or orders, this Contract may be cancelled, terminated. or suspended in whole or in part and the Contractor may be deciared ineligible for further Government contracts in accordance with procedures authorized in Executive Order 11246 of soptem

7. The Contractor will include the provisions of Paragraphs 1 through 7 in every aubcontract or purchase order uniess axempled by nules, regulations, or orders of Secretary of Labor issued pursuant to Section 204 of Executive Order 11246 of September 24, 1065, so that such provisions will be binding upon each subconiractor or vendor. The Contractor will take such sction with respect to any subcontract or purchase order as the contrecting eoency mey direct es a meana of enforcing such provisions including sanctions for noncompliance: Provided. however, that in the event the Contractor becomes imolved in, or is threatened with litigation with a subcontractor or vendor as a result of such direction by the contracting agency, the Contractor may request the United States to enter into euch litigation to protect the interests of the United States.

B. Fithe standard Form 100 (EEO-t) and Development of Aftimative Action Program.

1. Contractor acknowledges that he may be required to file Standard Form 100 (EEO-1) promulgated jolntly by the Ofice of Federal Contract Compliance, the Equal Employment Opportunity Commission and Plons for Progress within thint (30) days of reports es may be required under Executive Order 11246, is amended and Rules and Regulations adopted thereunder.

2 Contractor further acknowledges that he may be required to develop a written attirmative action compliance program as required by the Rules and Regulations approved by the Secretary of Lebor under authority of Executive Order 11246 and eupply

\section{Honsegregated Factitien.}

Contractor certifies that he does not maintain or provide for his employees any segregated facllities at any of his establishments, and that he does not permit his emplovees to pertorm their services at any location, under his control, where egregated facilities are maintained. He cortifies further that he will not maintain or provide for his employees any segregated facilities at any of his establishments, and that he will not permit his emplovees to pertorm their sentices at any location, under his control, where segregated tacilities are manisined. Contractor agrees that a breach of his certification is a violation of the Equal Opportunify Clause in this Contract. As used in this certification, the term - vegregated faclities" means any watting rooms, work areas, resf rooms and wesh rooms, restaurants and other eating areas, time clocks, locker rooms and other morese or dressing areas, parking lots, drinking fountains, recreation or entertainment areas, iransportation and housing fecllities provided for empioyees which are segregated by explicit directive or are in fact eegregated on the basis of race, color, religion. sex, age or national orioin, because of nabit. local custom or otherwise; Contractor's policies and practices must assure appropriate physical facilities to both eexes. He further acrees that (except where he has obtained identical certifications from proposed subcontractors for epecific time periods) he wil obtain identicel certitications from proposed subcontractors prior to

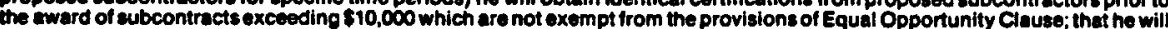
retain such certifications in his files; and that he will forward the following notice to such proposed eubcontrectors (exceot where the proposed subcontractors have submitted identical certifications for specific time periods): NOTICE TO PROSPECTIVE SUBCONTRACTOAS OF REOUIREMENT FOR CERTIFICATIONS OF NONSEGREGATED FACILITIES. A Certification of Nonsegregated Facilities as requined by the May 21, 1968 , order on Elimination of Segregated facillties by the Secretary of Labor (33 Fed. Reg. 7804, May 28, 1068), must be submitted prior to the award of a subcontract exceeding $\$ 10,000$ whlch is not exempt from the provisions of the Equal Opportunity Clause. The certification may be submitted either for each subcontract or for all subcontracts during e period (i.e., quarterly, eemiannually, or annually)."

\section{Penaltles}

Contractor further understands and agrees that a breach of the assurance contained in Paragraphs A through $\mathbf{C}$ above uubjects it to the provisions of the Order 41 CFR Chapter 69 of the Secretery of $L$ bor dated May 21,1958 in the ovent of Contractor's noncompliance with the nondiscrimination clauses of this Contract or with any of such rules, regulations, of orders Contract on the basis of such noncompliance with no further obliogtion whatsoever on the part of the Operator.

\section{LISTING OF EMPLOYMENT OPENINCS}

The underaigned Contractor further agrees, If the value of any contract or purchase order is $\$ 2,500$ or more. that it will be bound by the following provisions contained in 41 CFR 50-250 promulgated pursuant to Executive Order No. 11701:

A. The Contractor, to provide special emphesis to the employment of qualified disabled veterans and veterans of the Vietnam era, egrees that all suitable employment openings of the Contractor which exist at the time of the execution of this Contract and those which occur during the performence of this Contract, including those not oenerated by this Contract and including those occurring at an eats blishment of the Contrector other then the one wherein the Contract is being performed but excluding those of independently operated corporate ffiltates hall be oftered for tisting at an contractis beling porformed but oxcluding those ervice system wherein the opening occurs es hires as may be required; Provided. That this provision shall not epply to openings which the Contractor fills from within the Contractor's organization or are filled pursuant to a customary and traditional employer-union hiring arrangement.

B. Liating of employment openings with the employment service system pursuant to this clause shall be made at least concurrentiy with the use of any other recrultment service or offort and ahall involve the normal obligations which attach to the placing of a bonafide job order, including the scceptance of referrals of veterans and nonveterans. The listing of employment openings does not require the hiring of any particular job applicant or from any particular group of job applicants, and nothing herein is intended to relieve the Contractor from any requirements in any Executive Orders or regulations regarding 
International Association of Drilling Contractors DRILLHE BID PROPOSAL

Howard's Well Service

\begin{tabular}{l} 
P. O. Box 985 \\
\hline Jennings. $1 \mathrm{~A} 20546$ \\
\hline
\end{tabular}

Please submit bld on this drilling contract form for pertorming the work outlined below, upon the terms and for the consider ation set lorth, with the understanding that it the bid is accepted by Gruy Federal, Inc.

this instrument will constitute e contract between us. Your bid should be mailed or delivered not later than _:00_P.M. on April 17th 1979 . to the following address:

Gruy Federal. Inc, 2500 Tanolewlide. Sulte 150

Houston, Texas 27063

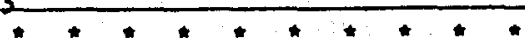

THIS AGREEMENT, made and entered into on the date hereinafter set forth by and between the parties herein designated as Operator" and "Coniractor".

OPERATOR: GruY Federal. Inc.

Addres: -2500 Tanglewilde, Sulte 150

Houston. Texas 77063

contractor: Howard's Well Service

addres: : P. 0. Box 985

Jennings. LA 70546

IN CONSIDERATION of the mutual promises, conditions and agreements herein contained and the specifications and specia provisjons set forth in Exhibit " $A$ " and Exhibli " $B$ " attached hereto and mede a part hereof, Operator enoages Contractor us an independent Contractor to furnish the equipment and labor to drill the hereinafter designated well or welis in search of oil or gas on a darwork basis.

Contractor agrees to lurnish equipment meeting the specilications designates herein, and capable of drilling fo the depth indicated herein, including equipment capable of drilling in the whtor depths herein indicated th this Contract involvas a marine operation. Contractor further agroes, subject to all other applicable cleuses of this Contract. to provide any and all services required eccording 10 the specilications stated herein. Ih is expressly understood and agreed ro by Operator and contractor that auch services ers performed of ine approphiete daywork rote, and the pertormance of such services by Contrector in no way subjects him to lability for any risk nor disewhere assumed oy him under the terms of this Contract. Contractor agrees to Doriorm all work ro be conduelod by him under tho lerme of his coniraci in accordance with the orders and directions of Operafor, with due diligence and care and in e good and workmanlike manner, and agrees to provide competent supervision of
the work performed hereunder.

1. LOCATION OF WELL:

Well Name As Dl rected by Operator
and Number. As

Parish St. Mary state LA

Well bosantion and

State: LA

Fiela Name: N/A

Well location and As Di rected by Operator
land description:

1.1 Additional Well Locatlons or Arens: $N / A$

Locations described above are for well and contract identfication only and Contractor assumes no liability whatsoever for a proper survey or location stake on Operator's lease.

2. COMMENCEMENT DATE:

Contractor sgrees to use best efforts to commence operations for the drilling of well by the $\frac{18 \mathrm{th}}{\text { day of }}$ April 1979 or Location is now ready. Not if ication has been Given to contractor

8. DEPTM:

3.1 Well Depth: The well (s) chall be drilled to depth of approximately 4,000 feet, of to the Injection Sand_formation, whichever is deeper, but Contractor shall not be required hereunder to drill eaid well (s) betiow a maximum depth of 4,000 feet, uniess Contractor and Operator mutually agree to drill to a greater depth.

\section{DAYWORK RATES:}

Contractor athall be paid at the following rates for the work performed hereunder.

4.1 Mobllization: Operator ahall pay Contractor a mobilization lee of $\$$ - N/A - N/A per 24 hour day. This sum shall be due and payable in tull at the time the rig is rigoed up or positioned a the well site ready to spud. Mobilization shall inctude: "Be included in "ITurn-Key" price to 4,000 foot depth

4.2 Demobllization: Operator shall pay Contractor a demobilization lee ol \$ N/A rate during lear down of \$_ N/A___ per 24 hour day. provided however that no demobilization foes shall be payable if the contract is terminated due to the lotal loss or destruction of the rig. Demobilization shall mefuce. be inc] uded In "ITrn-Key" prlee to h,000 foot depth

43 Mowing Rate: Duting the time the rig is in transh to or from drill slle, or between drill sites, commencing on N/A Operator shall pay Contractor s sum of $\$$ N/A per iwenty-four (24) hour day.

44 Operating pay Rate: For work performed per twenty-lour (24) hour day with 5 tandard man crew the operating day rate shall be:

Lepth Intervals


If under the ebove column "With Drll Pipe" no cay rates are speeified, the daywork rate pertwenty-lour hour day when drill pipe is in use shall be the applicable daywork rate apecified in the column "Without Drill Pipe" plus compensation for eny drill pipe setually used at the rates specified below, computed on the basis of the maximum drill pipe in use at any time during each iwenty-four hour day.

DRILL PIPE RATES PER 24-HOUR OAY

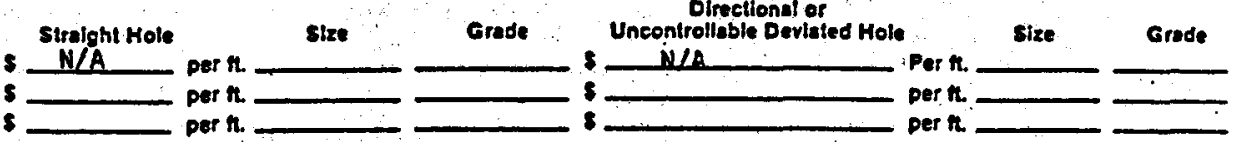

Drill pipe shall be considered in use not only when in actual use but also while it is being picked up of laid down. When drill pipe is stending in the derrick, th shatl not be considered in use. provided, however, that it Contruetor lurnishes special strings of drill pipe. drill collar, and handling tools as provided for in Exhibit " $A^{\prime \prime}$, the same shall be considered in use at all times when on dofll pipe. drill collar, and handling tools as provided for in Exhibit 'A the same shali be considered in use an all times when on location or until released by Operator. In no event shall tractions of anhour be coneidered in compuling the amount of time drill less than thirty minutes not to be counted.

Operating rate will begin when the driling unit is rigged up at the drilling location. or positioned over the location during marine work, and ready to commence operations; and will case when the rig ls ready to be moved off the location.

4.5 Repoir Rote: in the event his necessary to shut down Contractor's rig for repeirs, exeluding routine rig servicing, while Contractor is pertorming daywork hereunder. Contractor shall be ellowed compansation at the applicable da wwork rate for each

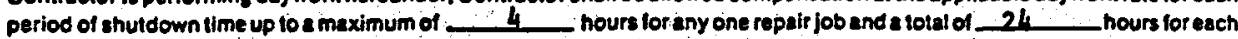
thiny (30) day period. Thiereatter, Contractor shall be compensated at a rate of $\$-0=\ldots$ per twenty-iour (24) hour day Repair rate to apoly only on day rate bas ls

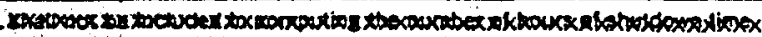

4.6 siandby Time Rate with Crewe \$2,1,00 on : per'lwenty-four (24) hour day. Standby time shall be defined to include time when the rig is thut down atthough in readiness to begin or resume operations but Contractor is waiting on orders of Operator or on materials, services or other htems to be lurnished by Operator.

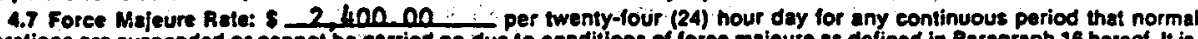
operations are suspendad or cannot be cerried on due to conditions of lorce majeure as defined in Paragraph 16 hereof. It is. however, understood that Operiator can release the rig in aceordance with Operator's right to direct stoppage of the work. effective when conditions will permit the rig to be moved from the locstion.

4.8 Relmbureable Costs: Operator shall reimburse Contractor for the costs of material, equipment, work or services which sre to be furnished by Operator as provided for herein but which for convenience are actually furnished by Contractor at Operator's request, plus N/A percent tor such cost of handing.

4.8 Revision in. Rales: The rates end/or peyments herein set forth due to Coniractor from Operator shall be revised to reflect the change in cosis if the costs of any of the llems hereinafter listed shall vary by more than N/A percent from the cocts thereol on the date of this Contract or by the same percent after the date of any revision pursuant to this paragraph:

(a) Labor costs, Including all benofits, of Contractor's personnel,

b) Contractoris cost of insurance pramiums:

c) Contretor's cost of fuel, the cost per osilon/Mef being \$ $\mathrm{N} / \mathrm{A}$

(d) Contractor's eost of catering, when applicable;

6) 11 Operator requires Contractor to Increase or decrease the number of Contractoris personnel:

(1) Contractor's cost of epare parts and bupplies with the understanding that such spare pans and supplies constitute $\mathrm{MLA}$ percent of the Operating Rate and that the parties shall use the U. S. Bureau of Lebor Statistics Oilfield Drilling Mechinery and Equipment Wholesale Price Index (Code No. 1181-02) to.determine to what extent a price varlance has occurred in aajd spare parts and supplies.

(o) If there is any change in legislation or regulations in the area in which Contrector ts working or other unforeseen, un. usual event that allits Contractor's finanelal burden.

8. TIME OF PAYMENT:

Subject to Operators right to require that Contrector furnish him with satistactory evidence that Contractor has paid all labor and material claims chargeable to Contractor, payment becomes due by Operator to Contractor as follows:

S.1 Payment for mobilization, drilling and other work performed at epplicable day rates, and all other applicable charges shall be due upon acceptance by Operator of the work pertormed in accordance with this Contract, upon presentation of invoice theretor upon completion of moblization, completion of the well, or st the ond of the month in which such work was pertormed or other charges afo incurred, whichever shall tirst occur. All invoices may be mailed to Opo

unless Oparai or does hereby designate that buen invoices shati be mailed as follows:

s.2 Any sum or eums not pald within 30 . days after the date of invoice shall bear interest at the rate of $1-\frac{1}{1}$ percent per _ month . _ or the maximum legal rate. whichever is less, from such date unill paid.

S.3 Attorney's Fees: It this Contrect is placed in tho hands of an ettorney for collectlon of any sums due hereundet, or sult is brought on same, of sums due hereunder are collected through bankruptey or probate proceedings, then Operator agrees that there shall be added to the amount due reasonableattorney's fees and costs.

6. TEAM:

6.1 Durtion of Contract This Contract shall remain in full force and eftect until drilling operations are completed on the well or wells specilied in Paragreph 1 above, or for a term of $N / A$ Paragraph 2 above

6.2 Extenslon of Term: Operator may extend the term or this Contract for N/A well (s) or for a period of $\frac{\mathrm{N} / \mathrm{A}}{\mathrm{N} / \mathrm{A}}$ by olving nolice to Contrictor at least $\mathrm{N} / \mathrm{A}$ days prior to completion of the well then beingdrilled

6.3 Eerty Terminatlon:

(a) By Elther Party: Upon giving of written notice, efther party may terminate this Contract when conditions of lorce majeuin, ior.

(b) Ey Optrutor. Notwithstanding the provistions of Paragraph 3 with respect to the depth to be drilled. Operator shall have the right to direct the sloppage of the work to be periormed by. Contractor hereunder at any time prior to reaching the specified depth, and even though Contractor has made no deleutt hereunder. in such event Operator shall reimburse Contractor set forth in sub-paragraph 8.4 hereot.

(c) Ey Contraclor. Notwithstending the provision of Paragraph 3 with respect 10 the depth to be drilted, in the event Operator shall become insoivent, or be adjudicated a bankfupt, of fite, by way of petition or answer, a debtor's petition or other pleading seeking adjustment of Operator's debts, under any bankruptey or debtor's reliet laws now or hereatter prevailing. or if any such be filed against Operator, or in esse a receiver be appointed of Operator or Operator's property, or any pan thereof, or Oseraior's aftairs be placed in the hands of Creditor's Committes. Contrestor mey, st his oplion. elect to terminate funther perfotmance of any work uncer this Contrset and Contractor's right to compensation shall be as set forth in subparacrash 6.4 Re-eet In atdition 10 Coritrator is tight to terminate performance hereunder. Operstor hereby expressty sorees to protect.

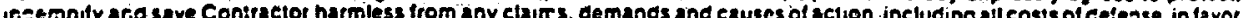

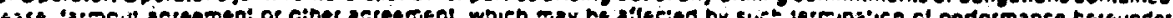

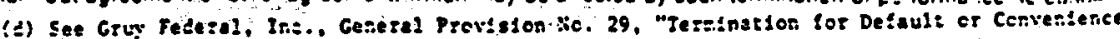
ef the Goveriven:". 
Revised Dec. 1975

6.4 (a) If such termination occurs prior to the spudding of the well. Operator shall pay to Contratior the sum of the following: (1) ell expenses reasonably and necessatily ineurres and to be inculred by Contractor by reason of the Coniract and by resson of the premature lermination of the work, including the expense of drilling or orher crew members and supervision directly assigned to the rig. (2) Ten percent (10\%) of the amount of sueh reimbursable expenses; and (3) a sum calculated at the standby rate for all time from the date upon which Contractor commences any operations harounder down to such cate cubsequent to the date of termination as will afford Coniractor reasonable lime to dismanile his rig and equipment provioted however, Hit this Contract is tor a completes dismantling his rip ind gquipment until the und of the term of See Exh ib it "Af 7.1

(b) If such termination occurs after the spudding of the well. Operator shafl pay Contractor (1) the amount for all epplicable daywork rates and all other charges and reimbursements due to Contractor; but in no event shall such sum, exclusive of reimbursements due, be less than would have been earned for See natedays at the applicable day rate Without Drill Pipe". and the setual smount dua for dritl plpe used in accordance with the above rates; or al the election of Contractor and in lieu of the forepoing. Operator shall pay Contraetor for all expenses reasonably and necessafily incurred and to be incurred by reason of this Contract and by reason of such premature termination plus s lump sum of $\$ \frac{-n-}{\text { - }}$. provided. however, it this Contract is for a term of more than one well or for a period of time. Operator shall pay Contractor, in addition to ine above, the lorce majeure rate less any unnecessary labor from the date of termination until the end of the term or see Exhlbit "A"I I

7. Casing paogram: All casing to be furnlshed by Operator

Contractor shall drill a well sufficient in size to set, at the approximale depthor indicified, the size cesing specified in the cesing program provisions of Exhiblt "A". Operator shall have the right to designate the points at which cassing will be set and the manner of setting, cementing and testing. Operator may modify the casing program, however, any such moditicalion which materially increases contracior's hazards or costs can only be made by mutual consent of Operator and contractor and upon apreement as to the edditional compensation to be paid Contractor as a result theroot.

- DRILLING METHODS AND PRACTICES:

E.1 Contraetor shall maintain well control equipment in good condition at all times and shall use all ressonable means 10 control and prevent fires and blow-outs and to protect the hole.

8.2 Subject to the terms hereof, and at Operator's cost, at all times during the drilling of the well, Operator shall have the right to control the mud program, and the drilling fluid must be of a type and have characteristics and be malntained by Contractor in eccordance with the specifications shown in Exhibit "A".

6.3 Contractor will conduct operations to comply with all laws, rules, orders, and regulations, Federsl, State, and Loca! which are applicable to Coniractor. Contractors business, cquipment,

8.4 Contractor shall keep and furnish to Operator an accurate record of the work performed and formetions drilled on the LADC-API Daily Drilling Repon Form or other form acceptable to Operatot. A legible copy of said form signed by Contractors representative shatl be fumished by Contractor to Operator.

1.5 if-requested-opereser- Contractor shall furnish Operator with copy of defivery lickets covering any materiel or supplies provided by Operator and received by Contractor.

Q. INGRESS, EGRESS, AND LOCATION:

Operator hereby assigns to Contractor all necessary rights of ingress and egress with respect to the traet on which tha well is to be loceled for the pefformance by Contractor of all work contemplated by this Contract. Should Contractor be denied iree access to the location lor any reason not reasonably whin Contractor's control, any time fost by Contractor as a result of such denisl shall be paid for at the applicable rate.

10. SOUND LOCATION:

Operator shill prepare a sound location adequate in tize and capable of properly eupporting the drilling rig, and shall be responsible for a conductor pipe program edequate to prevent soil and sub-eoil wash oul. 11 is recognized that Operator has superior knowledge of the location and access routes to the location, and must advise Contractor of any sub-surface conditions. superior knowledge of the locaton migh encounter while en route to the location or during operations hereunder. In the event sub-surtace conditions cause erstering or shifting of the location surface, or if seabed conditions prove unsatisfoctory to sub-suriace conditions cause 2 cratering or shiting ol the locstion suriace, or in seabed conditions prove unsatistactory to properly suppont the rig during marine operations hereunder. end loss or damege to the rig. hs associared equipment or personnel results therefrom, Operator shall, without regard to other provisions of this Contract, including Paragraph 14.1 hereof, reimburse Contractor to the extent not covered by Contractor insuran

payment of torce majeure rate

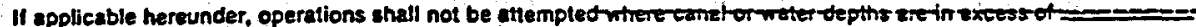
hereunder. Contrector ahalt make final decision as to when an operation or attempted operation would exceed the capacity of specified nquipment.

12. TERMINATION OF LOCATION LIABILTTY:

When Contractor has complied with all obllgations of the Coniract regarding restoration of Operator's location, Operator shall thereatter be liable for damage to property. personal injury or death of any person which occurs as result of condition of the location and Contrselor shall be relleved of such liabllity, provided, however, il Contractor shall subsequently reenter upon the location for any reason, including removal of the rig. sny leem of the Contract relating to such reentry activity shall become applicable during such period.

13.

During the lite of this Contrate At conteched, all at Contractor's expense maintain, with en insurance company or companies authorized to do business in the state where the work is to be periormed or through a seli-insurance program, insursnce coverages of the kind and in the amounts set forth in Exhibit "A". Contractor shall, it requested to do so by Operator. procure trom the company or companles writing said incurance a certificate or certificates that said insurance is in full force and effect and that the same shall not be cancelled or malerially changed without ten (10) days prior written notica to Operator. 14. RESPONSIBILTTY FOR LOSS OR DAMACE:

14.1 Contractor's surtace Equipment: Contractor shall assume liability at all times, for damege to of destruction of

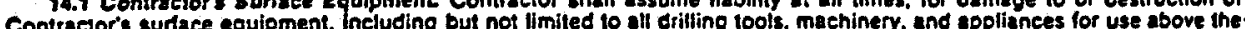
Contractor's surface equipment, Ineluding but not limiled to all drilling tools, machinery. and sppliances for use above the surface, regardless of when or how such damage or destruction occurs, end Operator shall be under
Contractor for any euch loss except loss or damage undet the provisions of Paragraphs 10 or 14.3.

14.2 Contractor's In-Hole Equipment Operator shall assume liability at all limes for damage to or destruction of Contractor's in-hole equipment, including but not limited to, drill pipe, drill collars, and tool joints, and operator shall reimburs: Contractor lor the value of any such loss or damage; the value to be determined by ugreement between Contractor and Operstor es cirrent repair cost or 100. _. percent of current new replecement cost of such equipment delivered to the well site.

14.3 Coniractor's Equipment - Environmental Loss or Damsge: Noiwithstending the provisions of Paragraph 14.1 above.

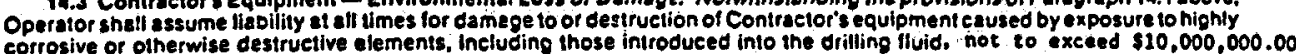

14,4 Operator's Equlpment: Operator shall essume lisbility al all times lor damage to or destruetion of Operator's equipment. including but not limited to cesing, fubing. Well head tquipment. end plattorm if applicable, and Contractor shall be uncer no liability to reimburse Operator for any sueh loss or damage.

14.5 the Hole: in the event the hole should be lost or dameged. Operator shall be solely responsible for such damage or loss to the hole. including the easing therein.

14.6 Underground Damage: Operator agrees to ceiend ane incemnify Con:racior for any anc all claims afainst Coniractor.

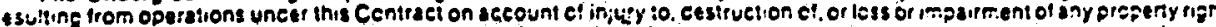

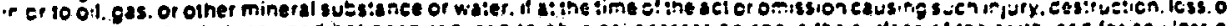

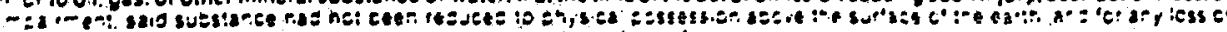

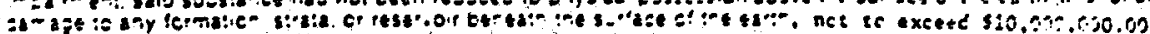

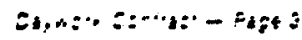


- 14.7 Inspection of Maleriale ished by Operator Contractot agrees to vis. - lly inspect all materials fornished by Operator before using same and to notily Operator of any apparent defects therein. Contractor shall not be liable lor any loss or camape resulting trom the use of materials lurnished by Operator.

14.8 Contractor's indemnificalion ol Operelor. Subject to the provisions of Anicle 12 hereof, Contractor agrees lo protect. defend, indemnify and save Operator and its joint owners harmless lrom and gainst all claims, Cemends, and causes of action of defend, indemnify and save Operal limit and without regard to the cause or causes thereol or the negligence of any farty, arising every kind and character, without limit and without regard to the cause or causes thereol or the negligence of any pany, arising in connection herewith in tavor of Contraclor

14.8 Operator's Indemnification of Contrator. Operator agrees 10 prolest, delend, indemnily and save Contractor harmless from and against all elaims, demands and causes of ettion of every kind and cheracter, withoortimit and without recard to the csuse or causes thereo! of the megligence of any pany, arising in connection herewith in favor of Operator's employees, Operator's contractors or their employees, Olher than those identilied in 14.8 above. on sccount of bocily injury. death of damage to property. not to exeeed $\$ 10,000.0 \mathrm{~m} \mathrm{~m}$

14.10 Wabilty for Wild Well: Operotor shall be liable tor the cost of regainino control at anv wild wall, sa well as lor cost of removal of any debris, end shall indemnity Contrator in this regard, $\$ 10,000,000.00$

14.11 Pollulion and Contamination: Notwithstanding anything to the contrary contained herein, except the provisions of Parsgraphs 10 and 12 h is understood and agreed by and between Contractor and Operator that the responsibility for poltution and contamination shall be as follows:

(a) Unless othenwize provided herein. Contractor shall assume all responsibility for, including contiol and removal of and protect, defend and ave harmless Operator from and against all claims, demands and causes of action of every kind and charaeter arising from pollution or contamination, which orioinates above the sutace of the land or water from spils of fuets. character arising from poliution or contaminalion, which orginates dope, paints, solvents, ballest. bilge and earbage. excepi unavoidable pollution from reserve pits, wholly in Contractor's possession and control and directly associated with Contractor's unavoidable pollution from

(b) Operator shall essume all responsbility lor, Including control and removal of, prolect, Gefend and save Contractor harmiess from and aceinst all claims, demands, and causes of setion of every kind and character arising from all other pollution or contaminstion which may occur during the conduct of opertions hereunder, including but not limited to, that which may result from fire, blowout, cratering seepsge or any other uncontrolied flow of oil, gas, water or other substance, es well as, ine use or disposition of oil emulsion oil base or chemically treated drilling fluids, contaminated cuttings or cavings, lost cireulation and fish recovery materials and fluids, not to exceed $\$ 10,000,000,00$

(c) In the event a third party commits on act or omission which results in pollution or contamination lor which either Contractor or Operator, for whom such party ts performing work, is held to be legally liable, the responsibillty therefor shall be considered, as between Contractor and Operator, to be the seme as th the party for whom the work was performed had performed the same and all of the obligations respecting defense, indemnity, holding harmless and limitation ol responsibility and liability. es set forth in (s) and (b) above, shatt be spesifically applied.

14.12 Consequential Damages: Nather party shall be liable to the other for spucial, indirect or consequential damages resulting from or erising out of this Contract, including, without limitation, less of profit or butiness intertuptions, however same mey be caused.

15. NO WAIVER EXCEPT IN WRITING:

It is fully understood and agreied that none of the requirements of this Contract shall be considered as walved by aliher pany unless the eame is done in writing, and then only by the persons executing this Contract, or oiner duly authorize representative of the party.

16. FORCE MAJEURE:

Nolther Operator nor Contractor shall be liable to the othar for any delays or damege or any failure to eet due, oceasiones or caused by reason of any laws, rules, regulations or orders promulgated by any Federal, Stite or Locil governmental body or the rules, regulations, or orders of any public body or officisl purporting 10 exereise authorlly or control respeeting the operations covereo hereby, including the procurance or use of tools and equipment, or due, occasioned or caused by strikes, action of the lements, water conditions, inability to obtain fuel or other critical materials, or other causes beyond the control of the party afiecled thereby. In the event that either party hereto is rendered unsble, wholly or in part, by any of these causes to cerry out its obligation under this Contract, it is agreec that, such party shall give notice and deteils of force Majeure in writing to the other party as promptly as possible efter hs occurrence. In such cases, the obligations of the party giving the notice shatl be suspended during the continuance of any insbility so caused except that Operator shall be obligated to pay to Coniractor the Force Majeure Rate provided for in Paragraph 4.7 above.

17. INFORMATION CONFIDENTIAL:

Hon wittitrectuestbJ Operato Information obtained by Contractor in the conduct of drilling operations on this well, including, but not limited to, depth. formetions penetrated, the results of coring. testing. and surveying. shall be considered confidential and shell not be divulged by Contractor or his employees, to any person, firm, or corporation oiner than Operator's desionaled representatives.

18. SUBCONTRACTS BY OPERATOR:

Operator may employ other contractors to perform any of the operatlons or services 10 be provided or pertormed by $h$ eccording to Exhibit *A.

19. ASSIGNMENT:

Nelther piny may assion this Contrset without the prior written consent of the other, and prompt notice of any such intent 10 assign shall be given to the other party. In the event of such assignment, the assioning party shall remain liable to the other party

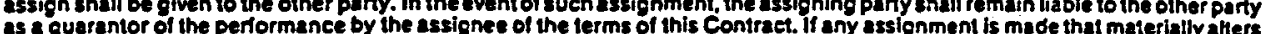
as a guarantor of the penormance by the assignes of the ferms of this contract. Tiny assignment is mide that materially ahers Coniractor's financial burder,

20. NOTICES ANO PLACE OF PAYMENT:

All notices to be given with respect to this Contraet unless ol herwise provided for shall be given to the Contraet or and to the Operator respectivaly at the addresses hereinabove shown. All sums payable hareunder to Contractor shall be payable at his oddess hereinabove shown uniess otherwise specified herein.

21. SPECIAL PROVISIONS:

21.1 Gruy Faderal, Ine.. Geperal Provistone, utth the exeept1on of Ho. 17 "Xey Personsel", are ettached hereto ade by ths refezape abe part hereof.

21.2 Additlonal Provistons st "Safety Polley". I. P. "Intellectual Property", S.C.A.

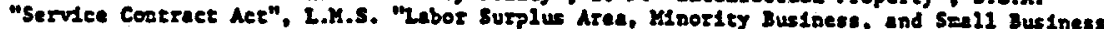
Subcontractios Prograns". P.I. "Patent Inderify", and P.R. "Patent Rights", are attached hereto and by this reforance inde a part hereof.

22. ACCEPTANCE OF CONTRACT:

The foregoing Contract is agreed to and accepled by Operator this 17th day of April 1979

OpERATOR: Gruv Federal Inc.

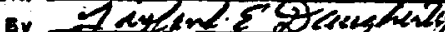

Tile VicelPresident, Floance (Gayland Daugherty)

The toregoing Contract is accepted by the undersigned as Contractor this 17 th day of April 19

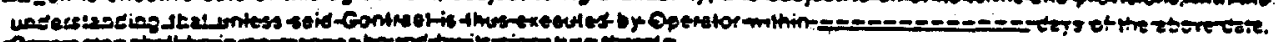

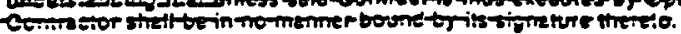

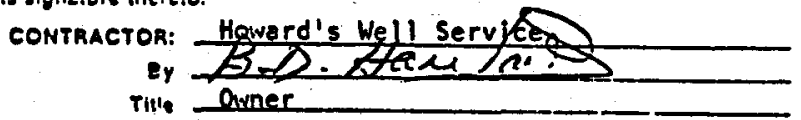

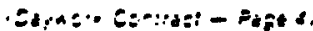


To Daywork Contract dated Apr 11

1879

Operator Gruy Federal. Inc.

Contractor Howard's Well Service

Well Name end Number St. Mary Parish Louls lena

ePECIFICATIONS AND SPECIAL PROVISIONS

1. Casing prockam (sue par. 7 ) As specified by Operator - See Exhibit 7.2 .12

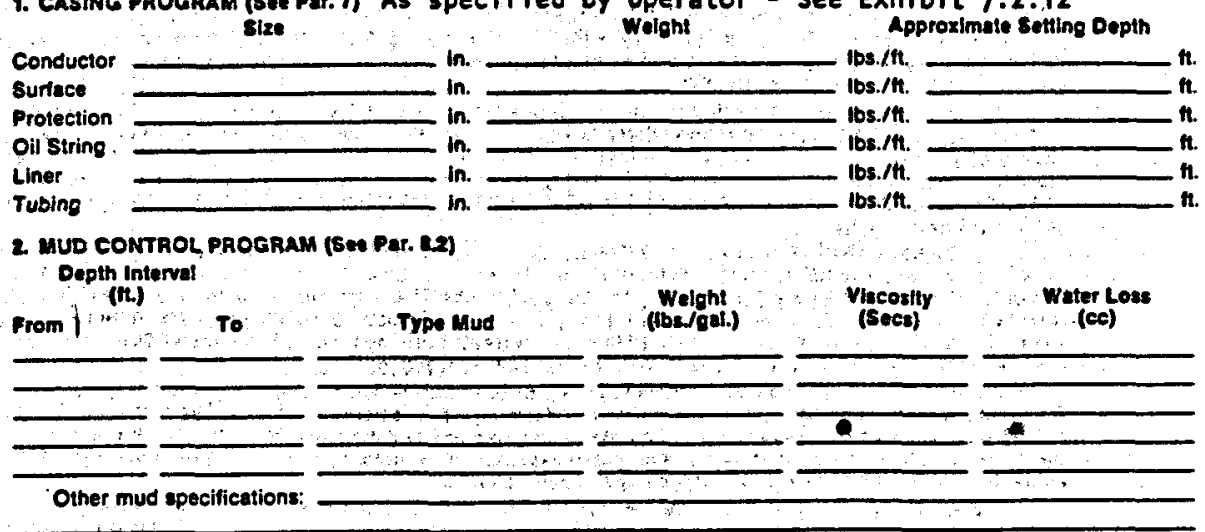

3. insuranCE (Sne par. 13) Certiflcate attached.

3.1 Adequate Workmen's Compensation insurance complying with State Laws applicable of Employers' Liabiltiy Insurance with limits of \$ covering atl of Contractor's employees working unider this agreement.

2.2 Comprehensive Public Liability Insurance or Public Llability insurance with ilmits of

death or injury of any one person and 8 - lor each accident.

as Comprehensive Public Llability Property Damage Insurance or Public Liability Property Damage insurance with limits of $\$$ for each eccident and \& uggregate per policy.

2.4 Automobile Public Liability Insurance with limits of $\$$ $5 \quad$ for each accident; and Automobile Public Liability Property Damage Inautance with Himits of $8 \ldots$. tor each eccident.

2.5 in the event operations are over water, Contractor anall carry in eddition to the Statutory Workmen's Compenzation insurance, endorsements covering lisbility under the Longshoremen's a Harbor Workers' Compensation Act and Maritime liability including maintenence and cure with limits of 8 person and \&

3.6 Other Insurance: tor any one accident.

\section{SOUPMENT, MATERIALS AND SERVICES TO BE FUANISHED GY CONTRACTOA:}

The machinery, equipment, tools, materials, supplies, instruments, services and labor herainatter listod. including any transportation required tor such llems, shall be provided at the location at the expenise of Contractor unless otherwise noted hereon.

41 Driming Rig: Inventory ettached.

Complete orilling rig. designated by Contractor as his Fig No. the major hems of equipment being: Drawworks:

(Maks and Modol)

Engines: Make, Model, and H.P.

No. on Rig

Pumps: No. 1 Make. Size, and Power

No. 2 Make, Size, and Power

Mud Mixing Pump: Make, Size, end Power

Boilers: Number, Make, H.P. end W.P.

Derrick or Mast: Make, Size, and Capacity

Substructure: Size and Capacity

Rotary Orive: Type

Drill Pipe: Size _ـ_ in

Drill Collars: Number and Size

Blowout Proventers:

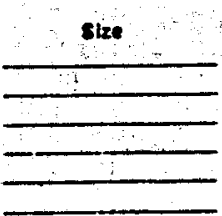

B. O. P Closing Unit

B. O. P Accumulator:

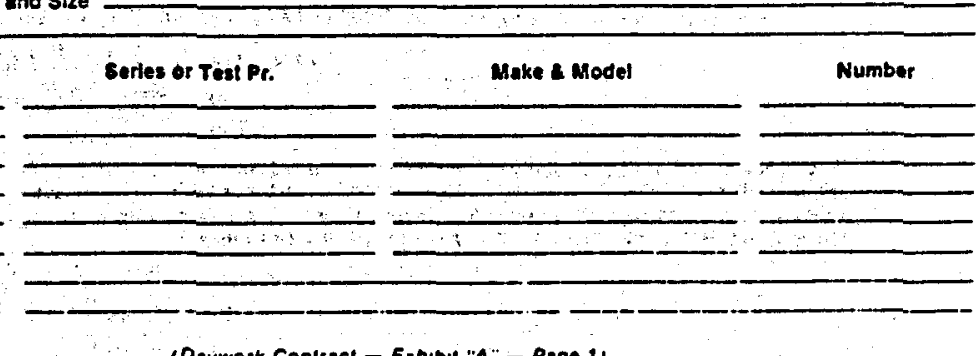

1Daywork Contract - Exhibit "A" - Page "1 
4.2 Derrick timpers.

43 Normal strinos of drill pipe and drill collars specitied above.

4.4 Conventional drift indicator.

4.5 Circulating mud pits.

4.6 Necessary pipe racks and ngoing up material.

4.7 Normal storage for mud and chemicals.

4.8 Shale Shaker.

4.8

4.10

411

4.12

4.13

4.14

4.15

4.16

4.17

6. EOUIPMENT, MATERIALE ANO SERVICES TO EE FUANISHED OY OPERATOR:

The machinery, equipment, tools, materials, wpplies, instrumems, tervices and labor herainatter listed, including any transportation required for auch items, shall be provided it the location at the expense of Operator uniess otherwise noted
hereon.

5.1 Furnish and maintsin sdequate roadway and/or cand to locatlon, right-of-way. Including rights-of-way tor fuel and water lines. fiver crossings, highway crossings, gates and cattle guards.

S2. Stake location, clear and grade location, and provide turnaround, including surfacing when necessary.

5.3 Test tanks with pipe and fittings.

5.4 Mud storege tanks with pipe and fittings.

C.5 Seperator with pipe and tittings.

B. Labor to connect and diaconnect mud tenk, test tank, and reparator.

B.7 Labor to disconnect and ctean test tanks and separator.

5.8 Drilling mud, chemicals, lost clrculation materials and other additives.

6. Pipe and connections for oll circulating lines.

8.10 Labor to lay, bury and recover ofl circulating unes.

5.11 Drilling bits, reamers, reamer cutters, stabilizers and special tools.

5.12 Contraet fishing tool carvices and tool rental.

5.13 Wire line core bits or heads and wire tine core catchers II required.

5.14 Conventionsl core bits and core catchere.

5.15 Diamond core barrel with head.

a.16 Cement and cementing rervics.

6.17 Eloctrical and Gamma-Neutron and Micro logging services.

8. IB Directional, caliper, or other spechal services.

6.19 Gun or jet pertorating services.

2.20 Explosives and thooling devices.

S.21 Formation testing. hydraulic fracturing. acidizing and other related services.

8.22 Equipment for drill stem testing.

S.23 Mud logging Eervices.

S.24 Sidewail coring service.

25 Welding service for weiding bottom foints of easing, guide shoe, flost whoe, flost coltar and in connection with intalling of well head equipment $k$ required.

26 Cesing. tubing. lines, screen, float coltars, guide and fost shoes and essociated equipment.

8.27 Cesing acratchers and centratizer.

5.26 Welf head connections and all equipment to be installad in or on well or on the premises tor wee in connection with testing, completion and operation of well.

5.20 Special or added storege for mud and chemicals.

5.30 Casinghead, API series, to conform to that thown for the blowout preventers epecilied in Paragraph 4.1 above.

5.31 Blowout preventer lesting pactott.

8.2 Casing Thread Protectors and Casing Lubricanta.

c.s3 Drilling Rate Recorder

6.34

8.35

8.36

$\mathbf{8 . 3 7}$

8.98

8.39

c.40

241

6. EOUPAENT. MATERIALS AND SERVICES TO DE FURNISHED BY DESIGNATED PARTY:

The machinery, equipment, tools, materials, supplles, instruments, services, and labor listed as the following numbered hems inctuding any transportation required for euch hems unless ofherwise specified. shall be provided at the location and at the expense of the party hereto es cestgnated by an $x$ mark in the appropriate column.

Item

6.t Cellar and runway

C.2 Fuel (located ot

Cs Fuel Lines llength

C. Water at cource, including required permits

a.s Water well, including required permits

6.6 Water lines, including required permits

67 Water storsoe tanks

6. Letor to operate wh

c. Maintenance of water well. II required

6.10 Mats for engines and boilers, or motors and mud pumps

Q.11 Transportation of Contractor's property

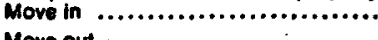

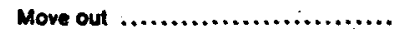

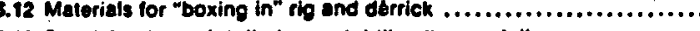

6.13 Special strings of drill pipe and drill collars as lollows:

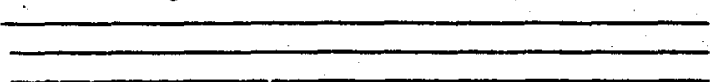

(Oaywork Contract - Eamoit "A" - Page 2)
To ae Provided ey and

As The Expense of

Operator Contractor

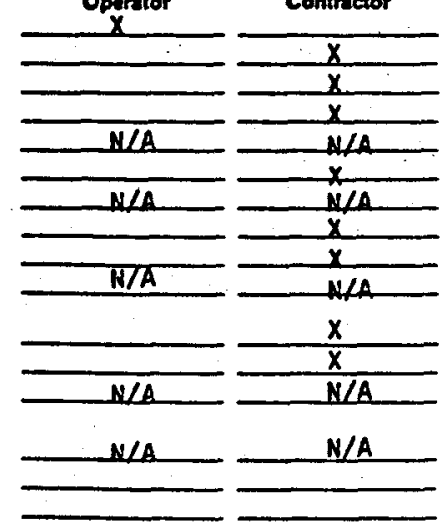


Revised Dec. 1975

Item (Continued)
To Be Provided Ey And

Al The Expense of

Operator

Contracior

$\mathbf{x}$

C.14 Kelly loints, eubs, elevators and stips for use with special drill pipe ....

C.15 Drll pipe protectors lor Kelly joint and each foint of drill pipe

running inside of Surtace Casing es required

for vee with normal strings of drill pipe

6.t6 Drlll pipe protectors lor Kelly joint and drill plpe running

inside of Protection Casing ......................................

C.17 Coring reel with wire line of eufficient length lor coring at maximum

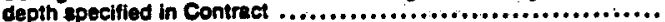

Q.18 Wire the core barrel ...

C.19 Conventional core barrel

6.20 Rate of penetration recording device

C21 Extre labor for running and cementing casing

cer casing loois. in.

C.23 Power casing tongs

6.24 Tubing tools

6.26 swabbing unit with swabbing line

6.27 swab.

628 Swab lubricator

6.29 swab rubbers

6.0 Crew Bosts, Number

C.31 Service Barge...

C.32 Service Tug Boat

6.33 Melicopter service

6.34 Rat Hole

6.25 Mouse Hole

636 Reserve Pits

6.37 Erect and Dismantle Derrick

c.38 Upper Kelly Cock

6.29 Drilling hole for or driving for conductor pipe

6.40 Charges, cost of bonds for public roads

6.41

6.42

8.43

7. OTHER PROVISIONS:

See Attachment
Signed by the Partles as correct

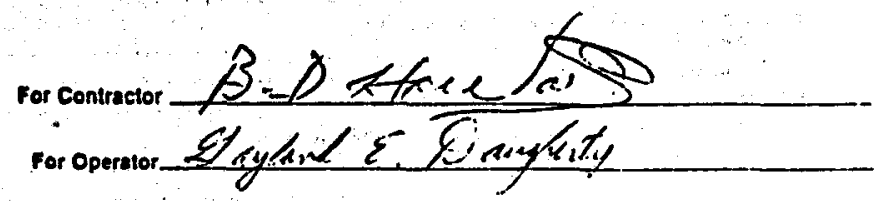

(Daywork Contract - Exhibit "A" - Page 3) 


\section{OTHER PROVISIONS:}

7.1 Termination agreement subject to Gruy Federal, Inc., Provision No. 29, ("Termination for Default or for Convenience of the Government").

7.2 Casing, cementing and logging program

Based on $\log$ information from the Neuhoff-Fairfax Foster Sutter No. 2 Well, there are three sand intervals suitable for disposal of Geo ${ }^{2}$ brines. Criteria for the selection of disposal aquifers include (1) minimum acceptable disposal depth of 3400 feet as specified by the Louisiana Department of Conservation, and (2) maximum acceptable depth as determined necessary to obtain adequate disposal sands.

Operation: 1. Drive 13-3/8" 00 PEB casing to refusal at approximately $125^{\prime}$.

2. Move in contract water well rig, unload and rig up same. Drill rat hole and mouse hole.

3. Orill 12-1/4' hole to $1200^{\prime}$ and run $1200^{\prime}$ of $9-5 / 8^{\prime \prime} 36 \mathrm{H} / \mathrm{ft}$. $H-40$ R-3 casing with guide shoe on bottom and float collar $1 \mathrm{Jt}$. above bottom. Use one centralizer per each $100^{\prime}$ of casing through bottom 500'. Use sufficient cement to circulate same to surface allowing 150 percent of annular volume.

4. Nipple up blowout preventers while waiting on cement.

5. Drill 8-3/4" diameter hole below surface casing to 4000 '.

6.' 'Run ISF-Sonic log with caliper from 4000' to 1200'.

7. Make trip with drill pipe and condition hole to 4000'. Rig up equipment preparatory to running production casing. $\mathrm{POH}$ and lay down drill pipe.

8. Run 5-1/2" 15.5 "ff J-55 R-3 casing to $4000^{\prime}$ with shoe on bottom and float collar $1 \mathrm{jt}$. above bottom. Use centralizers on every other joint from bottom to a height that will allow a minimum of two centralizers inside the 9-5/8" surface casing with sufficient cement to circulate to surface.

9. Pick up $2-7 / 8^{\prime \prime}$ work string. Condition hole to top of float collar and $\mathrm{POH}$.

10. Rig up wireline truck and run gamma-ray cement bond log from top of float collar to approximately 1000'. If bond log indicates need for cement squeeze, perforate $1-1 / 2$ ' above and $1-1 / 2^{\prime}$ below base of same for a total of $3^{\prime}$ of perforations.

11. GIH with RTTS tool and $1 \mathrm{jt}$. of tail pipe and squeeze perforations at base of objective sand. Reverse out excess cement.

12. Pull RTTS tool and tail pipe up to $30^{\prime}$ above top of injection sand. Repeat perforating procedure using through-tubing perforating gun. Proceed to squeeze perforations.

13. Make trip to lay down squeeze tool. Pick up bit and drill out cement from both block squeeze jobs. Condition mud to top of float collar.

14. Test block squeeze perforations to 1500 psi for 30 mins. If test satisfactory, displace all mud from hole with water, lay down drill pipe, remove BOP, and install wellhead. 
15. Rig down and move out rig.

16. Rig up and perforate well in interval to be selected from electric log.

17. Test injectivity of well wi th pump truck to achieve injection rate of 10,000 bbl/day at 150 psi or less. If injection rate is not sufficlent, select and perforate additional sand intervals, or consider treatment with mud cleanout acid or both if deemed necessary.

NOTES:

1. A Gruy Federal, Inc. representative will be on site to observe al) casing, cementling and logging operations.

2. If a coring operation is required our representative will be A 14 present and rig time required will be charged at the $\$ 100.00 /$ BD. hour rate, until hole is returned to pre coring condition.

7.3 Title to all services as furnished hereunder shall pass direct from Contractor to the United States Government at F.0.B. point of delivery.

7.4 Expenditures under this Contract shall not exceed $\$ 85,000.00$ without prior approval of Operator.

7.5 Contractor must advise Gruy Federal, Ine., Purchasing Department by telephone at time expenses reach $\$ 85,000.00$. Telephone: (713) 785-9200. 
1. EQUAL EMPLOYMENT OPPORTUNITY.

A. Operator is an Equal Opportunity Employer. It is agreed as a condition of this Contract that unless any or all work performed hereunder is exempt under Executive Order 11246 (30 Fed. Reg. 12319) as amended, or under the rules and regulations issued thereunder. during the performance of this Contract. the Contractor sgrees as follows:

1. The Contractor will noi disctiminate againgt any employes or applicent for employment because of race, religion, color. sex or national origin. The Contractor will take atfirmative action to ensure that applicants are employed, and thet employees are treated during employment, withoul regard to their race, religion, color, sex or national origin. Such action shafl include, but not be limited to the following: Employment, Upgrasting, demofion, or transfer; recruitment or recruitment advertising; layof or termination; rates of pay or other forms of compensation; and selection for training, including appranticeship. The contractor contracting officer setting forth the provisions of this nondiscrimination ctause.

2. The Contractor will, in all solicitations or advertisements for employees placed by or on behall of the Contractor, state that all qualified applicants will receive consideration for employment without regard to race, religion, color. sex or national origin.

3. The Contractor will send to each tabor union or representative of workers with which he has a collective bargaining agreement or other contract or understanding, a notice to be provided by the agency contracting officer, advising the labor 1965, and hall post copies of the notice in conspicuous places available to employees and applicants for employment.

4. The Contractor will comply with all provisions of Executive Order 11246 of September 24, 1965, and of the rules. regulations, and relevant orders of the Secretary of Labor.

5. The Contractor will furnish all information and reports required by Executive Order 11246 of September 24,1965 , and by the rules, regulations, and orders of the Secretary of Labor. Or pursuant thereto, and will permit access to his books, records, and accounts by the contracting agency and the Secretary of Labor for purposes of investigation to ascertain compliance with such rules, regulations, and orders.

6. In the event of the Contractor's noncompliance with the nondiscrimination clauses of this Contract or with any of such rules. regulations, or orders, this Contract may be cancelled, terminated, or suspended in whole or in part and the Coniractor may be deciared ineliglble for further Government contracts in eccordance with procedures authorized in Executive Order 11246 f

7. The Contractor will include the provisions of Paragraphs 1 through 7 in every subcontract or purchase order unless exempted by rules, regulations, or orders of Secretary of Lubor lasued pursuant to Section 204 of Executive Order 11246 of September. 24, 1965, so that such provisions will be binding upon each subcontractor or vendor. The Contractor will take such action with respect to any subcontract or purchase order as the contracting agency may direct as a maens of enforcing such provisions including sanctions for noncompliance; Provided, however, that in the event the Contractor becomes involved in, or is threatened with litigation with a subcontractor or vendor as a result of euch direction by the contracting agency, the Contractor may request the United states to enter into such litigation to protect the interests of the United States.

B. Filing Standard Form 100 (EEO-1) and Development of Attirmative Action Progran.

1. Contractor acknowledges that he may be required to file Standard Form 100 (EEO-1) promulgated jointly by the bifice of Federai Contract Compliance, the Equal Empioyment Opportunity Commission and Pians for Progress within thirty (30) days of contract award, if such report has not been filed for the current year and otherwise comply with or file such other compliance
reports as may be required under Executive Order 11246, as amended and Rules and Regulations adopted thereunder.

2 Contractor further acknowledges that he may be required to develop a written aftirmative action compliance program as required by the Rules and Regulations approved by the Secretary of Labor under authority of Executive Order 11246 and supply
Operator with a copy of such program If Operator so requests.

\section{Monsegregated Facilities.}

Contractor certifies that he does not maintain of provide for his omployees any segregated facilities at any of his establishments, and that he does not permit his employees to pertorm their eervices al any location, under his controi, where segregated facilities are maintained. He cartifies further that he will not maintain or provide for his employees any segregated fecilities at any of his establishments, and that he will not permit his employees to perform their services at any location, under his control, where segregated facilities are maintained. Contractor agrees that a breach of his certification is a violation of the Equal Opportunity Cleuse in this Contrect. As used in this certification, the term "eegregated lacilities" means any waiting rooms, work areas, rest rooms and wash rooms, restaurants and other eating areas, lime clocks, locker rooms and other atorage or dressing areas. parking lots, drinking fountsins, recreation or entertainment areas, transportation and housing facilities provided for employees which are segregated by explicit directive or are in fact segregated on the basis of race. color, religion, sex, ego or national origin, because of habit, local custom or otherwise; Contractor's policies and practices must assure appropriate physical tacilities to both sexes. He further agrees that (except where he has obtained identical certifleations from proposed subcontractors for specific time periods) he will obtain identical certifications from proposed subcontractors prior to the award of subcontracts oxceeding \$10,000 which ere not exempt from the provisions of Equal Oppontunity Clause; that he will retaln such certfications in his flles; and that he will forward the following nolice to such proposed subcontractors (except where the proposed wbcontractors have submitted identical certifications for speciffe time periods): "NOTICE TO Certification of Secretary of Labor (33 Fed. Reg. 7804, May 28, 1968), must be subritted prior to the award of a subcontract exceeding 510,000 which is not exempt from the provisions of the Equal Opportunity Clause. The certilication may be submitted elther for each subcontract or for all subcontracts during e period (1.e., quarterly, semiannually, or annually)."

\section{Penatites}

Contractor further understands and agrees that a breach of the assurance contained in Paragraphe $A$ through $C$ above aubjects it to the provisions of the Order at 41 CFR Chapter 60 of the Secretary of Labor dated May 21, 1968. In the event of Contractor's noncompliance with the nondiserimination clauses of this Contract of with any of such rules, regulations, of orders, such noncompliance onall constitute sufficient grounds, and the parties hereto agree to immediate cancellation of this Contraet on the basit of euch noncompliance with no further obtigation whatsoover on the part of the Operator.

\section{LISTING OF EMPLOYMENT OPENINGS}

The undersigned Contractor further aprees, It the vajue of any contract or purchase order is $\$ 2,500$ or more, that if will be bound by the following provisions contained in 41 CFR $50-250$ promulgated pursuant to Executive Order No. 11701:

A. The Coniractor, to provide specide iemphasis to the employment of qualitied disabled veterans and veterans of the Vietnam era, egrees that all suiteble employment openings of the Coniractor which exist at the time of the execution of this Contract and those which occur during the performance of this Contrect. including those not generated by this Contract and including those the occurring at an establishment of the Contractor oiner then the one wherein the Contract is being performed but excluding those of independently operated corporate aftiliates, shall be offered for histing at an appropriate local office of the State employment cervice system wherein the opening occurs and to provide such reports to such local office regarding employment openings and

hires es may be required; Provided. That this proviston ahall not apply to openings which the Contractor fills from within the
Contractor's organization or are filied pursuant to e customary and iraditional employer-union hiring arrangement.
b. Listing of employment openings with the employment service system pursuant to this clause ahall be made at least concurrently with the use of any other recruitment service or effort and shall involve the normal obligations which sttech to the placing of a bonafide job order, including the acceptance of relerrals of veterans and nonveterans. The listing of employmen openings toes not require the hiring of any particular job applicent or from any particular group of job applicants, and nothing herein is intended to relieve the Contractor from any requirements in any Executive Orders or regulations regarding nondiscrimination in employment. 
August 23, 1979

Mr. Richard J. Dobson

Vice President - Operations

GRUY FEDERAL, INC.

2500 Tanglewilde, Suite 150

Houston, Texas 77063

Dear Mr. Dobson:

At the request of $\mathrm{Mr}$. Tausch and Mr. Pearce, I an replying to your letter of August 2, 1979.

Attached for your reference are reports from Gary Brunk, CAMCO Location Manager, who was on the Job and Gary Corbell, CAMCO's Gulf Coast Conductor Line Manager.

As you see from these reports, all equipment has been completely checked out and with the exception of one HewlettPackard probe, everything tested satisfactorily. The cable head was also re-wired without eliminating the problem. We are currently using the same equipment in other areas and have not experienced any other problems of this nature. Subsequent conversations with other CAMCO operating areas have resulted in no additional insight as to what may have caused the problem even though similar difficulties have been encountered.

As seen in the reports. Hewlett-Packard also has been unable to shed any light as to the cause. We regret the difficulties experienced and 1 want to assure you we have looked into every aspect as to what could have caused the problem. We will be most willing to conduct any further tests you may wish. 
Mr. Richard J. Dobson

Vice President - Operations

GRUY FEDERAL, INC.

August 23, 1979

Page Two

Please let us know if there are any questions or if we can be of further service.

Yours very truly,

CAMCO, INCORPORATED

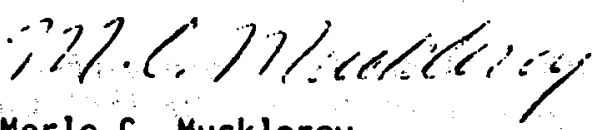

Merle C. Muckleroy

Vice President

Western Hemisphere Sales

$\mathrm{MCM} / \mathrm{sm}$

At tachments

cc: Mr. G. H. Tausch

Mr. S. W. Pearce 
SUEJECT GRUY FEDERAL - FAIRFAX, FOSTER, SUT IER LEASE - WELL

To M. MUCKLEROY

DEP'T DOMESTIC SAIES

From G. CORBELL DEP'T ELECTRIC LINE

Please find attached, a job report as prepared by Gary Brunk immediately after the job mentioned above.

The following procedures were completed in an attempt to determine the reason for non-completion of this job.

A. Tool \$256 was found inoperable and is now at H/P for repair.

B. Tools \#111 and $\$ 212$ were placed in a dry temperature bath at CAACO and run up to $280^{\circ} \mathrm{F}$. Neither tool failed. (These two tools did not record at $240^{\circ}-250^{\circ} \mathrm{F}$. in the well).

C. A 500 volt megger was applied to the line, but line Insulation proved good.

D. All tools and line are now bein! used in Wyoming and have not had a fallure yet. The approximate operating rances are $1000 \mathrm{PSI}$ and $180^{\circ} \mathrm{F} .-220^{\circ} \mathrm{F}$.

Therefore, I have not been able to deteri ine reason for problem.

I should mention, I once ran a tool in tle North Sea fur B.P. which did exartly the same thing. (However, at lower pressure and temperature.) The tool was. run on Schlumberger line and they reported no line problems and we could find no tool problems in the shop.

Also, Dr. Sam swift indicated Cities Services had had ihe same problem and has not been explained satisfactorily by anyone including $H / P$.

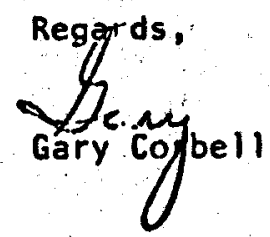

$\mathrm{GC} / \mathrm{jt}$

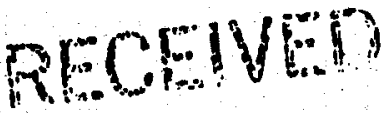

AUO 191979

DOMESTICSA! S: 


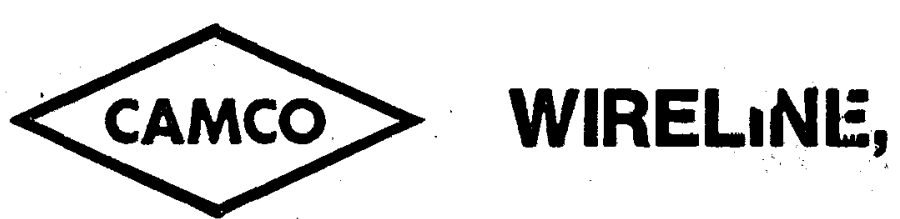


Junè 12, 1979

Page 2

dwindled down to $15 \mathrm{M} / \mathrm{V}$. I pulled out of the hole and checked all the sinker bars and found no leakage or interminterit type of prohlems. Gruy Federal said to rig equipment down. I rigged down with the line always showing good capacitance $k i c k$ and no leakage.

End of job 5-26-79.

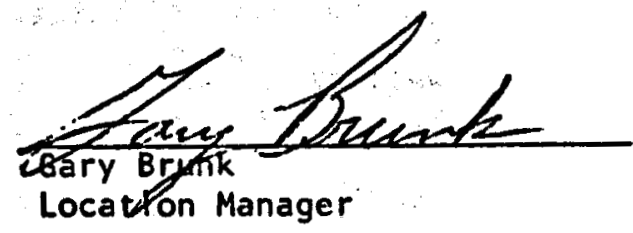

GB/jt

cc: A. McNabb, Division Manager, Camco Wireline, Inc. Jim Hartsock, Gruy Federal, Inc. 


\section{APPENDIX D}

Transient flow phenomena have been investigated by many authors ${ }^{11-20}$ and mathematical models of reservoirs producing under unsteady-state flow conditions have been presented in many publications. In 1949 A. F. van Everdingen and William Hurst published "The Application of the Laplace Transform to Flow Problems in Reservoirs." 21 In this classical study the authors defined the pressure and production behavior of the single-phase flow of incompressible (or slightly compressible) Newtonian fluids in infinite and finite circular reservoirs. Their assumptions included homogeneity and 1sotropy of the porous formation as well as laminar flow and Darcy's Law.

These authors presented the solution of their flow equations in terms of a dimensionless unit rate of flow and a dimensionless unit pressure drop. Inherent in the solution was the required constancy of elther flow rate or pressure drop, both of which are restrictive assumptions during the exploitation of underground reservoirs. To account for variations in flow rate (or pressure) they used the superposition theorem, which states that, for homogeneous and linear partial differential equations, if $U_{1}, U_{2}, U_{3}$, . . $U_{n}$ are particular solutions of a differential equation, then $C_{1} U_{1}+C_{2} U_{2}+C_{3} U_{3}+\ldots+C_{n} U_{n}$ is a general solution, where the $C_{i}$ 's are constants.

For single-well problems, the constant terminal rate case presented by van Everdingen and Hurst is the most useful. Their fundamental equation under these conditions with constant flow rate $q$ is:

$$
p_{i}-p_{w f}=2 m p_{D}
$$

where $\quad m=\frac{q \mu}{4 \pi k h} \cdot \quad$ (NOTE: all symbols are defined
at the end of this Appendix.)

However, if the flow rate is variable, application of the principle of superposition gives:

$$
p_{i}-p_{w f}=2 m \sum_{j=1}^{n} \Delta q_{j} p_{D_{j}}
$$


where $P D_{j}$ represents the dimensionless pressure drop associated with change in flow rate $\Delta q_{j}$, 1.e., $q_{j}-q_{j-1}$.

Now the function $p_{D}$ is defined as

$$
p_{D}=\frac{4}{\pi^{2}} \int_{0}^{\infty} \frac{\left(1-e^{-U^{2} t_{D}}\right) d U}{U^{3}\left[J_{1}^{2}(U)+Y_{1}^{2}(U)\right]}
$$

where $t_{D}=\frac{k t}{\phi \mu c t^{2} w^{2}}$

Eq. $D-4$ is a complex equation, but fortunately in the study of well behavior (except for extremely short times) the $p_{D}$ function can be approximated by a. much simpler formulation for an infinite-acting reservoir:

$$
\text { for } \begin{aligned}
t_{D} & >100 \\
p_{D} & =\frac{1}{2}\left(\ln t_{D}+0.80908\right)
\end{aligned}
$$

Eq. D-1 describes the pressure drawdown of a well where the surrounding formation is neither damaged nor 1mproved. If a condition of wellbore damage or improvement exists, the equation must be corrected for these effects. Normally such a zone is limited In radius, and the name "skin" was adopted by the authors. Using the refinement suggested by van Everdingen ${ }^{22}$, eqs. D-1 and D-2 become, respectively,

$$
p_{i}-p_{w f}=2 m\left(p_{D}+\varepsilon\right)
$$

and $\quad p_{i}-p_{w f}=2 m \sum_{j=1}^{n} \Delta q_{j}\left(p_{p_{j}}+\varepsilon\right)$.

Substituting the value of $p_{D}$ defined by eq. $D-6$ gives

$$
p_{i}-p_{w f}=2 m \sum_{j=1}^{n} \Delta q_{j}\left[\frac{1}{2}\left(\ln t_{D_{j}}+0.80908\right)+8\right],
$$

where $t_{D_{j}}$ is dimensionless time

$$
\text { for } t=t_{n}-t_{j}
$$


Now, substituting the value of $t_{D}$ as defined by eq. D-5, we have

$$
p_{i}-p_{w f}=m \sum_{j=1}^{n} \Delta q_{j}\left[\ln \left(t_{n}-t_{j}\right)+\ln \frac{k}{\phi \mu c_{t} w^{2}}+0.80908+28\right] \text {. }
$$

Subsequent authors have studied the effects of varying the primary assumptions, including changes in reservoir geometry caused by the presence of impermeable barriers, the effect of compressible fluids, formation heterogeneities both natural and induced, anisotropic reservolr conditions, and non-Darcy flow.

For water flow in geopressured reservoirs, and in particular for the reservoir surrounding the Falrfax Foster Sutter No. 2, the only noticeable deviation from the original theory is the presence of linear barriers to flow.

For circular reservolrs with Iinear barrlers, eq. D-1 takes the form

$$
p_{i}-p_{w f}=2 m^{\prime} p_{D}
$$

where

$$
m^{\prime}=\frac{\mu}{4 \pi k h \theta} .
$$

If we define $\quad B=\ln \frac{k}{\phi \mu c t^{2} w^{2}}+0.80908+2 s$,

then $\quad p_{i}-p_{w f}=m^{\prime} \sum_{j=1}^{n} \Delta q_{j}\left[\ln \left(t_{n}-t_{j}\right)+B\right]$,

or $\quad p_{i}-p_{w f}=m^{\prime} \sum_{j=1}^{n}\left(q_{j}-q_{j-1}\right) \ln \left(t_{n}-t_{j}\right)+m^{\prime} B \sum_{j=1}^{n}\left(q_{j}-q_{j-1}\right)$,

which reduces to

$$
p_{i}-p_{w f}=m^{\prime} \sum_{j=1}^{n}\left(q_{j}-q_{j-1}\right) \ln \left(t_{n}-t_{j}\right)+m^{\prime} B q_{n}
$$

since $\sum_{j=1}^{n}\left(q_{j}-q_{j-1}\right)=q_{n}$ because $q_{0}=0$. 
Now, letting $\quad x_{n}=\sum_{j=1}^{n}\left[\left(q_{j}-q_{j-1}\right) \ln \left(t_{n}-t_{j}\right)\right]$, eq. D-16 ylelds

$$
p_{i}-p_{w f}=m^{\prime} X_{n}+m^{\prime} B q_{n}
$$

or $\quad \frac{p_{i}-p_{w f}}{q_{n}}=\frac{m^{\prime} x_{n}}{q_{n}}+m^{\prime} B$.

This equation represents a straight line when $\frac{p_{i}-p_{w f}}{q_{n}}$ is plotted against $\frac{X_{n}}{q_{n}}$ in Cartesian coordinates.

The intercept of the straight Iine at $X_{n}=0$ is $m^{\prime} B$ and the slope is $m^{\prime}$. It is important to note that $q_{n}$ is the last rate that can affect the pressure.

During buildup, the last flow rate, $q_{n}$, is zero; so we have

$$
p_{i}-p_{w f}=m^{\prime} x_{n}
$$

or $\quad p_{w s}=p_{i}-m^{\prime} x_{n}$

This equation also represents a straight 11ne, with slope equal to $m$ ! and intercept at $X_{n}=p_{i}$, when $p_{w s}$ is plotted against $X_{n}$ in Cartesian coordinates.

From the above equations, it is clear that the slope $m^{\prime}$ can be obtained from elther a bufldup or a drawdown, but $p_{i}$ can be obtalned only from a bulldup test, since it is required for the analysis of the flow test. However, in the case of finite reservolrs, $p_{i}$ obtained from bulldup is called apparent Inftial pressure, $p^{*}$.

The efficiency of the completion is a function of the magnitude of the skin. In order to obtain this quantity, it is necessary to determine the constant $B$, which appears only in flow equations. Even though skin does not appear in the bufldup equation, it is possible to develop a buildup equation with skin in 1 , as follows. 
If $p_{w f(\Delta t=0)}$ is the final flowing pressure at the time the well is shut in (see Fig. $D-1)$,

$$
\left.p_{i}-p_{w f(\Delta t=0)}=m^{\prime} X_{n\left(t_{n}\right.}=t_{N}\right)+m^{\prime} B q_{n}
$$

During the bufldup,

$$
\left.p_{i}-p_{w s}=m^{\prime} X_{n\left(t_{n}\right.}=t_{N}+\Delta t\right)
$$

Subtracting $D-21$ from $D-20$,

$$
\left.\left.p_{w s}-p_{w f(\Delta t=0)}=m^{\prime} X_{n\left(t_{n}\right.}=t_{N}\right)+m^{\prime} B q_{n}-m^{\prime} X_{n\left(t_{n}\right.}=t_{N}+\Delta t\right)
$$

or

$$
\left.p_{w s}=p_{w f(\Delta t=0)}+m^{\prime} X_{n\left(t_{n}=t_{N}\right)}+m^{\prime} B q_{n}-m^{\prime} X_{n\left(t_{n}\right.}=t_{N}+\Delta t\right) \cdot
$$

Now, let $Y=p_{w f(\Delta t=0)}+m^{\prime} X_{n\left(t_{n}=t_{N}\right)}+m^{\prime} B q_{n}$;

then $\left.\quad p_{w s}=-m^{\prime} X_{n\left(t_{n}\right.}=t_{N}+\Delta t\right)+Y$

This equation will yleld a straight line when $p_{w s}$ is plotted against $\left.X_{n\left(t_{n}\right.}=t_{N}+\Delta t\right)$ with a slope of $-m^{\prime}$ and an intercept of $Y=p^{*}$.

On rearrangement,

$$
B=\frac{p^{*}-p_{w f(\Delta t=0)}-m^{\prime} x_{n\left(t_{n}-t_{N}\right)}}{m^{\prime} q_{N}} .
$$

All the preceding equations infer that the reservoir is infinite-acting and radial in shape except for the $\theta$ in the $m^{\prime}$ constant. If the reservoir is not radial, $\theta$ must be known or determined. The extrapolated pressure $p^{*}$ would represent $p_{i}$ in an infinite system during the latter portion of the buildup, but If barriers exist, $p^{*}$ is a translated intercept dependent upon the shape and distance of the barriers. 
FIGURE D-1

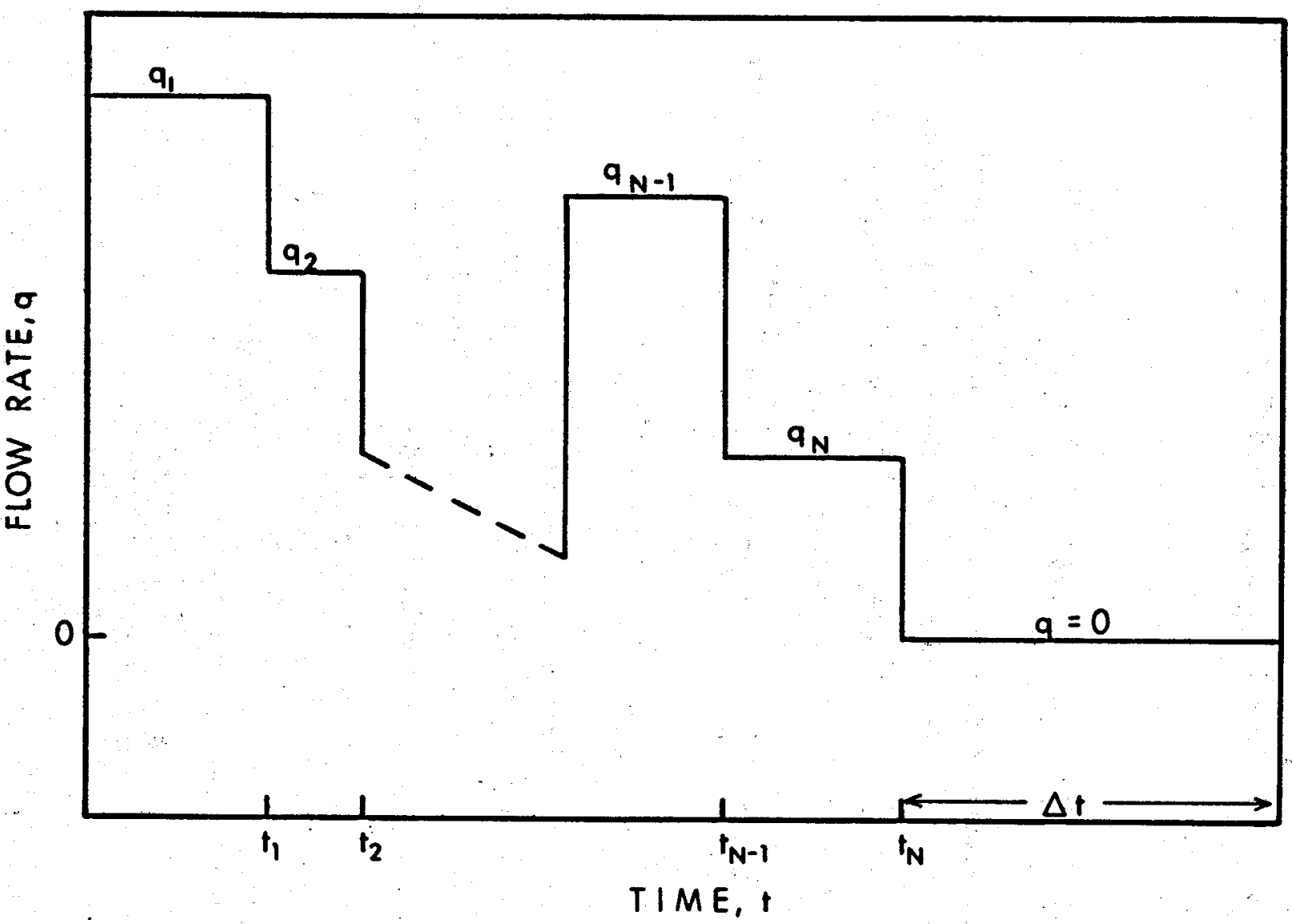

SCHEMATIC OF RATE VARIATION PRECEDING A PRESSURE BUILDUP TEST 
In the presence of a linear barrier to flow, the buildup equation must be adjusted by the method of images to

$$
p^{*}-p_{w s}=m^{\prime}\left\{X_{n\left(t_{n}=t_{N}+\Delta t\right)}-q_{N} E i\left(-\frac{\phi \mu c t d^{2}}{k \Delta t}\right)\right\}
$$

This equation can be broken into two parts:

$$
p_{w s}=p^{*}-m^{\prime} X_{n\left(t_{n}=t_{N}+\Delta t\right)}+m^{\prime} q_{N} E i\left(-\frac{\phi \mu^{c t} d^{2}}{k \Delta t}\right)
$$

The first two terms can be recognized as the pressure determined by the straightline portion of the buildup curve before the barrier is reached, 1.e.;

$$
\left.p_{s Z}=p^{*}-m^{\prime} X_{n\left(t_{n}\right.}=t_{N}+\Delta t\right)
$$

then,

$$
\frac{p_{w s}-p_{s Z}}{m^{\prime} q_{N}}=E i\left(-\frac{\phi \mu^{c} t d^{2}}{k \Delta t}\right)
$$

Therefore the Ei (exponential integral) can be computed directly from the buildup curve and the final flow data. The argument of the $E i$ can be found by use of a table or can be approximated by an iterative Newton-Raphson procedure to solve for $d$, the distance to the 1inear barrier.

$$
\begin{aligned}
-E i(-x) & =-\gamma-\ln x-\sum_{n=1}^{\infty} \frac{(-x)^{n}}{n n !}, \text { where }|\arg x|<\pi \\
f(x) & =E i(-x)-\gamma-\ln x-\sum_{n=1}^{\infty} \frac{(-x)^{n}}{n n !} \\
f^{\prime}(x) & =-\frac{1}{x}+1-\sum_{n=2}^{\infty} \frac{(-x)^{n-1}}{n !} \\
x_{\text {new }} & =x_{\text {old }}-\frac{f(x)}{f^{\prime}(x)}
\end{aligned}
$$

The solution of these equations for $x$ seemed satisfactory and converged with the use of $n=11$. 
All of the above equations use the cgs system. The major equations for solution using normal oil-field units are:

$$
\begin{aligned}
m^{\prime} & =\frac{70.6}{k h \theta}, \\
B & =\ln \frac{k}{\phi \mu c_{t^{2}{ }^{2}}}-7.432+2 s, \text { and } \\
\frac{p_{w s}-p_{s l}}{m^{\prime} q_{N}} & =-E i\left(-\frac{\phi \mu c_{t} d^{2}}{0.0002637 k \Delta t}\right)
\end{aligned}
$$




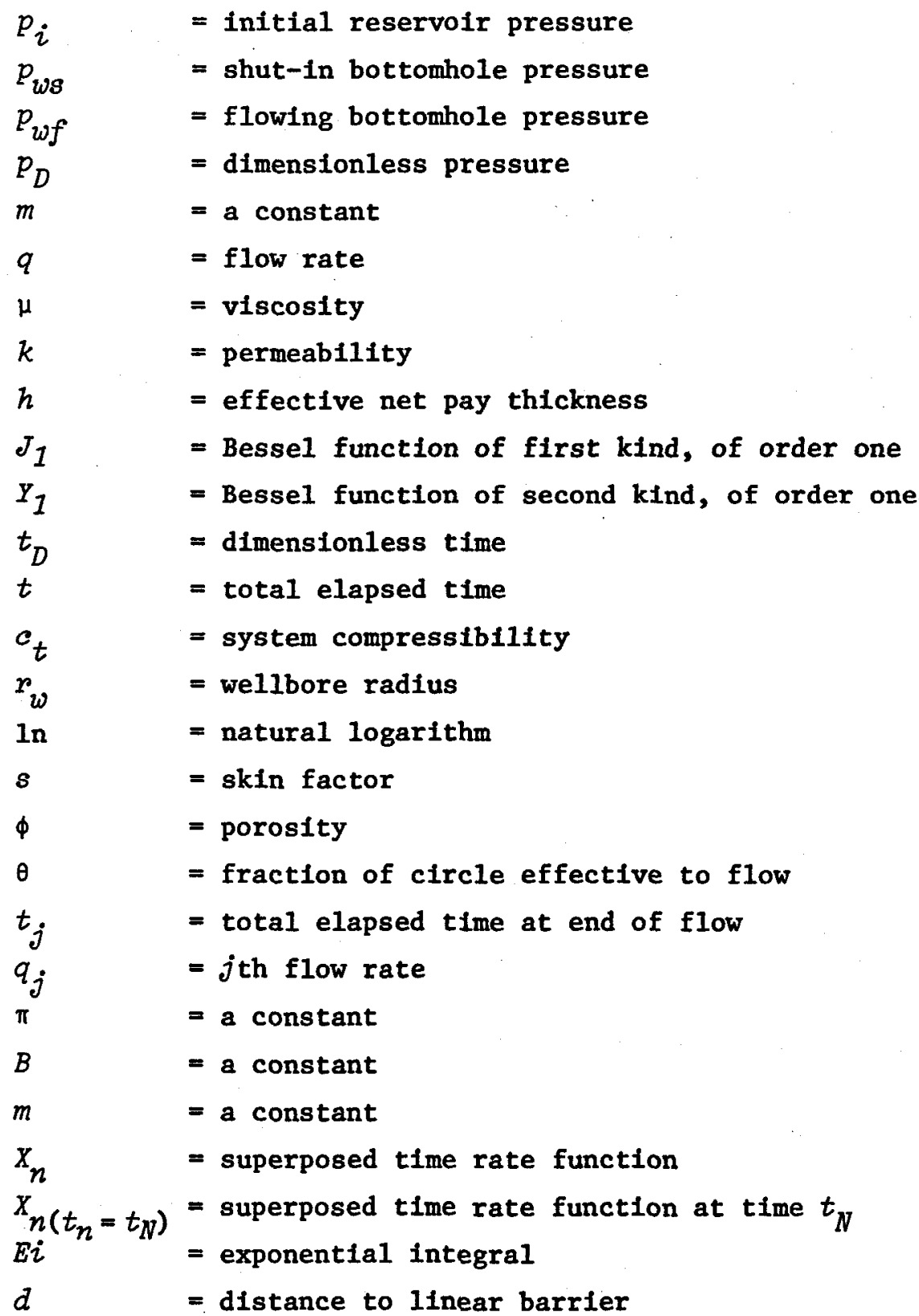

